US Army Corps

of Engineers ${ }_{\circledast}$

Engineer Research and

Development Center

Regional Sediment Management (RSM) Program

Sediment Budget for the North Illinois Shore from the Wisconsin Border to Wilmette Harbor

Andrew Morang, Lauren M. Dunkin, David F. Bucaro,

August 2019

John A. Wethington, Michael J. Chrzastowski,

and Ethan J. Theuerkauf

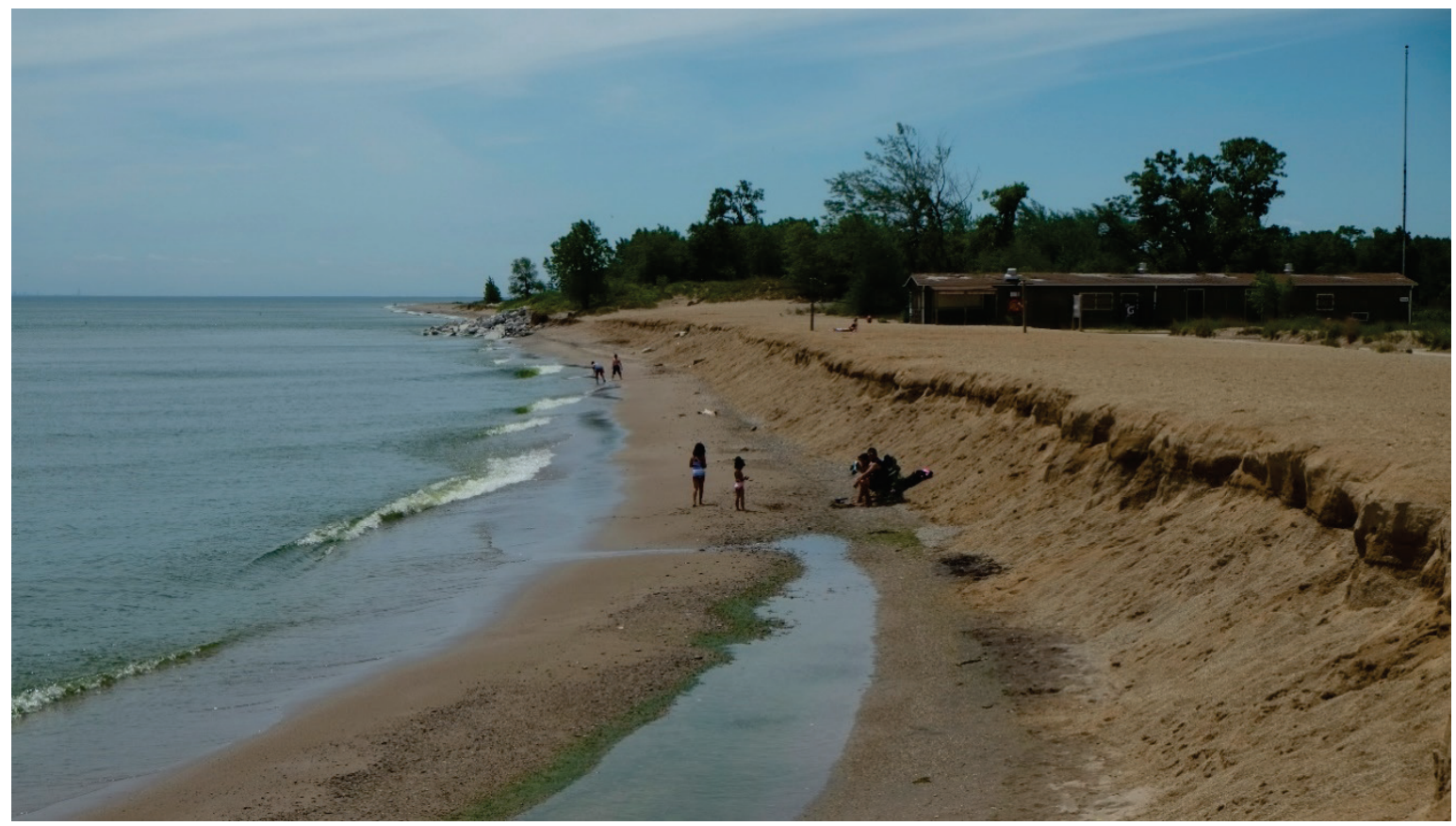


The U.S. Army Engineer Research and Development Center (ERDC) solves the nation's toughest engineering and environmental challenges. ERDC develops innovative solutions in civil and military engineering, geospatial sciences, water resources, and environmental sciences for the Army, the Department of Defense, civilian agencies, and our nation's public good. Find out more at www.erdc.usace.army.mil.

To search for other technical reports published by ERDC, visit the ERDC online library at http://acwc.sdp.sirsi.net/client/default. 


\section{Sediment Budget for the North Illinois Shore from the Wisconsin Border to Wilmette Harbor}

Andrew Morang and Lauren M. Dunkin

Coastal and Hydraulics Laboratory

U.S. Army Engineer Research and Development Center

3909 Halls Ferry Road

Vicksburg, MS 39180-6199

David F. Bucaro and John A. Wethington

U.S. Army Engineer District, Chicago

111 North Canal Street

Chicago, IL 60606-7206

Michael J. Chrzastowski and Ethan J. Theuerkauf

Illinois State Geological Survey

615 East Peabody Drive

Champaign, IL 61820-6918

Final report

Approved for public release; distribution is unlimited.

Prepared for U.S. Army Corps of Engineers

Washington, DC 20314-1000

Under Funding Account Code U4362913; AMSCO Code 008303 


\section{Abstract}

A sediment budget for the North Illinois Shore was developed to evaluate littoral processes and provide a regional sand management decision support tool. This study time frame covers the 1990 s to 2017. The North Shore of Illinois is a highly dynamic and diverse coastline with littoral processes complicated by coastal infrastructure, commercial harbors, and uncoordinated shoreline management. Longshore sediment transport along the North Illinois Shore is predominately from north to south, and the volume in the system varies greatly. The best available data were used for the computations in this sediment budget. However, some fluxes had to be inferred (i.e., from dredging records), and some were not considered (i.e., aeolian transport, offshore flux).

DISCLAIMER: The contents of this report are not to be used for advertising, publication, or promotional purposes. Citation of trade names does not constitute an official endorsement or approval of the use of such commercial products. All product names and trademarks cited are the property of their respective owners. The findings of this report are not to be construed as an official Department of the Army position unless so designated by other authorized documents. 


\section{Contents}

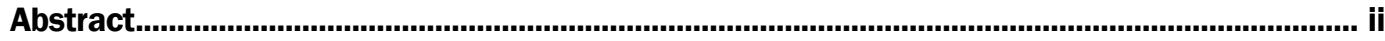

Figures and Tables....................................................................................................................................

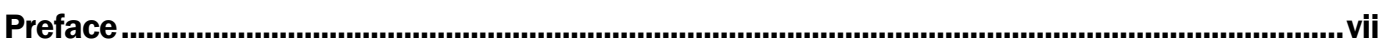

1 Introduction............................................................................................................................. 1

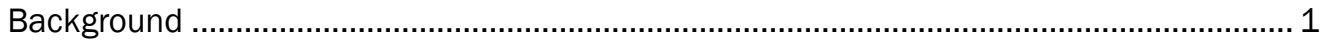

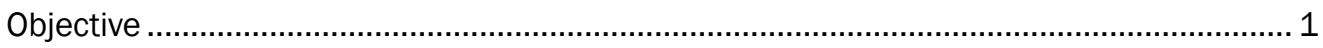

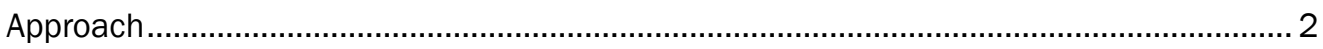

2 Study Area and Physical Processes ...................................................................................... 3

Setting and management issues .............................................................................. 3

Sediments and littoral transport ............................................................................ 6

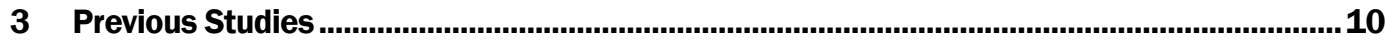

4 Data Sources, Management, and Organization ...........................................................11

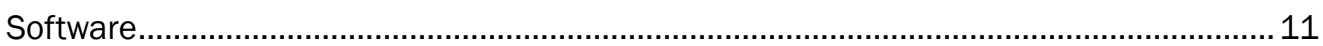

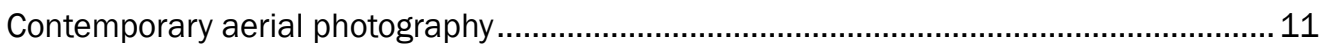

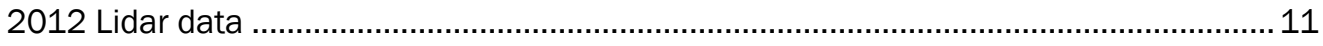

Nearshore bathymetry mid-1970s ............................................................................ 15

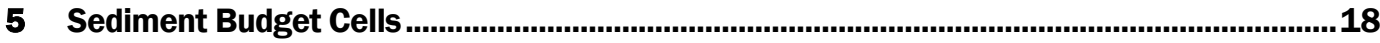

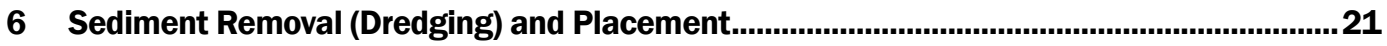

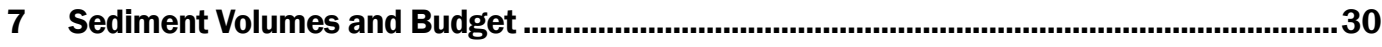

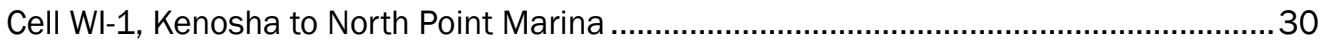

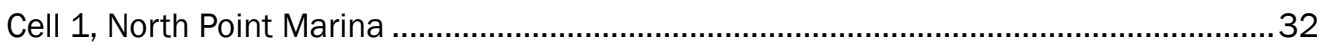

Cell 2, Illinois Beach State Park north zone .......................................................................33

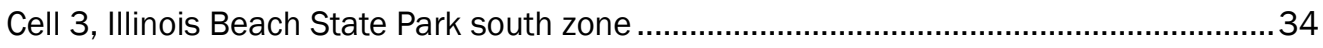

Cell 4, Waukegan Electric Generating Station intake canal ............................................34

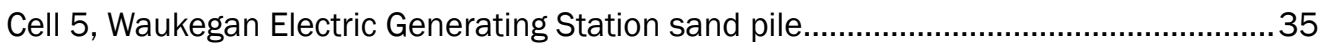

Cell 6, Waukegan Electric Generating Station to Waukegan north fillet beach..................38

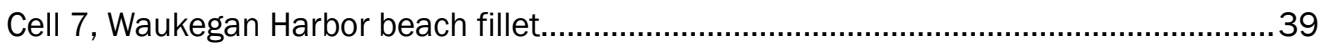

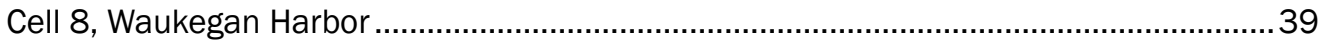

Cell 9, Waukegan to U.S. Naval Station Great Lakes north fillet ....................................40

Cell 10, U.S. Naval Station Great Lakes fillet............................................................ 41

Cell 11, U.S. Naval Station Great Lakes Harbor ............................................................43

Cell 12, U.S. Naval Station Great Lakes to Forest Park................................................45

Cell 13, Forest Park Beach .......................................................................................... 45

Cell 14, Forest Park to Winnetka water plant ...................................................................46

Cell 15, Winnetka water plant to Gillson Park ............................................................48

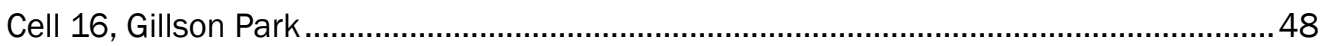


Cell 17, Wilmette Harbor and beach 48

Cell 18, Wilmette Harbor to Northwestern University

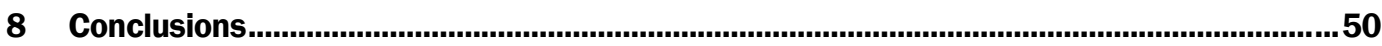

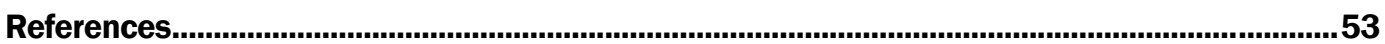

Appendix A: Data Used for Computing 1970s-2017 Sediment Budget ........................................56

Appendix B: Elevation and Volume Change for Northern Illinois Coastline, 2008-2012 ............67

Unit Conversion Factors..................................................................................................................72

Report Documentation Page 


\section{Figures and Tables}

\section{Figures}

Figure 1. Study area, northern Illinois shore of Lake Michigan. Red outlines show sediment budget cells used in this analysis. (Cell WI-1 from Kenosha, WI, to North Point Marina was not used in this analysis.) Background map from ESRI Maps and Data...

Figure 2. Borings at Fort Sheridan, IL, showing the preponderance of clay in the till bluffs. Numbers represent the boring identification and total boring depth. Photo by ESRI Maps and Data.

Figure 3. Borings at Rosewood Beach in Highland Park, IL. Clay is the predominant material at most sites, although boring B-2 (50 ft long) contained close to $25 \%$ sand. The average percent of sand for the core borings was approximately 5\%. Photo by ESRI Maps and Data.

Figure 4. Elevation contours derived from lidar data collected in 2012 compared with historical bluff edge points from ISGS, Highland Park, IL. Closely spaced contours indicate steep bluffs or ravines. Photo by ESRI Maps and Data.

Figure 5. Nearshore bathymetry from 2012 lidar data, gridded at $10 \mathrm{ft} \times 10 \mathrm{ft}$ cell size. Background map from ESRI Maps and Data.

Figure 6. Map frames 10 and 11 from ISGS 1988 Illinois coastal atlas. Isobaths were based on surveys completed during 1974-1976, adjusted to a hypothetical lake level of $581.0 \mathrm{ft} \mathrm{IGLD} \mathrm{1955.} \mathrm{Background} \mathrm{map} \mathrm{from} \mathrm{ESRI} \mathrm{Maps} \mathrm{and} \mathrm{Data.}$

Figure 7. Lakebed comparison between mid-1970s acoustic and 2012 lidar bathymetry. Contours were traced from the ISGS coastal atlas (1988 publication date but containing 1974-1976 data). Background map from ESRI Maps and Data.

Figure 8. Sediment budget north zone, from the WI-IL border to Waukegan Harbor. All units in $\mathrm{yd}^{3} / \mathrm{year} ; \Delta \mathrm{V}=$ net change in volume within the cell; $\mathrm{R}=$ amount of material removed from the cell, usually by dredging; $P=$ amount of material placed in the cell. Details of the Waukegan area are shown in Figure 13. Background map from ESRI Maps and Data

Figure 9. Sand dredged from the entrance channel at North Point Marina is piled south of the entrance and pushed into the lake. Photograph 17 June 2014.

Figure 10. Illinois Beach State Park, with scarp formed by storm waves. Photograph 17 June 2014

Figure 11. Sand pile at Waukegan Generating Station. Photograph 17 June 2014.

Figure 12. Dredged sand pile at Waukegan Generating Station. Top of the pile is unvegetated.

Figure 13. Sediment movement near Waukegan Generating Station and Waukegan Harbor. All units in $\mathrm{yd}^{3} /$ year; $\Delta V=$ net change in volume within the cell; $R=$ amount of material removed from the cell, usually by dredging; $P=$ amount of material placed in the cell. Background map from ESRI Maps and Data.

Figure 14. Historical bluff edges north of Waukegan Harbor based on ISGS data. The blue points are a hypothetical 1987 beach shoreline.

Figure 15. Waukegan Harbor north breakwater, view looking east. Shallow lakebed on the north side of the pier is demonstrated by the bathers standing in shallow water left of the structure. Photograph 17 June 2014. 
Figure 16. Elevation changes 1974/1975 - 2012 on the lakebed south of Waukegan harbor. The green plume extending south from the harbor mouth represents sand bypassing (outlined in purple). The placement site for material dredged from Waukegan Harbor is represented by the black hatched box south of the sand bypassing plume.

Figure 17. North Illinois sediment budget, central section, from Waukegan to Fort Sheridan. All units in $\mathrm{yd}^{3} /$ year; $\Delta V=$ net change in volume within the cell; $\mathrm{R}=$ amount of material removed from the cell, usually by dredging; $P=$ amount of material placed in the cell. Background map from ESRI Maps and Data..

Figure 18. Painting of U.S. Naval Station Great Lakes, circa pre-1923 (photographed from display prepared by Illinois Work Projects Administration, War Services). The present outer jetties are not shown in this painting. The north breakwater now extends out from the shore at approximately the power station.

Figure 19. U.S. Naval Station Great Lakes, oblique view from Google Earth showing approximately the same view as Figure 18. Photograph June 2015. The bluffs are vegetated and not obvious in this photograph.

Figure 20. Forest Park Beach, City of Lake Forest. The shore-parallel breakwaters protect crescent-shaped beaches. Photograph 17 June 2014.

Figure 21. North Illinois sediment budget, southern section. All units in $\mathrm{yd}^{3} /$ year; $\Delta \mathrm{V}=$ net change in volume within the cell; $\mathrm{R}=$ amount of material removed from the cell, usually by dredging; $\mathrm{P}=$ amount of material placed in the cell. Background map from ESRI Maps and Data.

Figure 22. Shore protection at base of Harbor Street, Village of Glencoe, view looking south, November 1945 (photograph from the archives of the Beach Erosion Board, USACE).

Figure B-1. Elevation and volume change for box 1 of northern Illinois coastline. 68

Figure B-2. Elevation and volume change for box 2 of northern Illinois coastline. 69

Figure B-3. Elevation and volume change for box 3 of northern Illinois coastline. 70

Figure B-4. Elevation and volume change for box 4 of northern Illinois coastline. 71

\section{Tables}

Table 1. Major coastal features and infrastructure, Illinois North Shore 4

Table 2. Sediment gains and losses for budget calculation. ................................................................ 19

Table 3. Dredging, North Point Marina......................................................................................... 21

Table 4. Dredging, intake canal, Waukegan Electric Generating Station. .........................................2 22

Table 5. Dredging, Waukegan approach channel and advanced maintenance area. ...................... 24

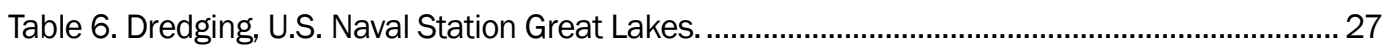

Table 7. Dredging, Forest Park boat ramp.................................................................................. 28

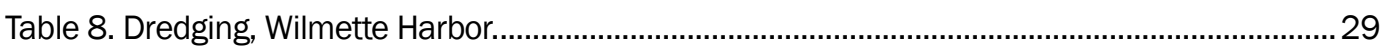

Table A-1. Sediment Budget, north Illinois................................................................................... 56 


\section{Preface}

This investigation was conducted by the U. S. Army Corps of Engineers (USACE), Regional Sediment Management (RSM) Program, which is funded by the Operation and Maintenance Navigation Business Line of Headquarters (HQ), USACE (Funding Account Code U4362913; AMSCO Code 008303). The RSM Program is administered by the U.S. Army Engineer Research and Development Center (ERDC), Coastal and Hydraulics Laboratory (CHL), Vicksburg, MS, under the Navigation Program of USACE. At the time this study was conducted, Mr. Jeffrey A. McKee was the HQUSACE Navigation Business Line Manager. The work was performed by the Navigation Division, Coastal Engineering Branch, of the ERDC CHL.

At the time of publication of this report, Dr. Katherine Brutsche, Coastal Engineering Branch, was USACE National RSM Program Manager. The ERDC Technical Director for Navigation was Mr. Charles E. Wiggins, CHL. Ms. Lauren Dunkin was Chief, Coastal Engineering Branch; and Dr. Jacqueline S. Pettway was Chief, Navigation Division, CHL.

COL Ivan P. Beckman was the Commander of ERDC, and Dr. David W. Pittman was the Director of ERDC. 


\section{Introduction}

\section{Background}

The North Shore of Illinois is a highly dynamic and diverse coastline with littoral processes complicated by coastal infrastructure, commercial harbors, and uncoordinated shoreline management. Historically, coastal management has not been conducted using a coordinated regional approach, which hindered the efficiency and effectiveness of management activities. The newly established Illinois Coastal Management Program (ICMP) is developing a comprehensive plan for shoreline management. The development of a regional sediment budget will support the ICMP and provide a valuable tool for federal, state, and local decision makers.

To date, the ICMP has not developed a comprehensive quantitative analysis of the littoral processes along the North Shore. A large amount of coastal data and analyses are available but is housed by a variety of agencies and municipalities. There are also gaps in the available data, such as mid-twentieth century bathymetry surveys.

\section{Objective}

This investigation will evaluate available coastal data and develop a comprehensive sediment budget for the region. A regional sediment budget is a valuable tool for supporting regional and federal planning efforts and for enabling more effective and cost-efficient sediment management informed by coherent and consistent information. Among the goals of developing a sediment budget are as follows:

- Gaining a better understanding of littoral transport in the area

- Identifying effects of harbor structures on littoral transport

- Identifying sources, sinks, and pathways of sediment.

By incorporating goals of Regional Sediment Management (Lillycrop et al. 2011), sediment will be treated as a resource to benefit the entire system rather than as a nuisance to be eliminated regardless of the consequences on the coastal environment. Managing sediment to benefit a region potentially saves money, allows use of natural processes to solve engineering problems, and improves recreation potential and habitat. 


\section{Approach}

This analysis of littoral transport covers the reach between the IllinoisWisconsin border and the City of Wilmette (Figure 1; Background map by Environmental Systems Research Institute [ESRI $\left.{ }^{\odot}\right]$ Maps and Data). This report summarizes the results of the sediment budget developed by the U.S. Army Engineer Research and Development Center, Coastal and Hydraulics Laboratory, (ERDC-CHL), and the U.S. Army Engineer District, Chicago (LRC), and describes the following:

- Data sources applicable to the study area

- Assumptions and limitations

- Recommendations for continued refinement.

Most units in this report are stated in English units, in correspondence with original data collection and with contemporary use for dredging volumes (cubic yards).

Figure 1. Study area, northern Illinois shore of Lake Michigan. Red outlines show sediment budget cells used in this analysis. (Cell Wl-1 from Kenosha, WI, to North Point Marina was not used in this analysis.) Background map from ESRI Maps and Data.

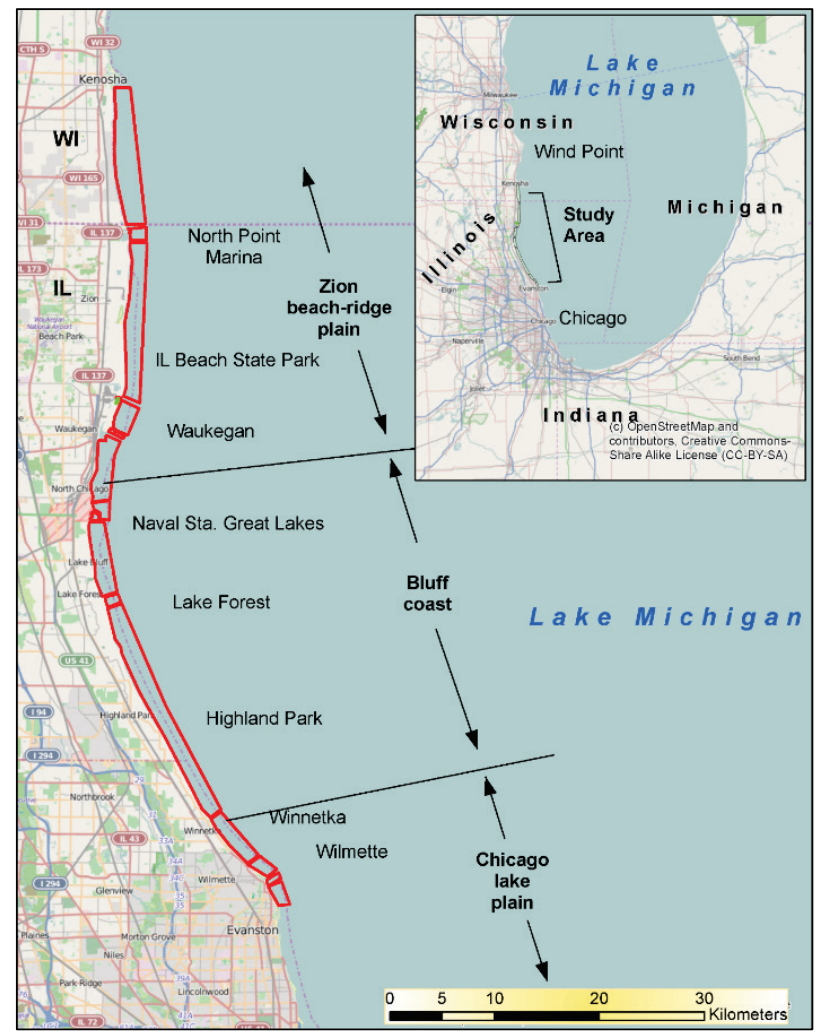




\section{Study Area and Physical Processes}

\section{Setting and management issues}

The North Shore is the northern half of the 63-mile Illinois shoreline on Lake Michigan (Figure 1). This is the most urbanized and populous section of coast along any of the Great Lakes. While the southern (Chicago) shore is almost entirely engineered and artificial, the North Shore, extending from the Illinois-Wisconsin state line to Wilmette, exhibits a diversity of geologic and engineered conditions. The presence of numerous large in-lake structures (e.g., harbors, jetties, detached breakwaters) has created significant littoral barriers. These barriers trap sediment, leaving major sections of coast sand-depleted and vulnerable to erosion via beach and bluff recession and lakebed downcutting. It is a major management challenge to maintain the effectiveness of coastal infrastructure while preserving the stability and integrity of the overall shore. This is further complicated by the shared responsibility for coastal management: the federal government, State of Illinois, local municipalities, and private landowners collectively manage portions of the shoreline.

The Illinois North Shore is diverse politically, geologically, and ecologically. Twelve communities face Lake Michigan as well as federal, state, and municipal infrastructure (Table 1). Ecological and recreational resources include the Adeline Jay Geo-Karis Illinois Beach State Park (IBSP), operated by the Illinois Department of Natural Resources (IDNR) and numerous municipal parks and beaches. Adding to the complexity is the presence of more than a hundred parcel-scale shore protection structures, many decades old and in various states of disrepair.

The North Shore is defined by three distinct coastal geomorphic divisions: the Zion beach-ridge plain, the glacial till bluff coast, and the Chicago lake plain (Figure 1). From north to south, the shoreline changes from a low sandy plain to a high bluff/ravine system (near Waukegan) to a low bluff/beach system (near Winnetka).

The northernmost $6 \mathrm{mi}$ of the study area are in the Zion beach-ridge plain and are part of the IBSP. Beach-ridge plains consist of linear, generally coast-parallel ridges of sand and gravel that are formed by wave action and that extend the coast outward into the adjacent ocean or lake as long as sufficient sediment supply is available (Chrzastowski and Frankie 2000). 
Table 1. Major coastal features and infrastructure, Illinois North Shore.

\begin{tabular}{|c|c|c|}
\hline Feature (North-South) & Ownership & Coastal Structure \\
\hline $\begin{array}{l}\text { Prairie Harbor Yacht Club, } \\
\text { Runaway Bay, WI }\end{array}$ & Private & Channel and rubblemound north jetty \\
\hline $\begin{array}{l}\text { North Point Marina, Winthrop } \\
\text { Harbor, IL }\end{array}$ & IDNR & Rubblemound breakwaters and shore armor \\
\hline Illinois Beach State Park & IDNR & Natural sand beach with limited sheet pile and groins \\
\hline $\begin{array}{l}\text { Zion Nuclear Power Station } \\
\text { (closed) }\end{array}$ & Exelon Nuclear & Rip rap behind natural sand beach \\
\hline $\begin{array}{l}\text { Waukegan Electric Generating } \\
\text { Station }\end{array}$ & Midwest Generation & Intake and outlet canals with sheetpile training wall \\
\hline Waukegan Harbor & City of Waukegan & $\begin{array}{l}\text { Parallel piers and a shore-connected timber crib north } \\
\text { breakwater }\end{array}$ \\
\hline U.S. Naval Station Great Lakes & U.S. Navy & Rubblemound jetties enclosing harbor \\
\hline Prospect Ave., Lake Forest & City of Lake Forest & Misc. shore-parallel rubblemound breakwaters \\
\hline Spruce Ave., Forest Park & City of Lake Forest & Misc. shore-parallel rubblemound breakwaters \\
\hline $\begin{array}{l}\text { Forest Park, Lake Forest } \\
\text { Harbor }\end{array}$ & City of Lake Forest & Shore-parallel rubblemound breakwaters, small harbor \\
\hline Fort Sheridan & Private & Misc. groins \\
\hline $\begin{array}{l}\text { Park Ave. boat ramp, Highland } \\
\text { Park }\end{array}$ & $\begin{array}{l}\text { Park Dist. Highland } \\
\text { Park }\end{array}$ & Sheetpile rectangle protruding into lake \\
\hline Glencoe Beach, Glencoe & Park Dist. Glencoe & Sheetpile terminal groin holding beach \\
\hline $\begin{array}{l}\text { Winnetka Power Generating } \\
\text { Sta. outfall }\end{array}$ & Village of Winnetka & Concrete piers and canal \\
\hline Lloyd Park, Winnetka & Village of Winnetka & Sheetpile "L"-shaped pier \\
\hline Wilmette Park/Gillson Park & Park Dist. Wilmette & Sand beach held by rubble terminal groin \\
\hline $\begin{array}{l}\text { Wilmette Harbor (mouth of } \\
\text { North Shore Channel) }\end{array}$ & Village of Wilmette & Rubblemound and sheetpile piers, south pier deteriorated \\
\hline
\end{tabular}

This is the only remaining area along the north shore that has not been heavily altered by urbanization and coastal engineering. The park supports 14 natural communities and provides habitat for more than 500 plant and 300 animal species, including several threatened and endangered species. However, because of a lack of new sediment in the system, beach erosion has caused serious shoreline retreat over the decades.

The bluff coast consists of glacial bluffs with elevations above lake level upwards of 80 feet (ft). Many of the bluffs have been armored with revetments, bulkheads, and seawalls of varying condition. Because of the armoring, it is believed that minimal sediment is now supplied to the 
littoral environment. Silts and clay come down some of the creeks and washes but do not deliver any significant amount of sand-sized sediment.

The Chicago lake plain in the south is emergent former lake bottom, with minor gradient change in the offshore topography (Bretz 1955). Much of the shoreline in this section has been armored and artificially modified, especially from Evanston, IL, to Gary, IN, and will not be considered in this report. There is essentially no longshore transport in this zone.

Given the diversity of this 32 -mile reach, shoreline management is a significant challenge for both governmental and non-governmental entities. Considerable sediment management is occurring at a site-specific basis by government and private entities. In January 2012, the State of Illinois entered the National Oceanic Atmospheric Administration (NOAA) Coastal Zone Management program and is currently in the process of coordinating with the various stakeholders to develop a plan for the coastline that establishes regional coastal management and implementation priorities.

Planning for the best uses of sediment within the system is important because much of the coast exhibits sediment-starved conditions. In this region, the net direction of the littoral drift is from north to south. Based on historical profile data, in the early part of the twentieth century, the littoral transport rate was 90,000 cubic yards per year (yd3/year) in the Zion beach-ridge area and 57,000 yd3/year along the bluff coast (USACE 1953). It is unknown why the rate of 90,000 for the Zion beach-ridge region is less than the current computed value for the region north of Waukegan Harbor (to be discussed below). This discrepancy requires further investigation beyond the scope of this study; however, it is potentially a function of the data sources or measurement methods used in the 1953 study, impacts from updrift littoral barriers, or the result of natural geologic processes (i.e., southward migration of the Zion Beach Ridge Plain). Over the past century, the construction of numerous in-lake structures (e.g., harbors and jetties) has created littoral barriers that trap large volumes of littoral sediment, leaving downdrift (south) areas exposed and vulnerable to erosion. Illinois Beach State Park, the most significant ecological resources along this reach has experienced long-term erosion rates as high as $10 \mathrm{ft} /$ year. 


\section{Sediments and littoral transport}

A fundamental question pertaining to sand management along the Illinois shore is "Where does beach sand come from?" Sand on southern Lake Michigan beaches in Indiana historically was supplied from bluff and lake bed erosion and to a lesser degree, intermittent stream input (Shabica and Pranschke 1994). Along the Michigan shoreline, bluff erosion is the primary contributor of sand with elevations up to $80 \mathrm{ft}$.

However, along the Illinois shore, the bluffs, often up to 70 or $80 \mathrm{ft}$ high, contain only minor amounts of sand and gravel. The bluffs consist of high, lake-terrace deposits underlain by Pleistocene Wadsworth Till of the Highland Park Moraine and contain approximately $85 \%$ clay and $15 \%$ clastic materials (i.e., sand, gravel, cobbles, and boulders [Shabica et al. 2010]). Lineback (1974) reported 10\% sand. Recent borings reveal that in some areas, the percentage of coarse material is less. Figure 2 and Figure 3 show the locations of borings at Fort Sheridan and Rosewood Beach. The material within the cores was averaged to produce a single pie chart. The cores collected on the bluffs contain $100 \%$ till with only trace amounts $(<5 \%)$ of gravel and sand. The samples on the beach contain a sand wedge with clay till underneath. Data were compiled from unpublished contractor reports provided to LRC (Soil and Material Consultants, Inc., Chicago Testing Laboratory, Inc., and AECOM).

Streams along the Illinois shore supply mostly fine-grain material by means of ravines cut into the bluffs. A lag of cobble and gravel line many of these streams, now often augmented by limestone and other material placed to reduce ravine downcutting (Shabica et al. 2010). At U.S. Naval Station Great Lakes, Pettibone Creek has delivered so much clay and silt to the old boat basin and the inner harbor that they became almost unusable and required dredging in 2009-2011 (North Wind 2011a,b,c).

Therefore, if the local geology did not supply sand to the littoral system, the source must be farther north. The IBSP is a major beach ridge complex, with its southern terminus just north of Waukegan. The major sand and gravel deposit on which Illinois Beach State Park resides is likely a large glacial-fluvial deposit that originally was a sub-glacial delta. The source area may have been Wind Point, Wisconsin (Figure 1). This subglacial deposit resided to the south of Wind Point until the lake reached the Nippising level approximately 5,500 years before present. Wave action then transported the sand southward. The Zion Beach Ridge Plain 
(Kenosha to Waukegan) is the present manifestation of this sand accumulation. In the geologic past, this sand body was farther north and was wider (east-to-west) and shorter (north-to-south), but has been translating southward through time by littoral transport.

Figure 2. Borings at Fort Sheridan, IL, showing the preponderance of clay in the till bluffs. Numbers represent the boring identification and total boring depth. Photo by ESRI Maps and Data.

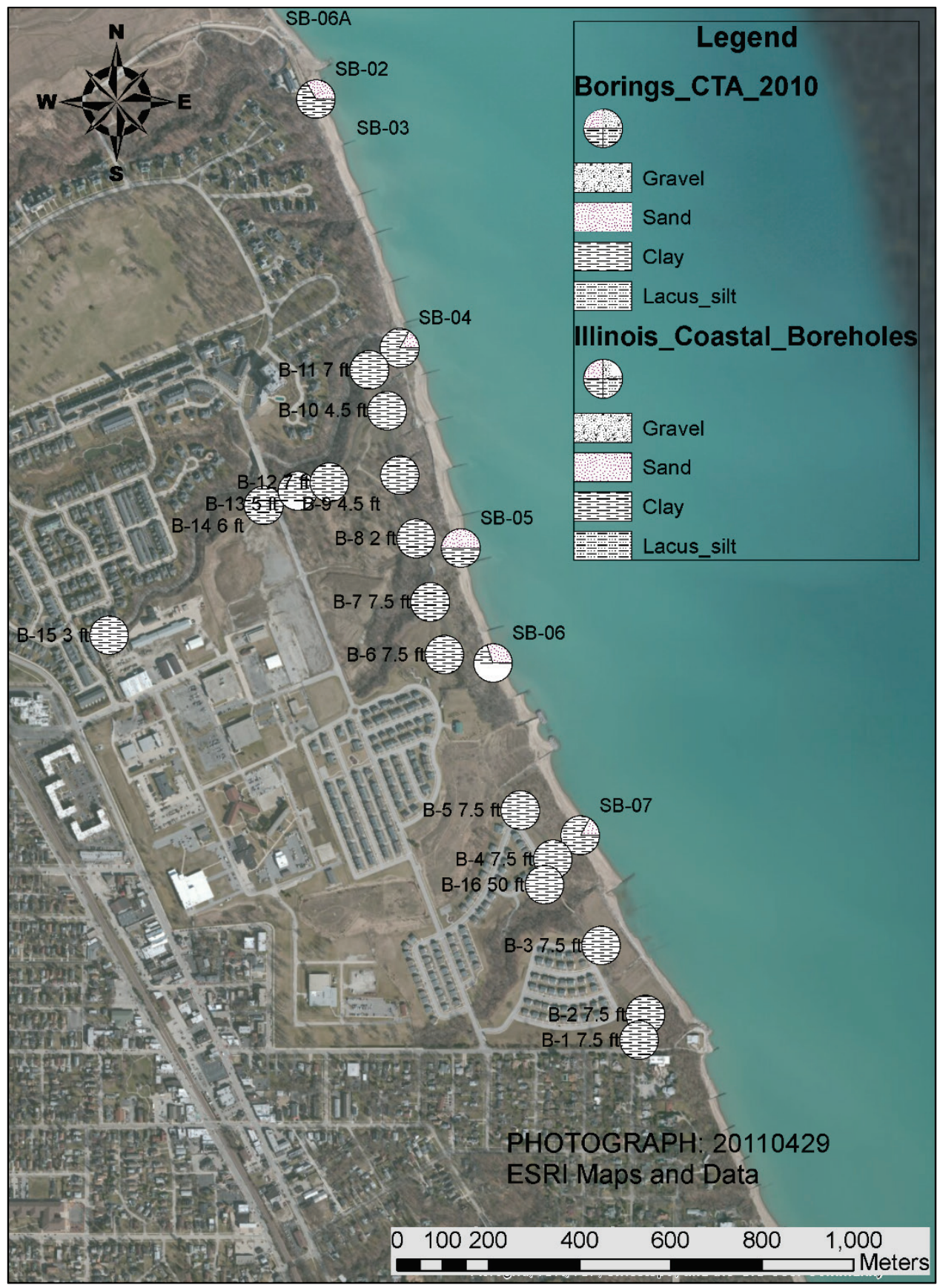


Figure 3. Borings at Rosewood Beach in Highland Park, IL. Clay is the predominant material at most sites, although boring B-2 (50 ft long) contained close to $25 \%$ sand. The average percent of sand for the core borings was approximately $5 \%$. Photo by ESRI Maps and Data.

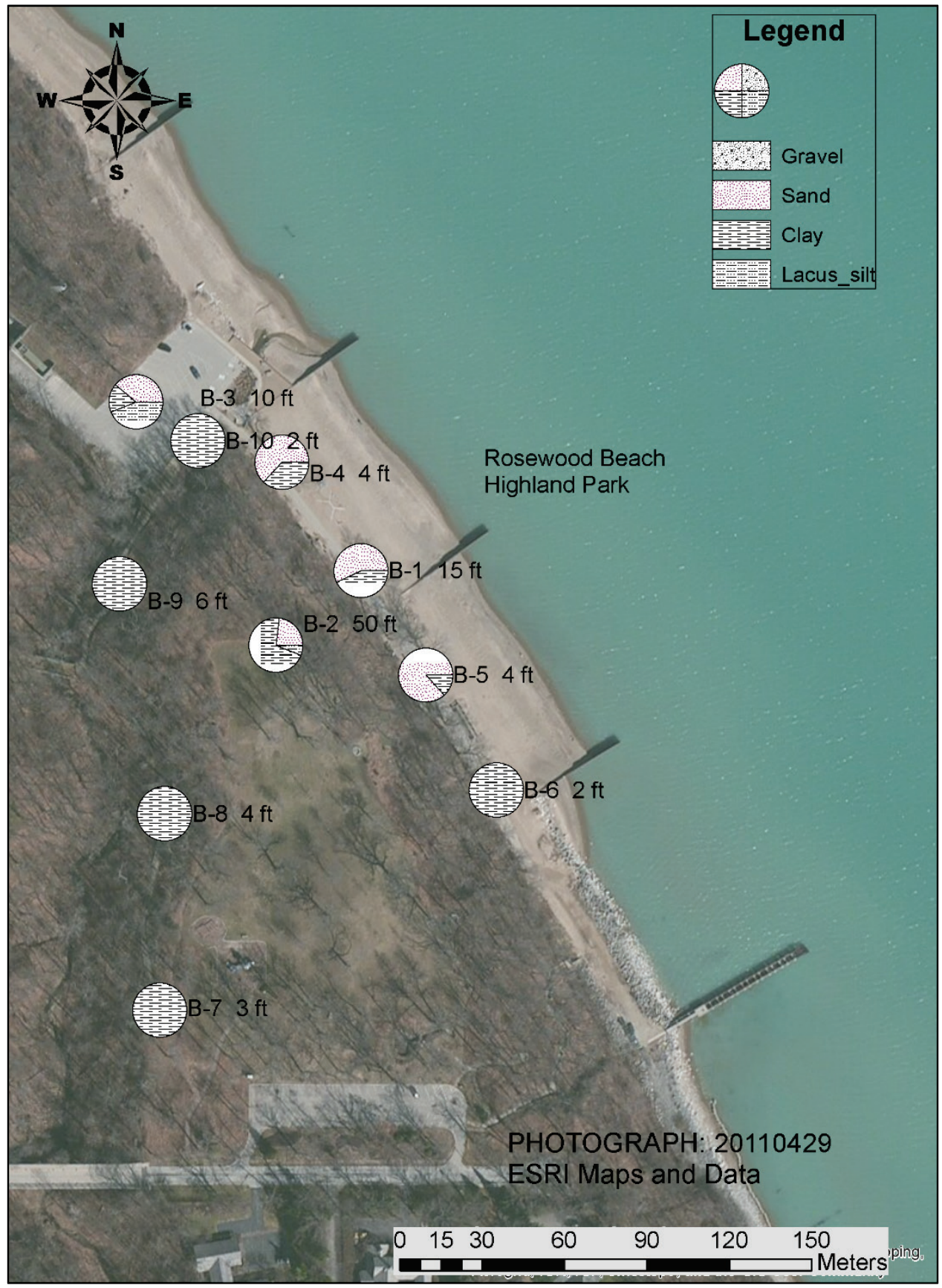

The sand plain is not a closed sediment system. Erosion on the north and deposition on the south contributed to the southward translation, and some sand clearly moves southward beyond the southern limit of the plain. This is demonstrated by the persistent need to dredge Waukegan Harbor entrance (discussed in the sediment removal and placement section of the report below). In the pre-engineered state, the Illinois coast 
was the southern end of a littoral transport pathway that began along the Wisconsin coast at least as far north as Sheboygan (86 miles north of the Wisconsin-Illinois border) and likely as far north as Manitowoc (110 miles north of the border). The evidence for this is the southward deflection of stream mouths recorded in the early mapping of streams along western Lake Michigan. Even along the Wisconsin coast, sand is limited in the bluff stratigraphy. Thus, coarse-grain material from glacial fluvial deposits was likely the source of sand along the Illinois shore.

Since the late-180os to mid-1900s, most bluffs along the Illinois lakeshore have been protected with steel, concrete, timber, rubble, and stone armor. Limited unprotected sections of till bluffs are found in Highland Park and Lake Forest, but otherwise, the coast south of Waukegan is about 95\% engineered and stable (Shabica et al. 2004). Compounding the problem, structures like the jetties and breakwaters at Waukegan, Great Lakes, and Wilmette almost totally interrupted the movement of sediment to the south. Therefore, a comprehensive sand management plan for the North Shore will require managing and recycling the sand that is presently in the system, while anticipating minimal new supply coming in from the north. 


\section{Previous Studies}

The Illinois North Shore of Lake Michigan has been extensively studied over the past century. The effects of coastal erosion and accretion in this area were first recognized in the late 1800 s as part of the construction of the Waukegan Harbor breakwater jetties. Two comprehensive studies of shore erosion along the entire Illinois coast were completed first by USACE in 1953 (USACE 1953) and then by the State of Illinois Division of Waterways in 1958 (State of Illinois 1958). These two studies utilized shore position and nearshore bathymetry data from 1872 to 1873,1909 to 1911,1937 to 1938 , 1946 to 1947 , and 1955 to map coastal change along the Illinois lakeshore. These two studies provided a benchmark for further study by the State of Illinois in the late 1970s and again by USACE in 1989 (USACE 1989). The Illinois State Geological Survey (ISGS) conducted a series of coastal studies along the Illinois North Shore in the 1990 s and early 2000 in conjunction with the construction of North Point Marina near the border with Wisconsin (Chrzastowski et al. 1993, 1996; Chrzastowski 2003). These studies provide the most recent documentation of coastal erosion and accretion trends and associated littoral transport rates. 


\section{Data Sources, Management, and Organization}

\section{Software}

Spatial data were organized and displayed in ESRI ArcMap ${ }^{\mathrm{TM}}$ Geographic Information System (GIS) software, version 10.1. Data were projected in State Plane Illinois East Zone, U.S. feet, North American Datum 1983 (NAD83). Features specifically related to an elevation are referenced to International Great Lakes Datum (IGLD) of 1985 (Coordinating Committee on Great Lakes Basic Hydraulic and Hydrologic Data 1992).

Dredge volumes have been reported in cubic yards, as per common usage for dredging and engineering projects in this area.

Sediment volumes have been entered into the USACE Sediment Budget Analysis System software, which plots the cells and fluxes within the ArcMap environment (Dopsovic, Hardegree, and Rosati 2002; Rosati and Kraus 2001)

\section{Contemporary aerial photography}

Contemporary aerial photography of southern Lake Michigan and the surrounding states is available online from ESRI Maps and Data via the ArcGIS Map service. The World Imagery photography is dynamically scaled as needed. For the project area, maximum resolution was 0.3 meter (m) ( $\approx 13$ inches). For most of the study area, the latest photography was 29 April 2011. It was primarily used for visual reference of topographic and man-made (anthropogenic) features. On the fillet north of Waukegan Harbor, the contemporary (photograph) shoreline was compared to historic shorelines to compute sediment accumulation.

\section{Lidar data}

Light detection and ranging (lidar) data were collected along the coast of Illinois during the summers of 2008 and 2012 under the USACE National Coastal Mapping Program (NCMP) by the Joint Airborne Lidar Bathymetry Technical Center of Expertise using the Compact Hydrographic Airborne Rapid Total Survey system (Macon 2009; Wozencraft and Millar 2005; Wozencraft and Lillycrop 2006). Coverage typically extended from the 
waterline $1,600 \mathrm{ft}(500 \mathrm{~m})$ inland and offshore $3,300 \mathrm{ft}(1,000 \mathrm{~m})$ or to laser extinction. The NOAA Coastal Services Center supplies the USACE lidar data in various formats as requested by the user.

To measure the amount of bluff recession, historical bluff edge data collected by the ISGS were compared with the 2012 lidar data. The lidar was processed by NOAA with a contour interval of $1 \mathrm{~m}$, with horizontal and vertical datum of NAD83 Illinois State Plane east zone, Federal Information Processing Standard (FIPS) 1201 and North American Vertical Datum of 1988 (NAVD88), respectively. Figure 4 plots the 2012 lidar data in Highland Park along with the older ISGS data shown as colored points. In this example, the 1987 bluff locations are slightly behind (landward) of the contemporary bluff edge, which is likely an artifact of the data given that it is not possible for the bluff to have advanced unless landowners constructed retaining walls and added fill. The discrepancy may be a result of an interpretation error or original source material. The 1987 bluff edge position was interpreted from aerial photography using optical methods. If the photographs had been flown during partial or full foliage, it may have been difficult to determine the exact edge. The older bluff dates were from charts, which may have survey or printing errors. The conclusion for this area is that the bluffs have not retreated since 1987 because of armoring and bluff protection measures undertaken by property owners.

To measure changes in offshore bathymetry, the 2012 lidar data were used in the form of GeoTiff files with elevations in feet, NAVD88, and horizontal datum of NAD83 Illinois State Plane east zone, (Federal Information Processing Standard, Publication 1201 [FIPS 1201]). This was gridded data with cell size of $10 \times 10 \mathrm{ft}$ (Figure 5). The 2012 lidar dataset had data gaps in some areas along the coast. The 2008 dataset was used to fill some of the gaps that were occurring in turbid areas possibly as a result of runoff or storms suspending sediment during the airborne survey timeframe. The percentage of data gaps within each sediment budget cell is less than 10\%, so the 2012 lidar dataset was used as the principle dataset with 2008 coverage filling in the missing bathymetry data. One exception was in Cell 12, which used the 2008 dataset to cover over $75 \%$, so for this cell, the sediment budget calculations used 2008 for the end year. 
Figure 4. Elevation contours derived from lidar data collected in 2012 compared with historical bluff edge points from ISGS, Highland Park, IL. Closely spaced contours indicate steep bluffs or ravines. Photo by ESRI Maps and Data.

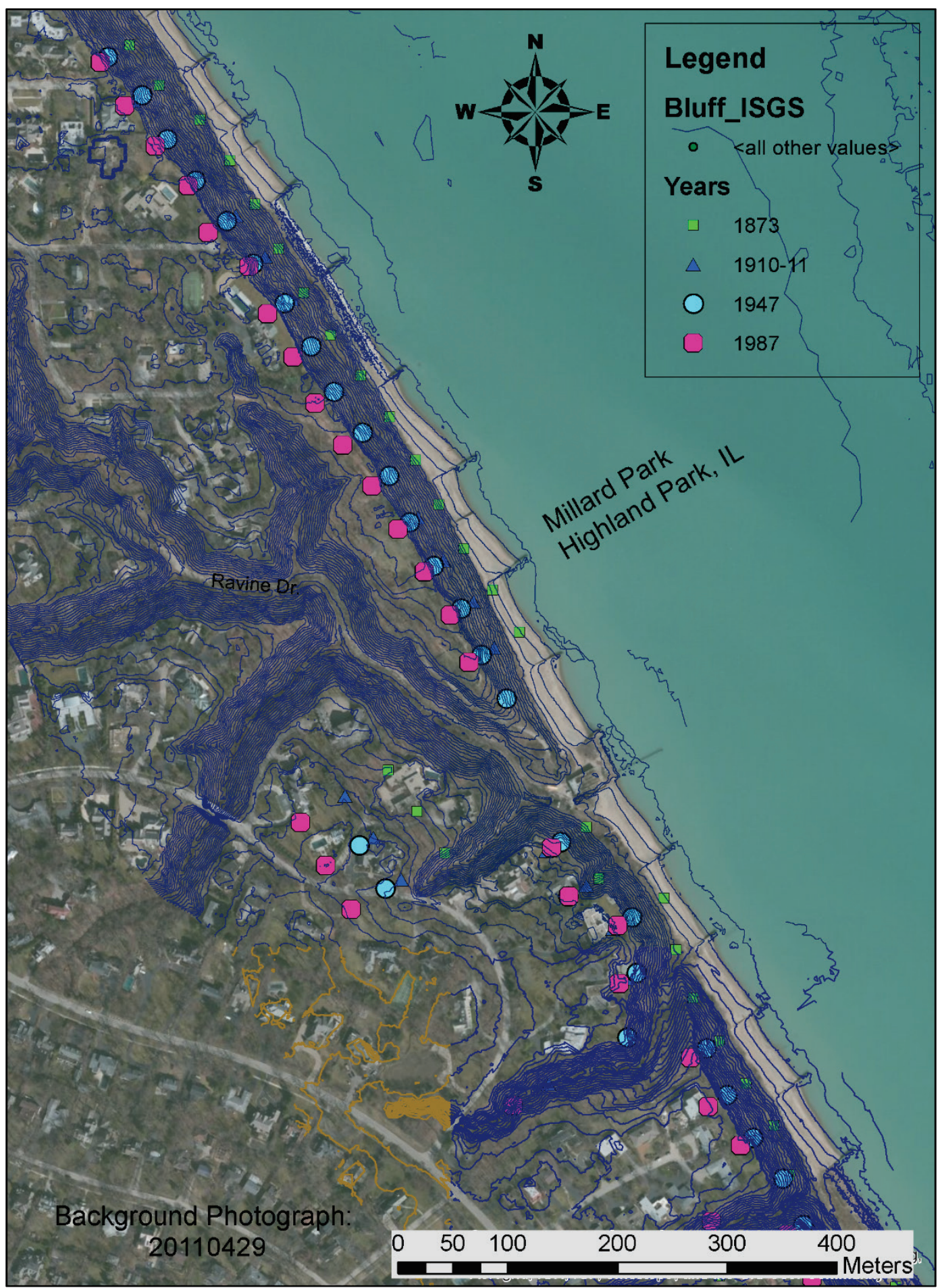


Figure 5. Nearshore bathymetry from 2012 lidar data, gridded at $10 \mathrm{ft} \times 10 \mathrm{ft}$ cell size Background map from ESRI Maps and Data.

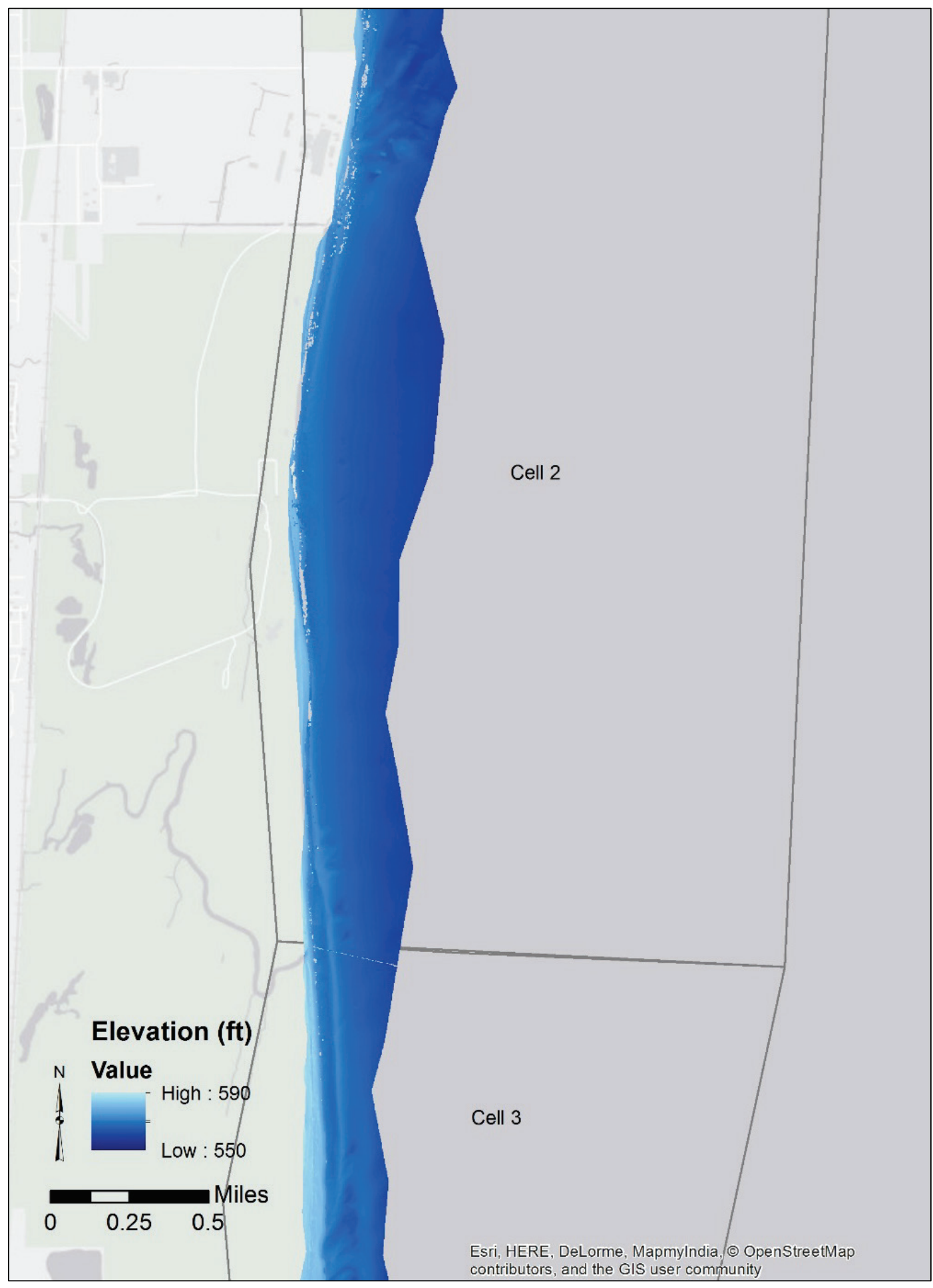




\section{Nearshore bathymetry mid-1970s}

The ISGS prepared an Illinois coastal atlas based on nearshore bathymetry surveys conducted by the agency in the 1970s (ISGS 1988). The atlas is unpublished, but the 1988 version was supplied to ERDC-CHL for this study. This was the only mid-century bathymetry available for the shallow offshore waters along the Illinois coast. Digital data from NOAA were too far offshore and too sparse to be useful for this study. Eighteen of the ISGS sheets were geo-referenced to fit to the correct locations along the shore. Figure 6 is an example of charts 10 and 11 from Waukegan. The isobaths (bottom contours) were based on surveys run during 1974-1976, adjusted to a hypothetical lake level of $581.0 \mathrm{ft} \mathrm{IGLD} 1955$ (NOAA 1980). The zero contour shown on the maps represents the April 1988 shoreline. The contours were digitized and stored as shapefiles. The contours were adjusted from IGLD 1955 to NAVD88 and used to construct a Triangular Irregular Network (TIN) surface with ESRI ArcMap software. The TIN surface was then converted into a grid with $10 \mathrm{ft} \times 10 \mathrm{ft}$ cells to permit direct comparison with the 2012 lidar grids.

Figure 7 shows the comparison of the mid-1970s bathymetry with the 2012 lidar data. The data show that most of the lakebed off the IBSP lost sediment over the years, but sand accumulated in the fillet north of the jetties at Waukegan Harbor. Some of the lakebed loss might consist of till, but the portion of the shore off IBSP is more sand rich than the lakebed south of Waukegan because of the presence of the ancient beach ridge plain. South of Waukegan, the lakebed consisted of glacial till with a sand content of approximately $5 \%$ (per analysis of bluff core data, shown in Figure 3). Therefore, only $5 \%$ of the sediment volume change of the lakebed and bluffs was included in the sediment budget. The remaining 95\% consists of fine-grained silt and clay, which is lost in the surf zone and does not contribute to the littoral transport. This process underscores a fundamental difference between a bluff coast and a sandy shore. The sandy beach can erode and recover depending on sand supply, whereas weathering and erosion of a bluff shore is a one-way process. Once the till bluff is cut back, no contemporary hydrodynamic process can rebuild the clay/silt/sand matrix. 
Figure 6. Map frames 10 and 11 from ISGS 1988 Illinois coastal atlas. Isobaths were based on surveys completed during 1974-1976, adjusted to a hypothetical lake level of $581.0 \mathrm{ft}$ IGLD 1955. Background map from ESRI Maps and Data.

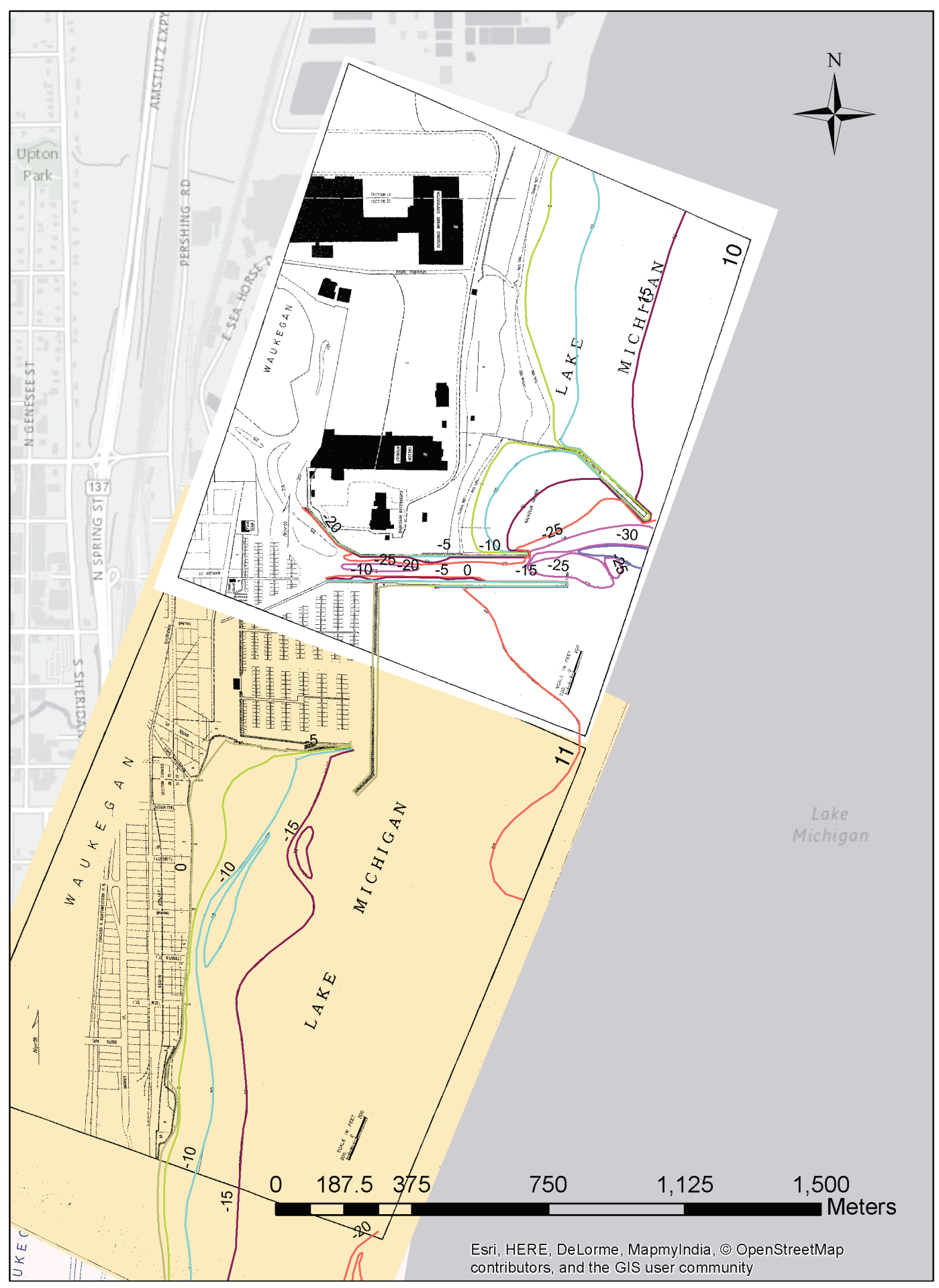


Figure 7. Lakebed comparison between mid-1970s acoustic and 2012 lidar bathymetry. Contours were traced from the ISGS coastal atlas (1988 publication date but containing 1974-1976 data). Background map from ESRI Maps and Data.

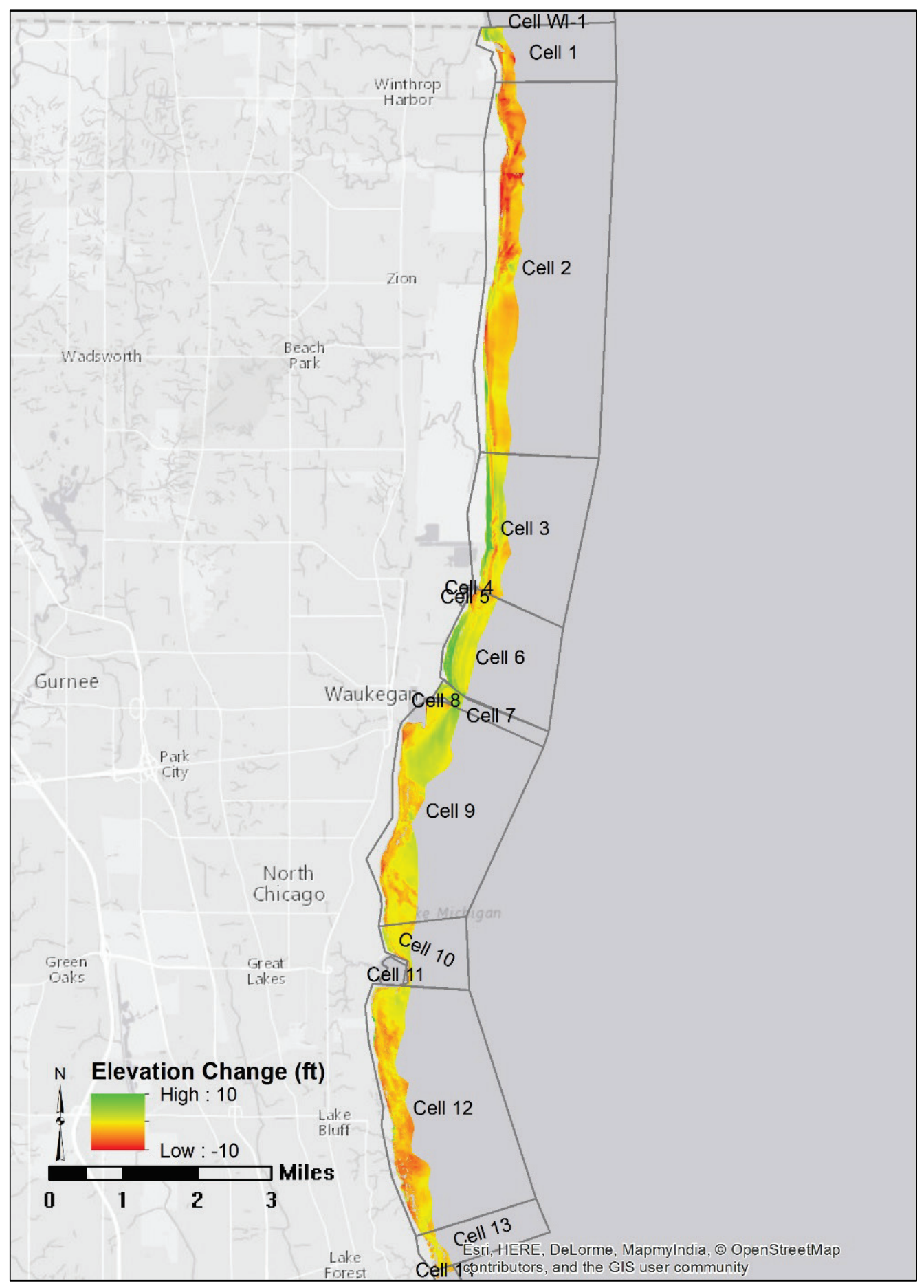




\section{Sediment Budget Cells}

A sediment budget is a tallying of sediment gains and losses, or sources and sinks, within a specified control volume (or cell), or series of connecting cells, over a given time. Cells are defined by geologic features or natural geomorphic boundaries, data resolution, coastal structures, and knowledge of the site. Sediment may pass from one cell to another, either naturally by wave and current-induced transport or artificially via dredging and placement. Note that sediment movement from one cell to the next cell downdrift is not $100 \%$ efficient because some sediment can be transported offshore or onshore. Along this coast, areas with seawalls or shore protection have minimal onshore sediment transport except in the rare cases where storm waves break high enough to deposit water and sand over the top of the walls. Rosati (2005) provides a more complete description of sediment budget methodology.

The basic sediment budget equation can be expressed as follows:

$$
\sum Q_{\text {source }}-\sum Q_{\text {sink }}-\Delta V+P-R=\text { Residual }
$$

where:

$\mathrm{Q}_{\text {source }}$ and $\mathrm{Q}_{\text {sink }}=$ the sources and sinks to the control volume, respectively

$\Delta V=$ the net change in volume within the cell

$P=$ the amounts of material placed in the cell

$R=$ the amounts of material removed from the cell (usually dredging)

Residual $=$ the degree to which the cell is balanced.

The term Residual needs explanation:

- It is the remainder from the accounting of defined sources and sinks including $\Delta V$, and for a balanced cell, the residual is zero.

- A cell may have Residual $=0$ if all sources and sinks are accounted, but the cell may still have net sediment gain or net loss because of a flux in or out.

- Residual $=0$ does not mean that all the fluxes in each littoral cell are understood or all sources and sinks of the system $\left(Q_{\text {source }}\right.$ and $\left.Q_{\text {sink }}\right)$ and artificial intervention ( $P$ and $R$ ) have been resolved perfectly. However, all terms were adjusted to ensure Residual $=0$ in the calculation. 
For a region consisting of many contiguous cells, such as the North Illinois study area, the budgets for individual cells must algebraically balance to achieve a balanced budget for the entire regional system.

Table 2 summarizes sediment gains and losses that may apply to a Lake Michigan budget cell. Not all of these are applicable today. For example, sand mining is no longer conducted, although gravel was mined from the Illinois Beach State Park on an industrial basis in the early twentieth century. Offshore flux to deep water and aeolian transport are not accounted for in this budget because no accurate estimates for these processes currently exist. For most of the study area, aeolian transport is assumed to be zero because in a developed terrain consisting of suburbia, there is no source of sand. An exception is a loss of sand from the dredge pile at the Waukegan power plant (discussed below). Flux to deep water can be included in a future refinement of the budget. Figure 1 shows the budget cells considered for this study. These are similar to the cells used by Chrzastowski and Trask (1996a) for the USACE Illinois Shoreline Erosion Interim IV study, but some of the 1996 cells have been subdivided into smaller units (for example, the intake canal at Waukegan Electric Generating Station and the sand pile on land are treated as two cells).

Table 2. Sediment gains and losses for budget calculation.

\begin{tabular}{|l|l|}
\hline Gains & Losses \\
\hline Longshore transport into cell & Longshore transport out of cell \\
\hline Riverine supply (minimal in N. Illinois) & Offshore transport (to deep water) \\
\hline Bluff erosion & Wind transport inland or out to lake \\
\hline Wind transport onto the beach & Transport into dredged navigation channels \\
\hline Onshore transport & $\begin{array}{l}\text { Beach mining or other anthropogenic causes } \\
\text { (no longer applicable) }\end{array}$ \\
\hline Beach nourishment & \\
\hline Dumping of debris (no longer applicable) & \\
\hline
\end{tabular}

Accretion $(\Delta V)$ is entered as a positive value while erosion is a negative. Longshore sediment transport from updrift is shown as a flux into the cell while sediment moving downdrift is a flux out of the cell. The fluxes are inferred mathematically based on dredging or volumetric changes; they have not been measured with sediment traps or other in situ methods. The budget is presented as an annual flux rate, resulting in a time-averaged net 
transport (not gross). The flux rate during any given year may be different for climatological reasons:

- Flux rate may be seasonal or even reverse direction.

- Storms are likely to alter the flux rates, and a given year with more or fewer storms will result in different magnitudes of transport.

- Alongshore vs. across-shore transport will also be dependent on storminess. Increased storminess could result in enhanced overwash (in the Illinois Beach State Park area) or offshore loss of sediment.

Construction of shore protection between the analysis dates, 1974 and 2012, may have altered the flux, but it is not possible to examine the effect. However, much of this shore south of Waukegan has been heavily armored for decades, and this budget is largely an examination of sediment flux along a developed shore.

Artificial sediment movement out of the cell, such as the dredging from the intake canal at the Waukegan Electric Generating Station, is not shown as a flux but rather is entered as a positive number for the term $R$ (for removal). Artificial placement, such as beach nourishment at IBSP, is entered as a positive number for term $P$ (placement).

Each cell represents a geomorphic unit that includes the beach and the shallow nearshore zone. The dimension alongshore represents the linear extent of the cell, but the shore-perpendicular width does not represent a specific or fixed value. The depth of the nearshore zone is unspecified but is intended to include the active sediment zone (approximately $20-25 \mathrm{ft}$ water depth). Cells have been drawn with exaggerated cross-shore dimension for display purposes on the figures.

Flux arrows shown in figures in this report indicate the direction of net sediment movement, but the lengths of the arrows have not been scaled to indicate magnitude. Magnitudes and other values are listed in Table A-1 in Appendix A. 


\section{Sediment Removal (Dredging) and Placement}

Table 3 lists dredging from the North Point Marina ${ }^{1}$

Table 3. Dredging, North Point Marina.

\begin{tabular}{|l|c|l|}
\hline Date & $\begin{array}{c}\text { Volume } \\
\left(\mathbf{y d}^{3}\right)\end{array}$ & \\
\hline $6 / 1 / 1995$ & & $\begin{array}{l}\text { Initial marina date used for } \\
\text { calculations }\end{array}$ \\
\hline $1995-1996$ & 24,000 & Foyle and Chrzastowski (1997, p. 19) \\
\hline $6 / 1 / 1997$ & 15,000 & $\begin{array}{l}\text { From David L. Suthard, General } \\
\text { Manager, North Point Marina, }\end{array}$ \\
\hline $6 / 1 / 1999$ & 15,000 & \\
\hline $3 / 21 / 2003$ & 8,423 & \\
\hline $5 / 31 / 2007$ & 7,553 & \\
\hline $7 / 31 / 2007$ & 16,552 & \\
\hline $11 / 20 / 2008$ & 20,150 & \\
\hline $9 / 29 / 2009$ & 15,006 & \\
\hline $4 / 30 / 2010$ & 4,229 & \\
\hline $8 / 31 / 2011$ & 8,859 & \\
\hline $5 / 31 / 2012$ & 5,529 & \\
\hline $5 / 31 / 2013$ & 31,645 & \\
\hline Total & 171,946 & \\
\hline Years & 17.999 & \\
\hline Annual & 9,553 & Avg. 1995-2013 \\
\hline
\end{tabular}

1 David L. Suthard, General Manager, North Point Marina, personal communication, 21 August 2014. 
Table 4 lists sand dredged from the intake canal at the Waukegan Electric Generating Station.

Table 4. Dredging, intake canal, Waukegan Electric Generating Station.

\begin{tabular}{|c|c|}
\hline Date & Volume $\left(y d^{3}\right)$ \\
\hline 1958 & 120,000 \\
\hline 1961 & 125,000 \\
\hline 1963 & 50,000 \\
\hline 1965 & 100,000 \\
\hline $1968-69$ & 120,000 \\
\hline 1972 & 100,000 \\
\hline 1973 & 103,000 \\
\hline 1976 & 78,700 \\
\hline 1977 & 149,000 \\
\hline 1981 & 20,000 \\
\hline 1983 & 42,000 \\
\hline 1984 & 90,000 \\
\hline 1986 & 102,700 \\
\hline 1987 & 80,000 \\
\hline 1988 & 7,000 \\
\hline 1990 & 35,600 \\
\hline 1992 & 114,700 \\
\hline 1995 & 20,000 \\
\hline 1997 & 20,000 \\
\hline 1999 & 11,000 \\
\hline 2000 & 50,000 \\
\hline 2003 & 38,573 \\
\hline $2003 / 2004$ & 63,492 \\
\hline $2004 / 2005$ & 93,850 \\
\hline $2005(12 / 16-12 / 31)$ & 28,595 \\
\hline $2006(1 / 3-1 / 19)$ & 84,510 \\
\hline $2007(1 / 1$ - 1/24) & 160,900 \\
\hline $2008(1 / 08-2 / 08)$ & 80,990 \\
\hline $2009(2 / 24-2 / 26)$ & 39,420 \\
\hline
\end{tabular}




\begin{tabular}{|c|c|}
\hline Date & Volume $\left(\mathrm{yd}^{3}\right)$ \\
\hline $2010(1 / 4-1 / 6)$ & 66,225 \\
\hline $2011(1 / 3-1 / 31)$ & 91,400 \\
\hline $2012(1 / 1-1 / 31)$ & 74,280 \\
\hline $2013(1 / 1-1 / 31)$ & 66,410 \\
\hline $2014(1 / 02-3 / 31)$ & 50,790 \\
\hline Total & $2,478,135$ \\
\hline $\begin{array}{c}\text { Years (2-year interval in } \\
\text { 1950s) }\end{array}$ & 58 \\
\hline Average annual & 42,726 \\
\hline $\begin{array}{c}\text { Total Volume 1995- } \\
\text { 2014 }\end{array}$ & $1,040,435$ \\
\hline $\begin{array}{c}\text { Years (assume 1-year } \\
\text { interval) }\end{array}$ & 20 \\
\hline Average 1995-2014 & 52,022 \\
\hline
\end{tabular}

Source: Frederick Veenbaas, NRG Energy Services, LLC, 2/4/2015 
Table 5 lists dredging from the approach channel and advance maintenance area of Waukegan Harbor. This is a federal navigation channel, and work was performed by contract plant for LRC or by federal plant (data from internal LRC documents). Dredge requirements have increased significantly since the late-2000s as the fillet beach to the north has reached capacity and sand wraps around the north jetty and enters the channel. The 1995-2013 value is used in this sediment budget.

Table 5. Dredging, Waukegan approach channel and advanced maintenance area.

\begin{tabular}{|c|c|c|}
\hline Year & Volume $\left(y d^{3}\right)$ & Placement \\
\hline 1889 & 17,805 & Offshore \\
\hline 1890 & 63,069 & Offshore \\
\hline 1892 & 9,714 & Offshore \\
\hline 1893 & 50,292 & Offshore \\
\hline 1897 & 128,862 & Offshore \\
\hline 1898 & 58,249 & Offshore \\
\hline 1900 & 33,650 & Offshore \\
\hline 1903 & 26,722 & Offshore \\
\hline 1905 & 280,900 & Offshore \\
\hline 1906 & 5,004 & Offshore \\
\hline 1907 & 9,129 & Offshore \\
\hline 1908 & 6,426 & Offshore \\
\hline 1909 & 14,866 & Offshore \\
\hline 1910 & 53,453 & Offshore \\
\hline 1912 & 7,791 & Offshore \\
\hline 1913 & 10,220 & Offshore \\
\hline 1914 & 31,929 & Offshore \\
\hline 1915 & 31,163 & Offshore \\
\hline 1916 & 37,106 & Offshore \\
\hline 1917 & 19,600 & Offshore \\
\hline 1918 & 28,880 & Offshore \\
\hline 1919 & 50,510 & Offshore \\
\hline 1920 & 16,837 & Offshore \\
\hline 1921 & 36,750 & Offshore \\
\hline 1922 & 59,500 & Offshore \\
\hline
\end{tabular}




\begin{tabular}{|c|c|c|}
\hline Year & Volume $\left(y d^{3}\right)$ & Placement \\
\hline 1923 & 30,000 & Offshore \\
\hline 1924 & 50,000 & Offshore \\
\hline 1925 & 41,700 & Offshore \\
\hline 1926 & 60,498 & Offshore \\
\hline 1927 & 73,622 & Offshore \\
\hline 1928 & 77,359 & Offshore \\
\hline 1930 & 111,485 & Offshore \\
\hline 1931 & 90,164 & Offshore \\
\hline 1933 & 28,500 & Offshore \\
\hline 1934 & 29,000 & Offshore \\
\hline 1936 & 18,746 & Offshore \\
\hline 1937 & 89,871 & Offshore \\
\hline 1939 & 23,917 & Offshore \\
\hline 1947 & 56,041 & Offshore \\
\hline 1950 & 29,640 & Offshore \\
\hline 1958 & 108,200 & Offshore \\
\hline 1960 & 12,629 & Offshore \\
\hline 1961 & 39,900 & Offshore \\
\hline 1963 & 47,191 & Offshore \\
\hline 1964 & 50,812 & Offshore \\
\hline 1965 & 41,279 & Offshore \\
\hline 1966 & 49,370 & Offshore \\
\hline 1967 & 32,491 & Offshore \\
\hline 1969 & 33,456 & Offshore \\
\hline 1974 & 10,000 & Unknown \\
\hline 1975 & 48,369 & Offshore \\
\hline 1976 & 34,691 & Offshore \\
\hline 1977 & 130,000 & Shallow-South \\
\hline 1982 & 85,396 & Offshore \\
\hline 1984 & 81,000 & Shallow-South \\
\hline 1985 & 26,180 & Shallow-South \\
\hline 1988 & 100,996 & Shallow-South \\
\hline 1990 & 49,513 & Shallow-South \\
\hline 1991 & 79,482 & Shallow-South \\
\hline
\end{tabular}




\begin{tabular}{|c|c|c|}
\hline Year & Volume (yd³) & Placement \\
\hline 1993 & 66,597 & Shallow-South \\
\hline 1994 & 44,879 & Shallow-South \\
\hline 1996 & 53,515 & Shallow-South \\
\hline 1997 & 29,000 & Shallow-South \\
\hline 1998 & 40,000 & Shallow-South \\
\hline 1999 & 61,675 & Shallow-IBSP \\
\hline 2000 & 56,275 & Shallow-IBSP \\
\hline 2001 & 56,194 & Shallow-IBSP \\
\hline 2002 & 48,623 & Shallow-IBSP \\
\hline 2003 & 30,712 & Shallow-South \\
\hline 2005 & 30,142 & $\begin{array}{c}\text { Shallow-IBSP } \\
\quad(8,300) \& \\
\text { South }(21,842)\end{array}$ \\
\hline 2008 & 71,789 & $\begin{array}{c}\text { Shallow-IBSP } \\
(60,000) \& \\
\text { South }(11,789)\end{array}$ \\
\hline 2009 & 67,820 & Shallow-IBSP \\
\hline 2010 & 60,890 & $\begin{array}{c}\text { Shallow-IBSP } \\
(29,000) \& \\
\text { South }(31,890)\end{array}$ \\
\hline 2011 & 4,000 & Shallow-South \\
\hline 2012 & 105,422 & $\begin{array}{c}\text { Shallow- } \\
\text { IBSP }(36,300) \& \\
\text { South }(69,122)\end{array}$ \\
\hline 2013 & 73,000 & $\begin{array}{c}\text { Shallow-IBSP } \\
(63,000) \& \\
\text { South }(10,000)\end{array}$ \\
\hline \multicolumn{2}{|c|}{$\begin{array}{l}\text { Total Volume 1889- } \\
\qquad 2013\end{array}$} & $3,860,458$ \\
\hline \multicolumn{2}{|c|}{ Avg Annual 1977-2013 } & 39,273 \\
\hline \multicolumn{2}{|c|}{ Avg Annual 1995-2013 } & 43,836 \\
\hline \multicolumn{2}{|c|}{ Avg Annual 2008-2013 } & 76,584 \\
\hline
\end{tabular}

Note: missing years indicate no dredging in that year or data unrecoverable. 
Table 6 lists dredging in the harbor at U.S. Naval Station Great Lakes. Large areas of the harbor shoaled soon after construction in the early twentieth century. In recent years, the harbor serves the U.S. Coast Guard and privately owned recreational boats. The entrance channel area was dredged in 2010-2011 to allow boats to reach the marina area. Volume data about previous dredging are unavailable, but during a site visit in February 2015, ERDC representatives were told the previous work was in the early 1970 . No records exist for the 1970 s work.

Table 6. Dredging, U.S. Naval Station Great Lakes.

\begin{tabular}{|l|l|c|l|l|}
\hline Date & Area & $\begin{array}{c}\text { Volume } \\
\left(\mathrm{yd}^{3}\right)\end{array}$ & Disposal & Notes \\
\hline $12 / 1 / 2009$ & $2007 \mathrm{~A}$ & 4,706 & Barge to NASCO in Chicago & North Wind 2011a \\
\hline $8 / 23 / 2010$ & $2007 \mathrm{~B}$ & 22,327 & Barge to NASCO in Chicago & North Wind 2011a \\
\hline $5 / 21 / 2011$ & FY2008 & 19,871 & Barge to Buffington & North Wind 2011b \\
\hline $6 / 9 / 2010$ & FY2009A & 31,612 & $\begin{array}{l}\text { Landfill - fine grained, } \\
\text { contaminants }\end{array}$ & $\begin{array}{l}\text { Not used in coastal budget; } \\
\text { North Wind 2011c }\end{array}$ \\
\hline 4/7/2011 & FY2009D & 5,350 & Barge to NASCO in Chicago & North Wind 2011c \\
\hline $5 / 3 / 2011$ & FY2009B & 1,962 & Barge to NASCO or Buffington & North Wind 2011c \\
\hline $5 / 31 / 2011$ & FY2009C & 12,518 & Barge to Buffington dock, Gary & North Wind 2011c \\
\hline $\begin{array}{l}\text { Total Coastal } \\
\text { Sediment }\end{array}$ & & 66,734 & Open coast (littoral) source & \\
\hline Years & & 40 & Previous dredging in $\approx 1970 s$ & \\
\hline Average & & 1,700 & & \\
\hline
\end{tabular}


Table 7 lists sand dredged from the boat ramp at Forest Park (data supplied by the Parks Supervisor, City of Lake Forest).

Table 7. Dredging, Forest Park boat ramp.

\begin{tabular}{|c|c|}
\hline Year & Volume $\left(\mathrm{yd}^{3}\right)$ \\
\hline 1995 & 2,400 \\
\hline 1996 & 2,750 \\
\hline 1997 & 2,950 \\
\hline 1998 & 3,150 \\
\hline 1999 & 2,800 \\
\hline 2000 & 2,750 \\
\hline 2001 & 2,580 \\
\hline 2002 & 2,800 \\
\hline 2003 & 2,450 \\
\hline 2004 & 2,600 \\
\hline 2005 & 2,449 \\
\hline 2006 & 2,700 \\
\hline 2007 & 2,450 \\
\hline 2008 & 2,875 \\
\hline 2009 & 2,500 \\
\hline 2010 & 2,780 \\
\hline 2011 & 2,420 \\
\hline 2012 & 2,650 \\
\hline 2013 & 2,865 \\
\hline 2014 & 1,652 \\
\hline Total: & 52,571 \\
\hline Years: & 20 \\
\hline Average: & 2,629 \\
\hline
\end{tabular}

Source: Rich Paulsen, Parks Supervisor, The City of Lake Forest, 2/11/15. 
Table 8 lists sand dredged from the Wilmette Harbor. All amounts reflect spring dredging.

Table 8. Dredging, Wilmette Harbor.

\begin{tabular}{|c|c|}
\hline Year & Volume $\left(y d^{3}\right)$ \\
\hline 1998 & 0 \\
\hline 1999 & 19,950 \\
\hline 2000 & 7,500 \\
\hline 2001 & 16,138 \\
\hline 2002 & 14,000 \\
\hline 2003 & 8,142 \\
\hline 2004 & 6,160 \\
\hline 2005 & 9,800 \\
\hline 2006 & 15,100 \\
\hline 2007 & 14,685 \\
\hline 2008 & 15,000 \\
\hline 2009 & 15,073 \\
\hline 2010 & 13,924 \\
\hline 2011 & 14,700 \\
\hline 2012 & 15,000 \\
\hline 2013 & 11,400 \\
\hline 2014 & 10,200 \\
\hline 2015 & 10,500 \\
\hline Total: & 217,272 \\
\hline Years: & 17 \\
\hline Annual: & 12,781 \\
\hline
\end{tabular}

Source: Sabine Herber, Executive Director, Wilmette Harbor Association, 11/12/2014 and 8/12/15. 


\section{Sediment Volumes and Budget}

\section{Cell WI-1, Kenosha to North Point Marina ${ }^{1}$}

This cell covers the coast north of the Illinois-Wisconsin border (Figure 8). It is outside the study area of this project but has been included because sediment moves south along the Wisconsin shore and enters North Point Marina in Illinois. The source of sediment in the littoral zone is likely beach and nearshore erosion but has not been specifically evaluated. Before development and armoring of the Wisconsin shore, erosion and transport contributed several tens of thousands of cubic yards per year to the littoral transport (Chrzastowski and Frankie 2000). Construction of shore defenses along much of the coast south of Kenosha, and the dredging and removal of littoral sand at the entrances to Kenosha Harbor and Prairie Harbor Marina (constructed in the late-1980s) on the Wisconsin side of the state line have significantly reduced the quantity of littoral sediment reaching the Illinois shore. Foyle, Chrzastowski, and Trask (1998) estimated that only 10,000 yd3/year of littoral material crossed the state line. Before construction of the North Point Marina, a "best estimate" was considered to be 60,000 to $80,000 \mathrm{yd} 3 /$ year, but based on the monitoring of geomorphic changes at North Point Marina, Chrzastowski (2003) estimated that a minimum of 16,000 yd $3 /$ year crossed into Illinois. Based on the monitoring by Chrzastowski (2003), the amount of sand moving south for this budget is also estimated to be $16,000 \mathrm{yd} 3 /$ year. This rate is the best available estimate of sediment flux across the state-line. However, this value likely needs to be updated as updrift shore protection structures and sand management activities may have reduced nearshore sand availability. In the future, if the sediment volume crossing the state line is recomputed, the rest of the sediment budget farther south can be adjusted accordingly. The following paragraphs provide additional information about the values included in the sediment budget.

\footnotetext{
1 Cell number is used for reference when referring to Appendix A.
} 
Figure 8. Sediment budget north zone, from the WI-IL border to Waukegan Harbor. All units in $\mathrm{yd}^{3} /$ year; $\Delta V=$ net change in volume within the cell; $\mathrm{R}=$ amount of material removed from the cell, usually by dredging; $P=$ amount of material placed in the cell. Details of the Waukegan area are shown in Figure 13. Background map from ESRI Maps and Data.

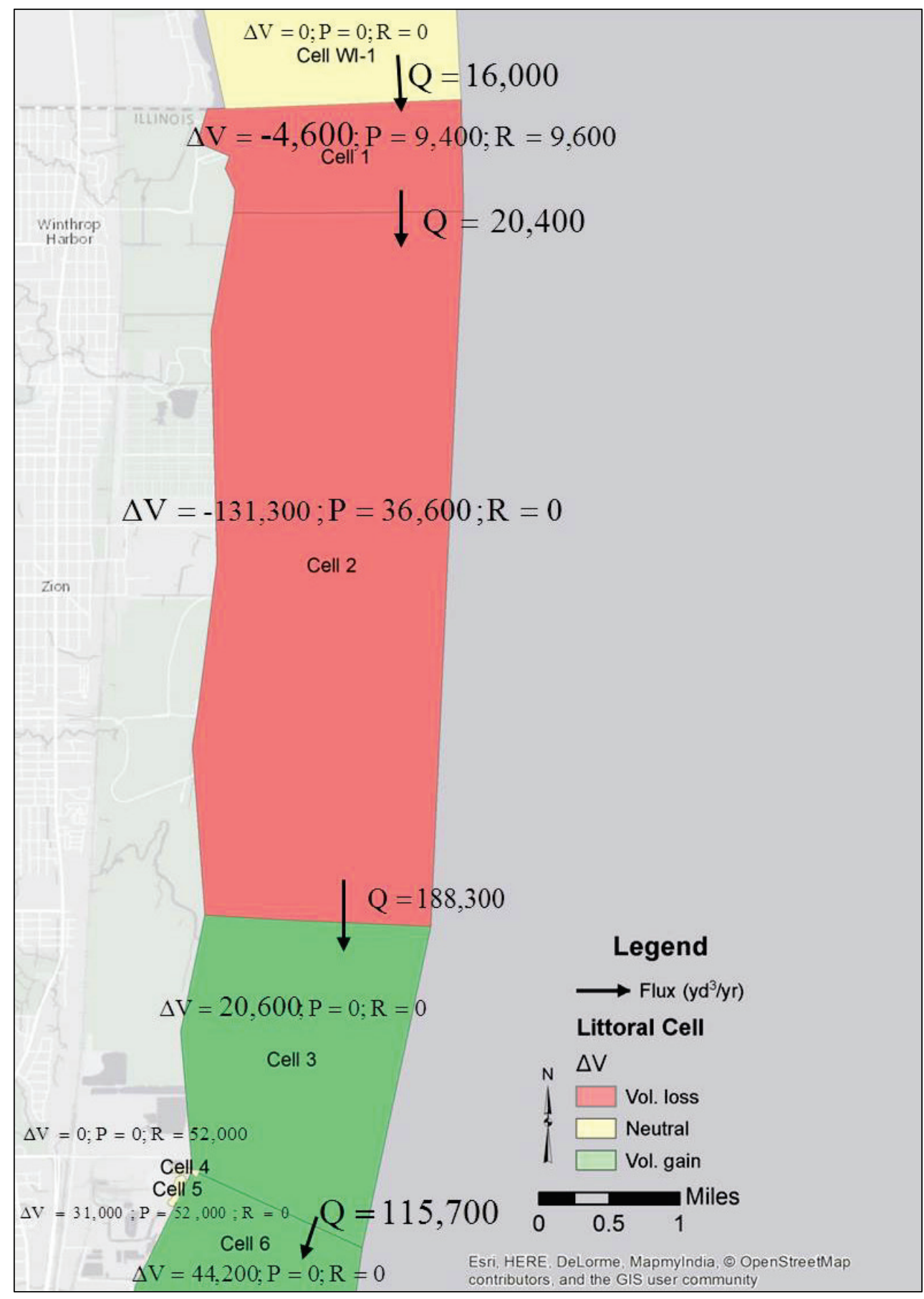




\section{Cell 1, North Point Marina}

The marina is operated by the IDNR and is the largest recreational marina in the Great Lakes. Construction began in 1987, and the project was completed by 1989, making this the most recent major coastal structure to be added to the Illinois coast (Chrzastowski and Trask 1996a;

Chrzastowski 2003). Two arcuate rubble-mound breakwaters protect the perimeter of the marina basin, and the north breakwater forms a partial barrier to littoral transport. Sand that bypasses this breakwater accumulates in the marina entrance and is removed with mechanical equipment. The average annual removal is $9,600 \mathrm{yd}^{3}$, and the sand is placed downdrift (south) adjacent to the parking lot (Figure 9 and Table 3). Shortly after marina construction, the feeder beach to the south was reassigned to become a parking area. Shore defense was built, and additional sand was imported to serve as a substitute feeder beach.

Chrzastowski et al. (1996; p. 17) listed the import of 150,000 yd 3 in 1990, $32,000 \mathrm{yd}^{3}$ in 1994 , and $53,000 \mathrm{yd}^{3}$ in 1995 -early-1996. For estimating the $P$ term in the sediment budget, the volume was averaged over the period 1990-2015, amounting to $9,400 \mathrm{yd} 3 /$ year.

Offshore, sediment has accumulated north of the north jetty but had been lost adjacent to the marina and to the south (Figure 7). Lakebed change $(\Delta V)$ is only $-4,600 \mathrm{yd} 3 /$ year (see Appendix A for details of this and all other cells). 
Figure 9. Sand dredged from the entrance channel at North Point Marina is piled south of the entrance and pushed into the lake. Photograph 17 June 2014.

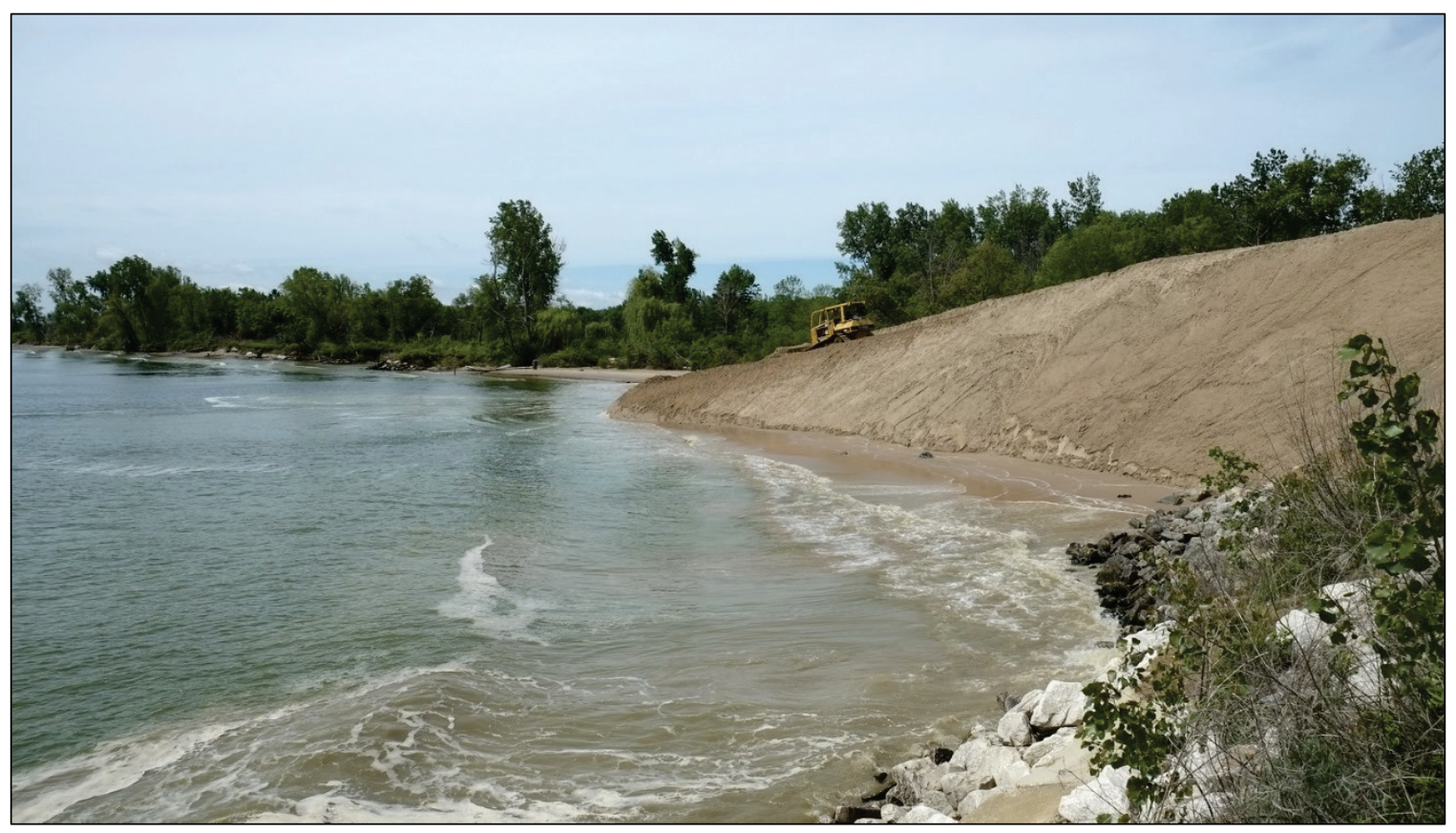

\section{Cell 2, Illinois Beach State Park north zone}

Illinois Beach was legally designated as a state park on 13 July 1953. Prior to park designation, the land had a diverse history and saw a variety of uses. The initial designation as a park was for what is now the South Unit, while the North Unit has existed for approximately 40 years following land acquisitions by the State of Illinois in the 1970s (Chrzastowski and Frankie 2000). As described earlier, this stretch of the Illinois Coast is least anthropogenically disturbed; however, the beach continues to suffer erosion from storm waves (Figure 10). Two cells cover the shore along the IBSP. The northern cell includes the zone with the greatest lakebed sediment loss, with $\Delta V=-131,300 \mathrm{yd} 3 /$ year. USACE has placed an average of 27,000 yd3/year of dredged material from Waukegan Harbor (1995-2013) in the nearshore area of the Illinois Beach State Park (USACE 2014). Additionally, IDNR has placed 9,600 yd3/year of dredged material from North Point Marina and brought in additional sources via trucks to a feeder beach that is south of the marina. 
Figure 10. Illinois Beach State Park, with scarp formed by storm waves. Photograph 17 June 2014.

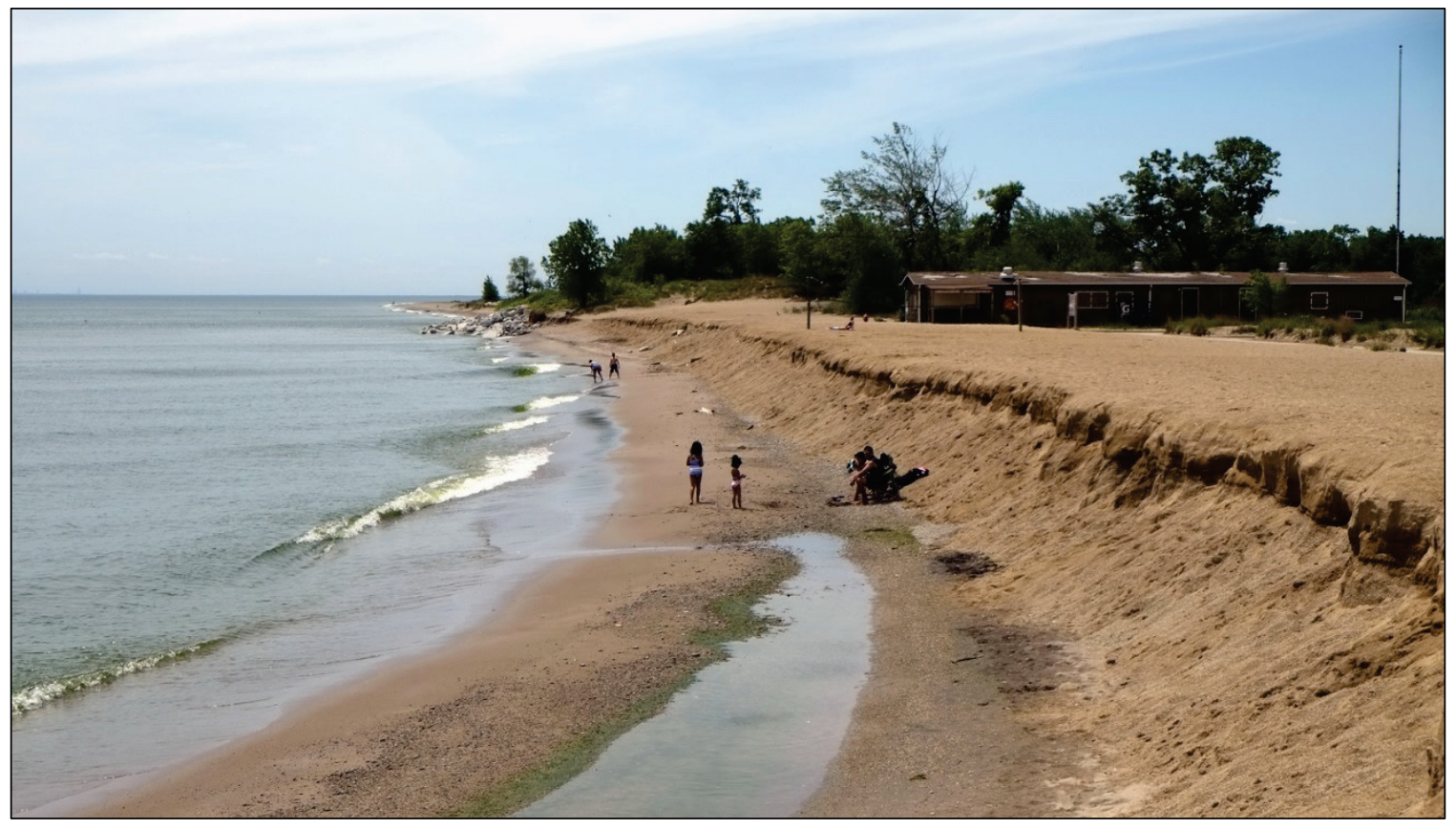

\section{Cell 3, Illinois Beach State Park south zone}

The southern part of IBSP has experienced minimal lakebed loss with mainly areas of accretion as compared to the north zone, with $\Delta \mathrm{V}=$ $20,600 \mathrm{yd} 3 /$ year. Analysis of dredging histories suggests that from the south end of this cell, 52,000 yd3/year of sediment enters the cooling water canal at Waukegan Electric Generating Station while 115,700 $\mathrm{yd} 3 /$ year continues south to the fillet north of the Waukegan Harbor north jetty.

\section{Cell 4, Waukegan Electric Generating Station intake canal}

Two canals lead from the Waukegan Electric Generating Station into Lake Michigan. The warm water outlet canal is self-flushing, but the cooling water intake canal requires regular clearing. Annual dredging for the period 1995-2014 was 52,000 yd3/year. This value has been used in the sediment budget (Figure 8). Because of State of Illinois regulations, presently this sand cannot be returned to the open coast and must be stockpiled on land due to the presence of asbestos fibers sourced from homes that were destroyed by erosion in the area now occupied by North Point Marina. 


\section{Cell 5, Waukegan Electric Generating Station sand pile}

The sand pile contains approximately $600,000-630,000 \mathrm{yd}^{3}$ of sand (Figure 11 and Figure 12). The volume was calculated two ways: (1) geometrically based on the footprint and height and (2) via a sand pile calculator: http://www.had2know.com/garden/calculate-volume-pile-gravel.html. For this analysis, a volume of $620,000 \mathrm{yd} 3$ total has been used. The pile has compressed over time (F. Veenbaas, NRG Energy, personal communication, 15 July 2015). Over 20 years, $\Delta V=31,000$ yd $3 /$ year. Because placement has been $52,000 \mathrm{yd} 3 /$ year, approximately $21,000 \mathrm{yd}^{3}$ is lost annually. A reasonable assumption is that approximately half, or 11,000 yd3/year, has been lost to Aeolian transport and 10,000 yd3/year to compression (Figure 13).

Figure 11. Sand pile at Waukegan Generating Station. Photograph 17 June 2014.

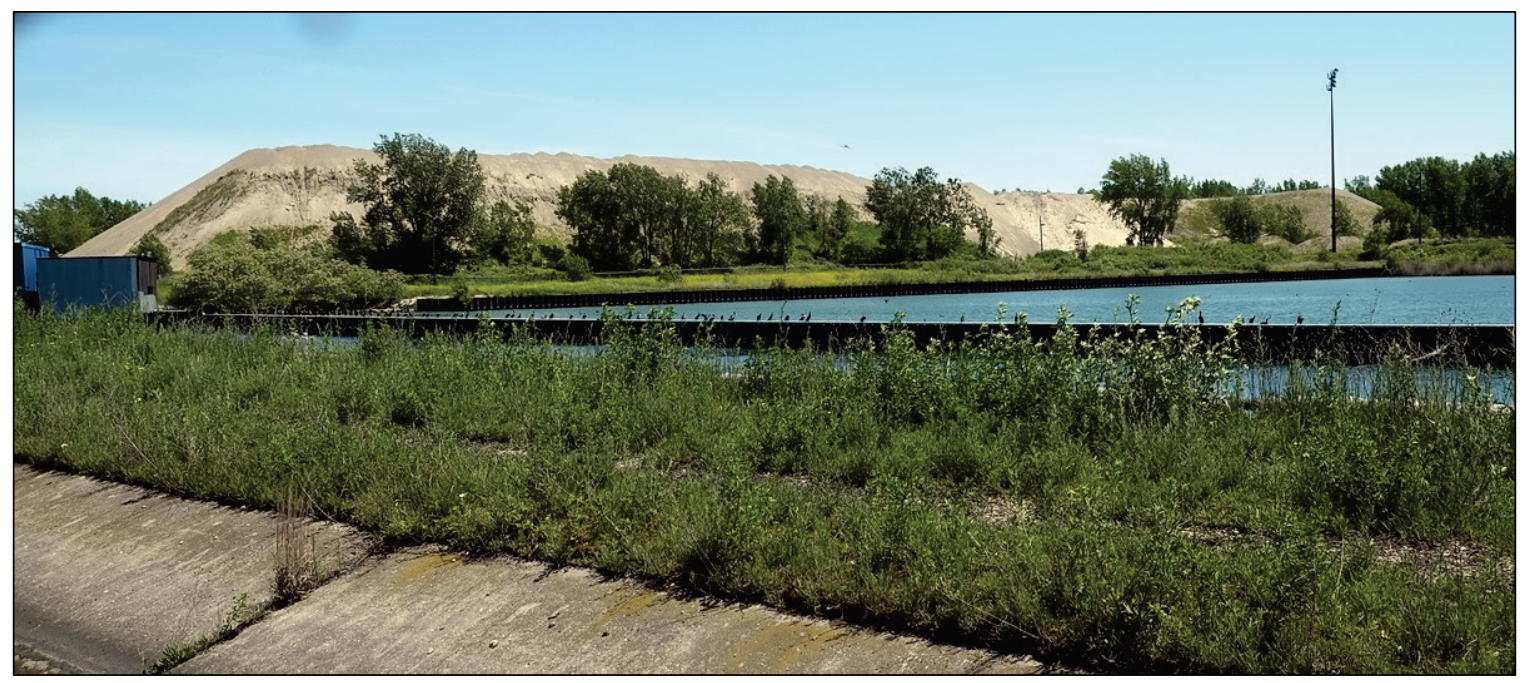


Figure 12. Dredged sand pile at Waukegan Generating Station. Top of the pile is unvegetated.

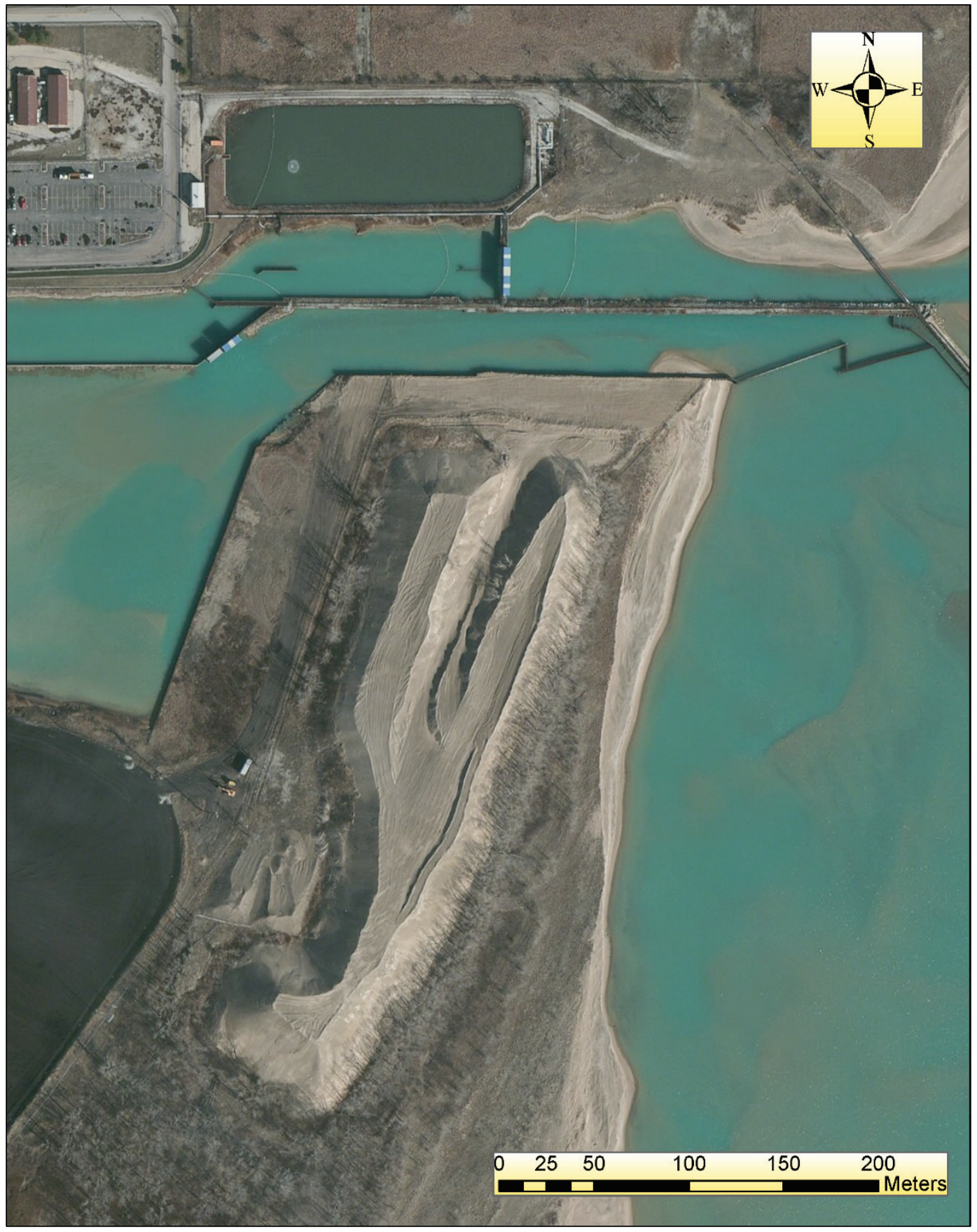


Figure 13. Sediment movement near Waukegan Generating Station and Waukegan Harbor. All units in $\mathrm{yd}^{3} /$ year; $\Delta V=$ net change in volume within the cell; $R=$ amount of material removed from the cell, usually by dredging; $P=$ amount of material placed in the cell. Background map from ESRI Maps and Data.

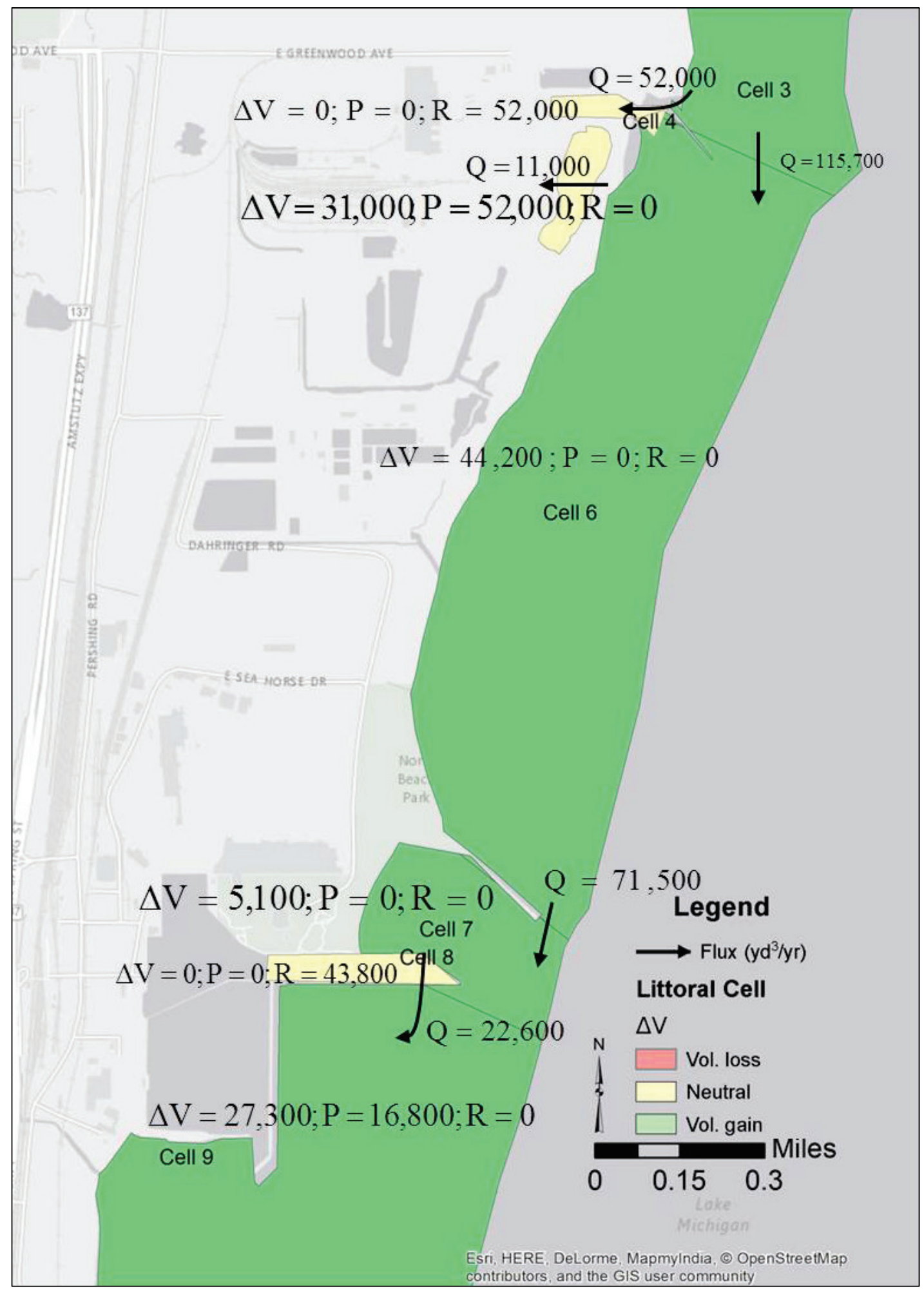




\section{Cell 6, Waukegan Electric Generating Station to Waukegan north fillet beach}

At ISGS Transect 222, just north of the base of the north jetty (Figure 14), total beach advance since 1873 was 2,700 ft. To determine the recent sediment budget, the 2012 lidar dataset along with $3 \%$ of the 2008 cells were compared with the 1976 contour map. This area has predominately accreted, with $\Delta V=44,200 \mathrm{yd}^{3} /$ year. From the south end of this cell, $71,500 \mathrm{yd} 3 /$ year of sediment continues south to the Waukegan Harbor beach fillet.

Figure 14. Historical bluff edges north of Waukegan Harbor based on ISGS data. The blue points are a hypothetical 1987 beach shoreline.

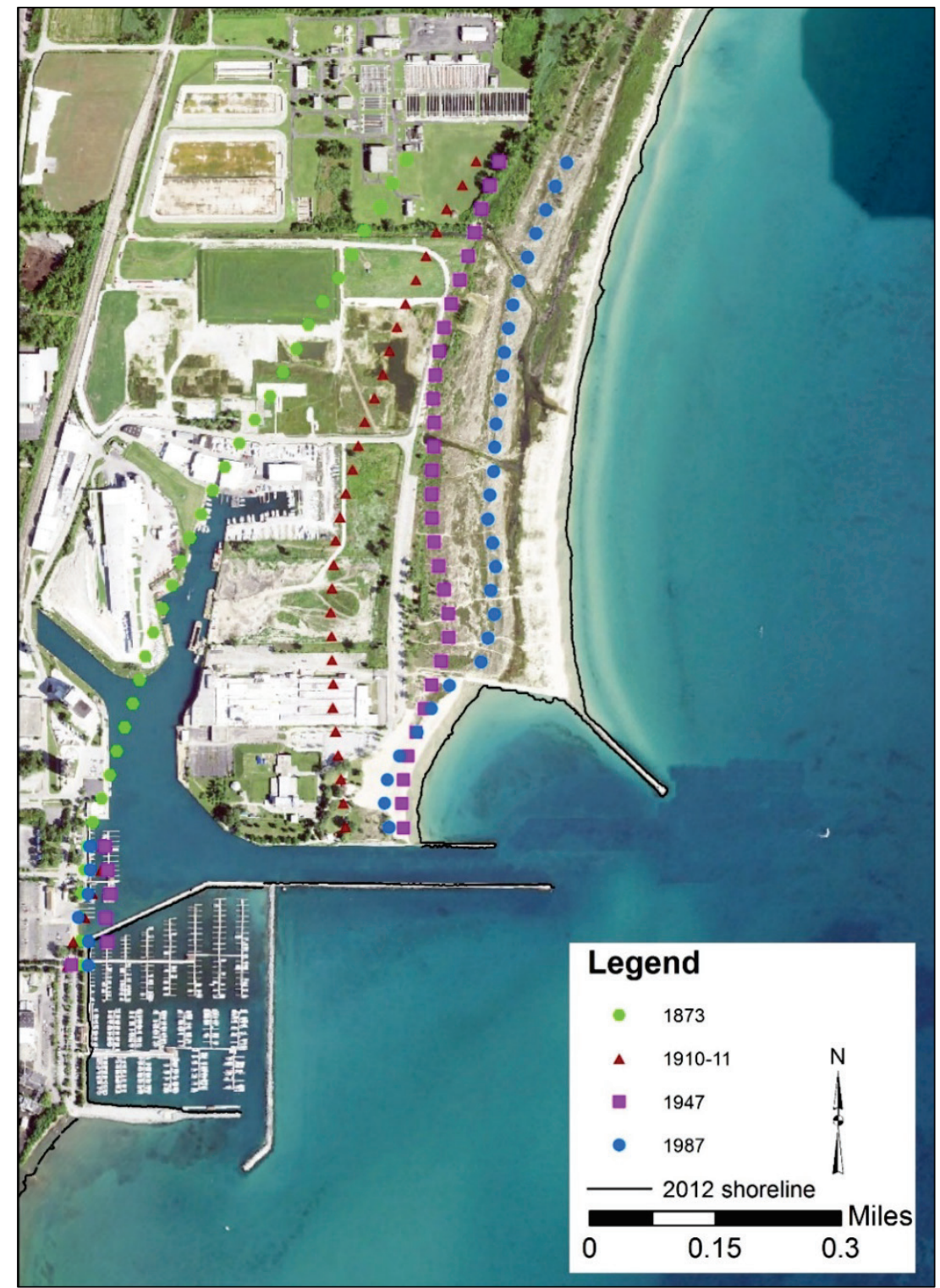




\section{Cell 7, Waukegan Harbor beach fillet}

The fillet beach north of the jetty has been accumulating sand that has been trapped by the north jetty since the late 1800 . To determine the recent sediment budget, the 2012 lidar dataset along with $5 \%$ of the 2008 lidar values were compared with the 1976 contour map. This area has predominately accreted, with $\Delta V=5,100 \mathrm{yd} 3 /$ year. From the south end of this cell, 22,600 $\mathrm{yd} 3 /$ year of sediment continues south along the open coast to Cell 9 after an average yearly removal of $43,800 \mathrm{yd} 3 /$ year from Waukegan Harbor (Cell 8).

\section{Cell 8, Waukegan Harbor}

Waukegan is a deep-draft federal harbor, and the USACE is responsible for maintaining authorized navigation depths in the entrance channel. Federal participation in the harbor began in 1852 with construction of an offshore breakwater, but it was rapidly destroyed in storms. Construction of the north and south piers began in 1881 and over the years, were progressively lengthened and renovated (see Chrzastowski and Trask [1996a] for more historical details). Annual dredging increased as the fillet beach reached capacity and sand wrapped around the north breakwater and entered the navigation channel (Figure 15). This sediment budget uses the $1995-2013$ average value of 43,800 yd3/year (Table 5). Of this amount, 27,000 yd $3 /$ year has been bypassed to the north to the IBSP while 16,800 yd3/year has been placed south in shallow water off North Chicago. 
Figure 15. Waukegan Harbor north breakwater, view looking east. Shallow lakebed on the north side of the pier is demonstrated by the bathers standing in shallow water left of the structure. Photograph 17 June 2014.

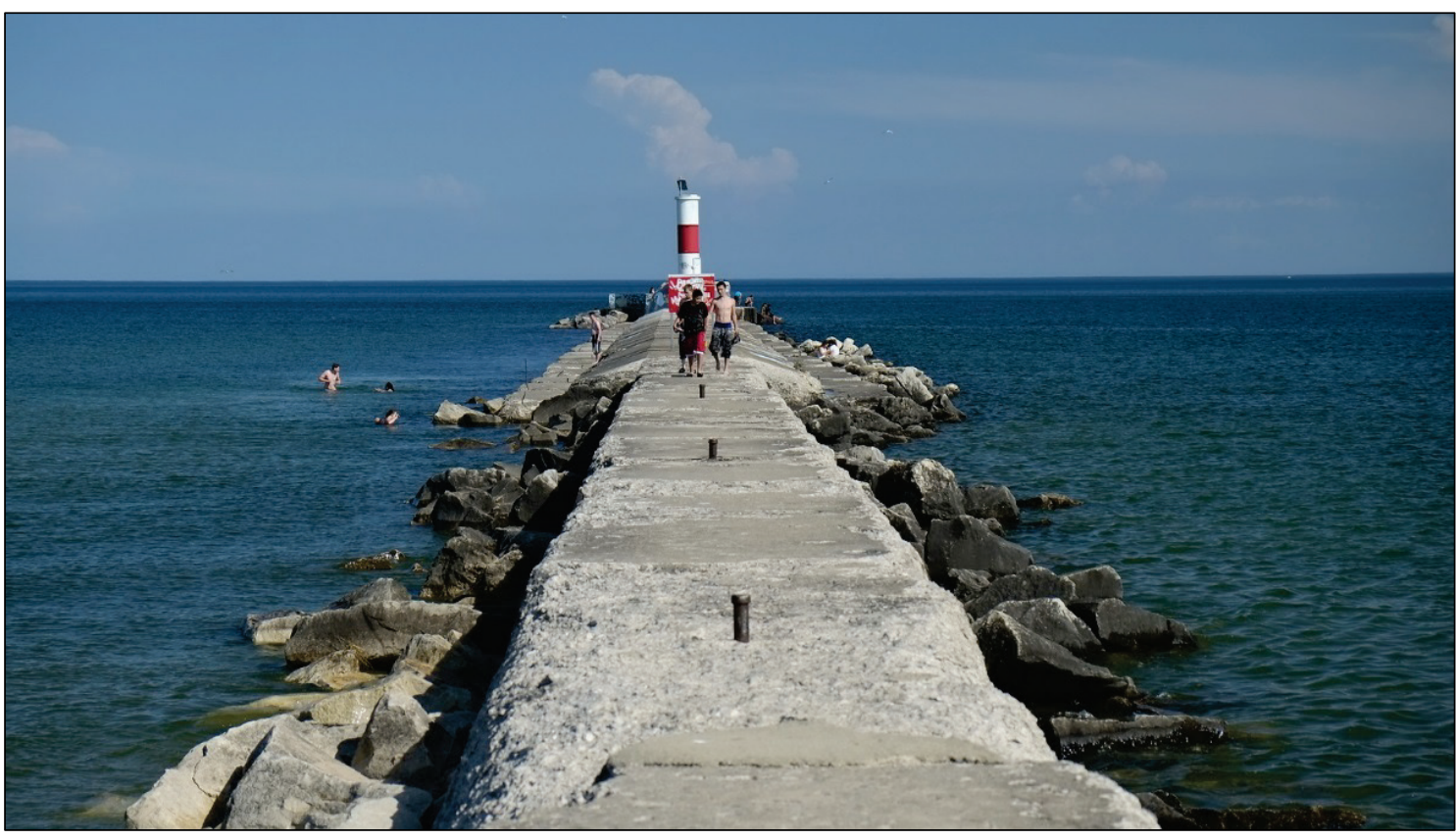

\section{Cell 9, Waukegan to U.S. Naval Station Great Lakes north fillet}

This cell extends from just south of Waukegan Harbor to the fillet north of U.S. Naval Station Great Lakes. Sand has been bypassing the mouth of Waukegan Harbor for several decades (Chrzastowski and Trask 1996a), and an accumulation of sand on the lake bed south of the harbor mouth was interpreted as this bypassing feature (Figure 16). The volume of the plume was measured as 27,300 yd3/year, based on comparing the 1974/1975 acoustic surveys and the 2012 lidar with $1 \%$ of cells from the 2008 lidar dataset in the area of the plume that is delineated in Figure 16. The lakebed outside the plume area was glacial till. Therefore, as described earlier, only $5 \%$ of this volume contributed sand to the littoral system while the $95 \%$ fine material was lost. This $5 \%$ sand was measured as $600 \mathrm{yd} 3 /$ year. The amount mechanically bypassed from Waukegan harbor dredging was $16,800 \mathrm{yd} 3 /$ year and is represented in Figure 16 by the black hatched box. 
Figure 16. Elevation changes 1974/1975 - 2012 on the lakebed south of Waukegan harbor. The green plume extending south from the harbor mouth represents sand bypassing (outlined in purple). The placement site for material dredged from Waukegan Harbor is represented by the black hatched box south of the sand bypassing plume.

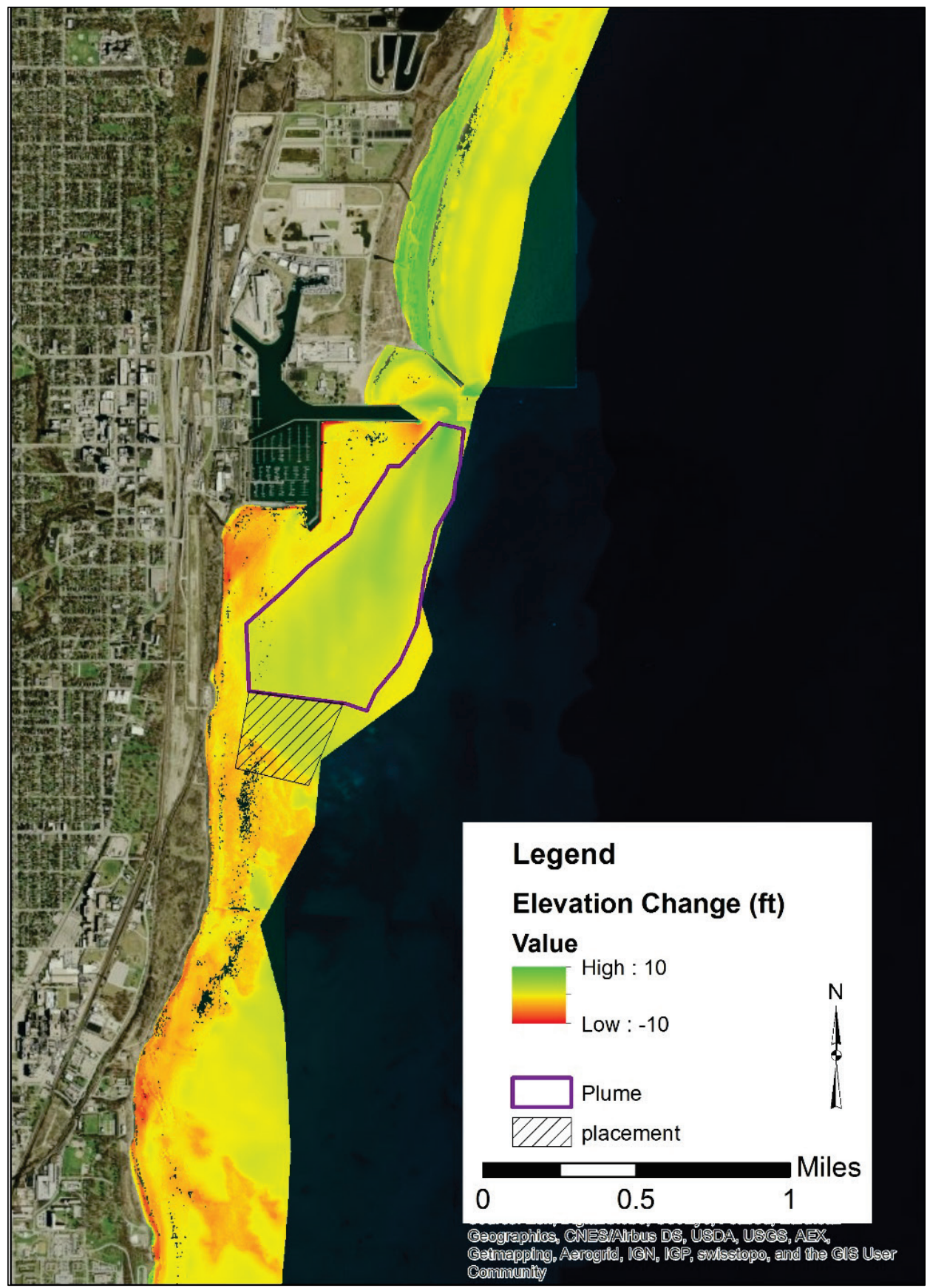

\section{Cell 10, U.S. Naval Station Great Lakes fillet}

The fillet at U.S. Naval Station Great Lakes has been filled to capacity since the 1970 or 1980 s (Chrzastowski and Trask 1996a). Therefore, $\Delta V$ is extremely small at $-100 \mathrm{yd} 3 /$ year as calculated using the 2012 lidar dataset 
with $3 \%$ of the values from the 2008 lidar dataset compared with the 1976 contours. Also, the assumption of $5 \%$ sand being available to the littoral system was included for this cell. Sand that enters the cell from the north either enters the harbor $(1,700 \mathrm{yd} 3 /$ year $)$ or bypasses to the south 12,800 yd3/year (Figure 17).

Figure 17. North Illinois sediment budget, central section, from Waukegan to Fort Sheridan. All units in $\mathrm{yd}^{3} /$ year; $\Delta \mathrm{V}=$ net change in volume within the cell; $\mathrm{R}=$ amount of material removed from the cell, usually by dredging; $P=$ amount of material placed in the cell.

Background map from ESRI Maps and Data.

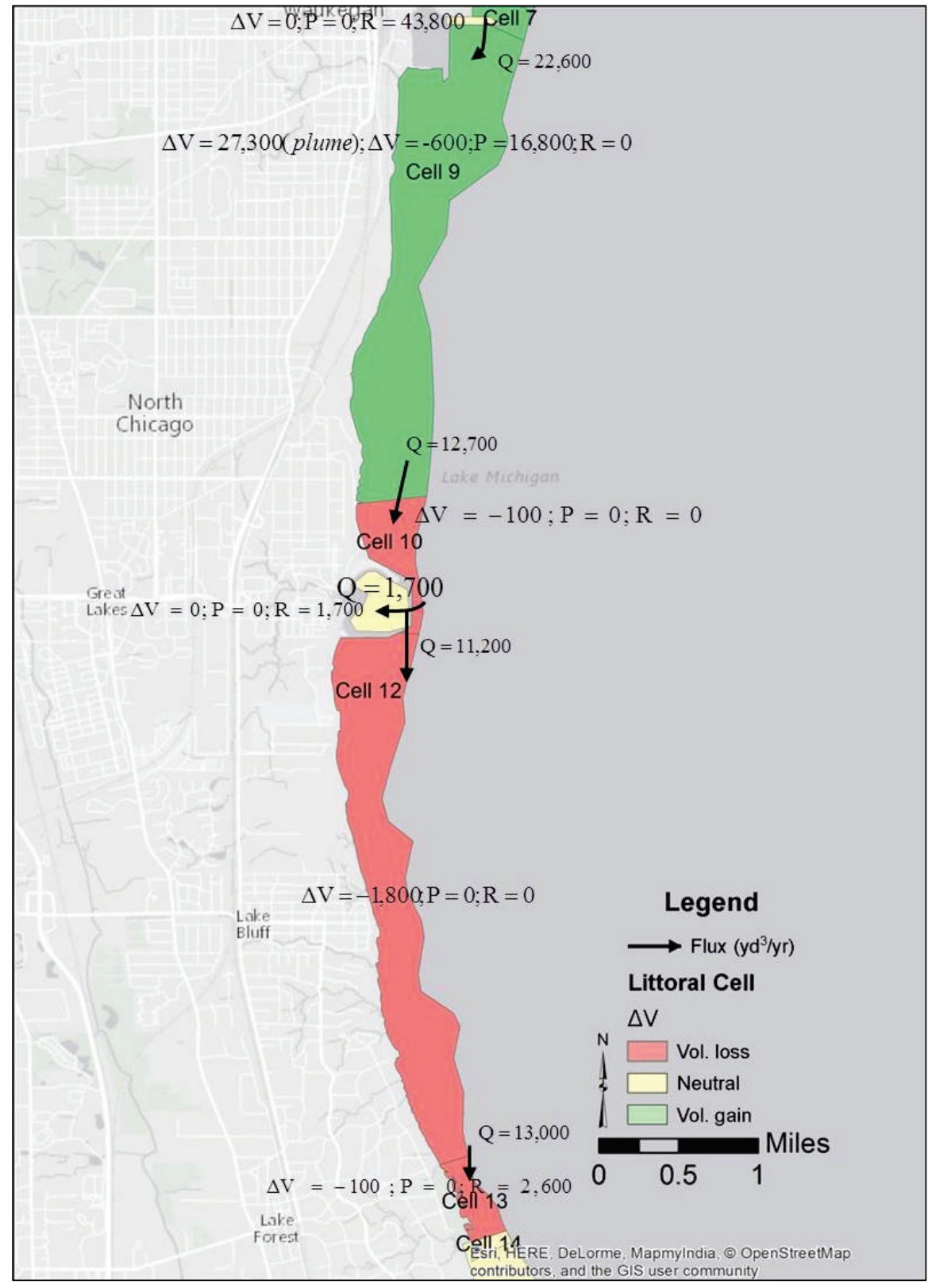




\section{Cell 11, U.S. Naval Station Great Lakes Harbor}

U.S. Naval Station Great Lakes is the U.S. Navy's only boot camp for recruits. The site covers 193 acres and includes numerous historical buildings erected between 1905 and 1911. Originally, the harbor consisted of two piers or groins built in 1910 that enclosed the mouth of Pettibone Creek (Figure 18). Sailors trained in the enclosed anchorage. The present outer breakwaters (Figure 19) were built in 1923. Sand rapidly accumulated in the fillet to the north and entered the harbor, and the enclosed harbor south of the north jetty is partly emergent.

Figure 18. Painting of U.S. Naval Station Great Lakes, circa pre-1923 (photographed from display prepared by Illinois Work Projects Administration, War Services). The present outer jetties are not shown in this painting. The north breakwater now extends out from the shore at approximately the power station.

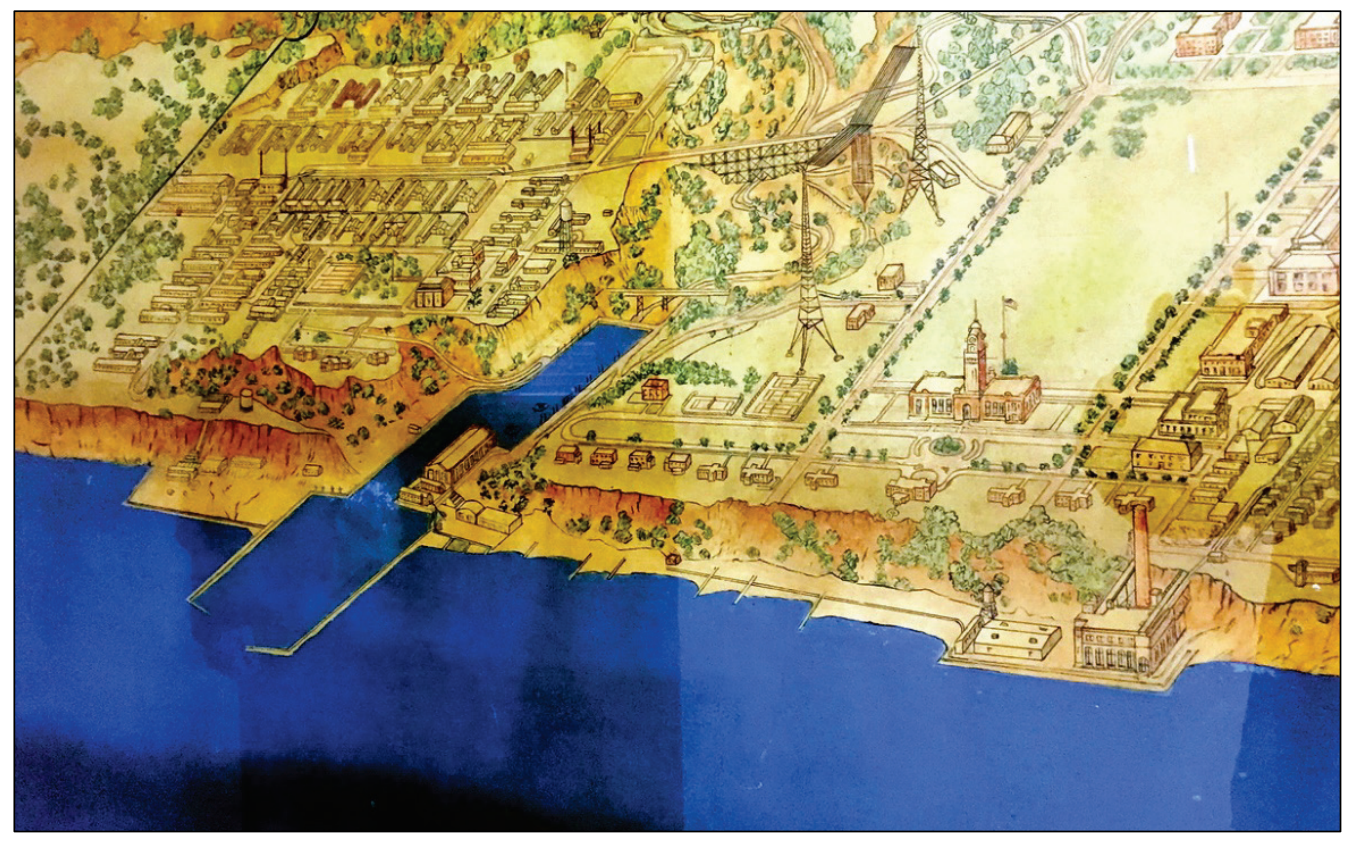


Figure 19. U.S. Naval Station Great Lakes, oblique view from Google Earth showing approximately the same view as Figure 18. Photograph June 2015. The bluffs are vegetated and not obvious in this photograph.

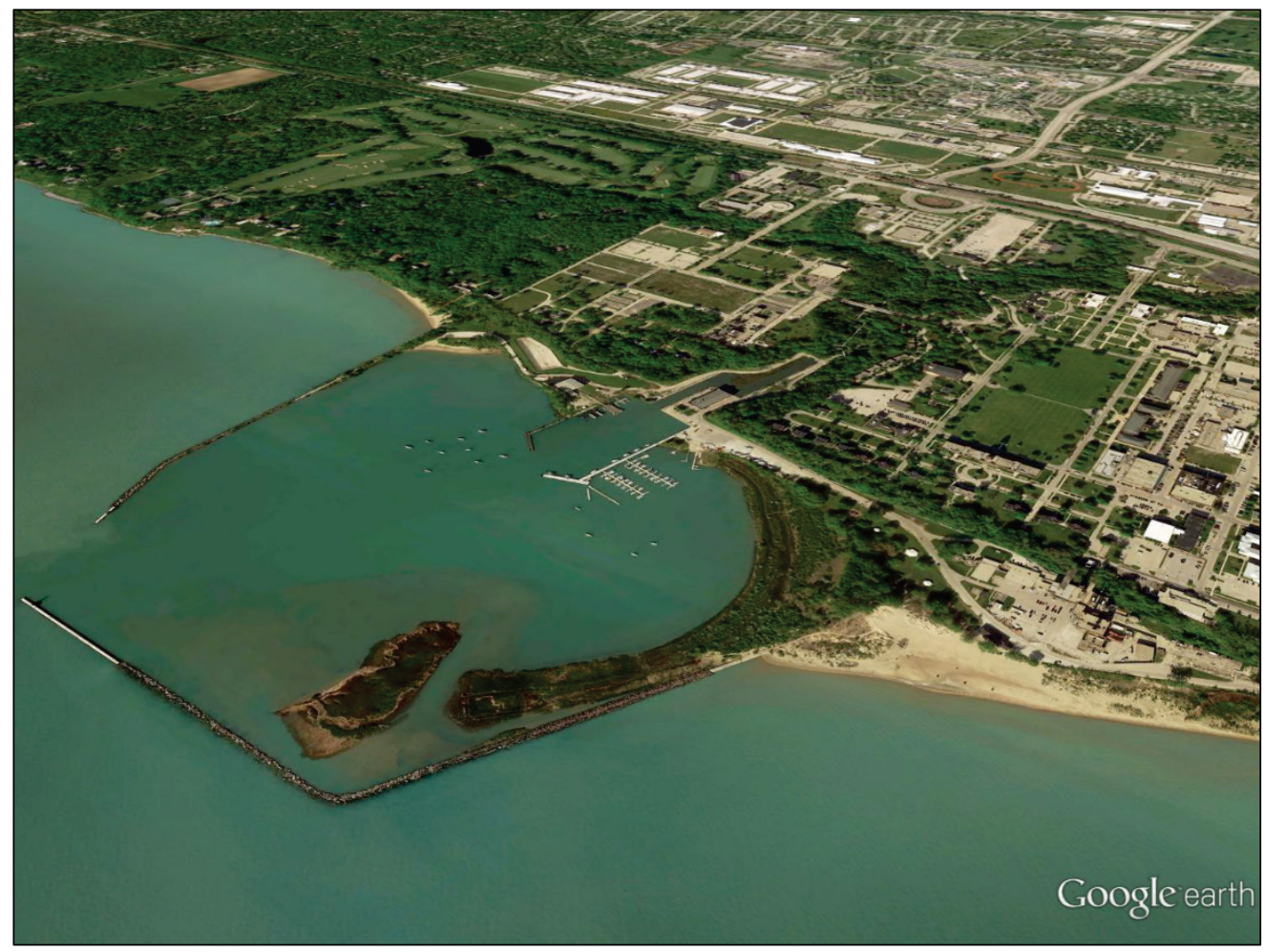

No documents pertaining to previous dredging have been located, but the authors were told that the outer harbor had not been dredged since the 1970s (Harvey Pokorny, Environmental Project Manager, NAVFAC MIDLANT, personal communication, 11 March 2015). The entrance channel and select areas were dredged in 2009-2011, with the material barged to Indiana for beneficial use including roadway construction (North Wind 2011a,b,c). For the sediment budget, the time interval is assumed to be 40 years, and $R=1,700 \mathrm{yd}^{3} /$ year. $Q$ was assumed to be this same amount because aerial photographs over time show that the exposed shoals and marsh within the northern part of the harbor have not appreciably changed for two or three decades. The harbor does not appear to be a major sediment sink now.

In 2010, 31,600 yd 3 of fine grained material was removed from the mouth of Pettibone Creek. This was disposed on land and has not been included in the sediment budget calculations. 


\section{Cell 12, U.S. Naval Station Great Lakes to Forest Park}

Sand in this cell south of the mouth of the U.S. Naval Station was computed using the 2008 lidar dataset since $77 \%$ of the pixels in the cell were null for the 2012 lidar dataset. The computed value is $-1,800 \mathrm{yd} 3 /$ year when using the assumption to include $5 \%$ as littorally available sand. Historically, this stretch of coast received minor input from bluff recession. The flux $(Q)$ out of this cell to the south is calculated as 13,000 yd3/year.

\section{Cell 13, Forest Park Beach}

Forest Park Beach, in the City of Lake Forest, is protected with three stone shore-parallel breakwaters and a fourth section to the south with southfacing arm that encloses a boat ramp. The breakwaters were designed to contain crescent-shaped recreation beaches, which curve out to the breakwaters, forming tombolos (Figure 20). Chrzastowski and Trask (1996b) intensively surveyed the four-cell breakwater system between 1991 and 1995. A sand deficit was caused by the development of a sand bridge around the breakwater system, but there was no evidence of adverse impacts to downdrift properties. Annual sand removal is 2,600 $\mathrm{yd} 3$ (Table 7). This is placed to the south. A negligible amount of volumetric change was calculated for this cell (-100 yd3/year), and therefore the flux to the south is $10,500 \mathrm{yd} 3 /$ year.

Figure 20. Forest Park Beach, City of Lake Forest. The shore-parallel breakwaters protect crescent-shaped beaches. Photograph 17 June 2014.

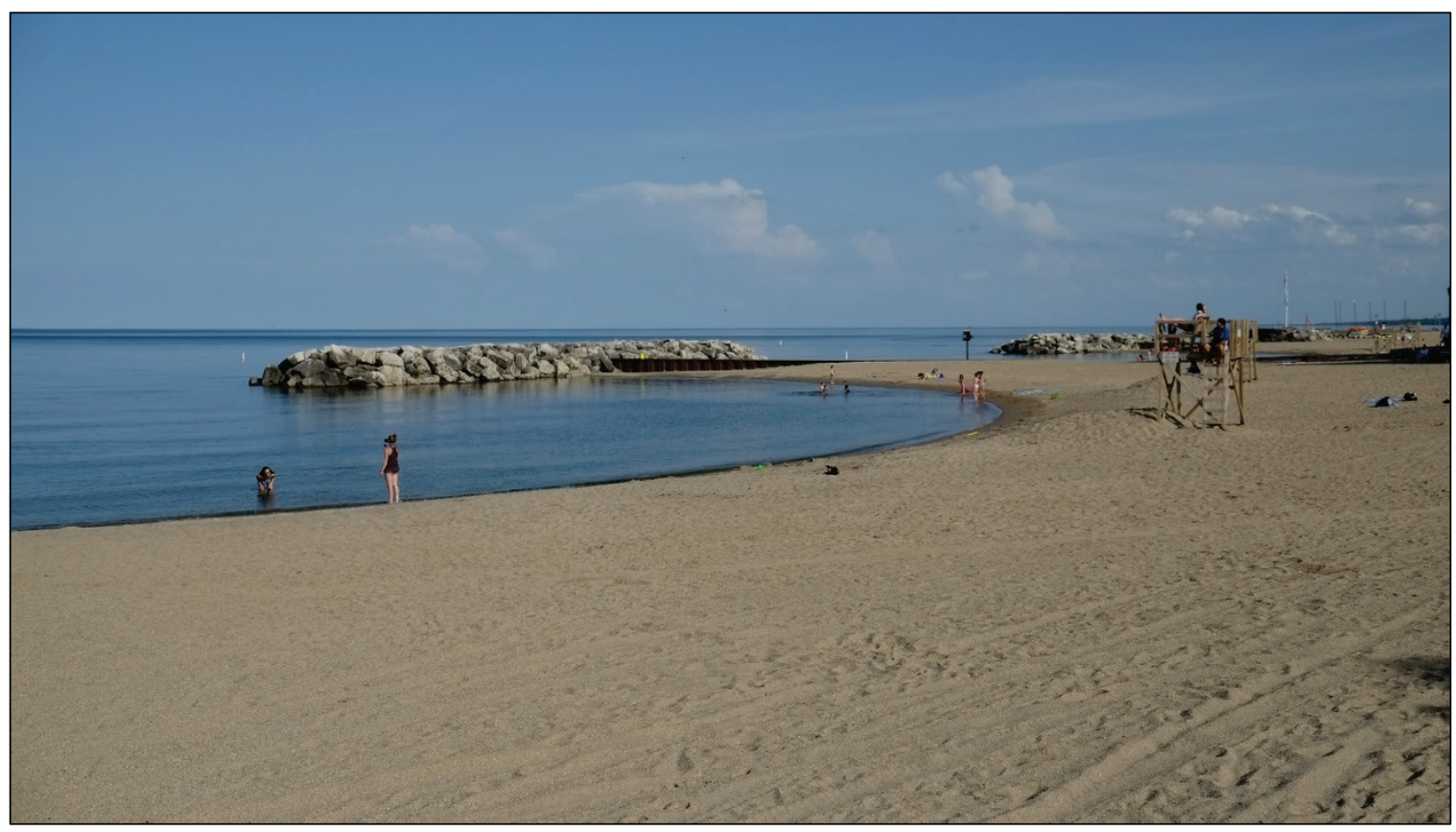




\section{Cell 14, Forest Park to Winnetka water plant}

This long cell extends from Lake Forest to the water plant at Winnetka (Figure 21). The bluffs along this cell have been armored, and a comparison with ISGS bluff edge data and 2012 lidar indicates essentially no bluff retreat in recent decades (Figure 4). Therefore, sediment input from the bluff was treated as zero. The beaches along this shore have been sand-limited for decades, and groins built decades ago attest to the attempt by homeowners to preserve the limited amount of sand that did exists (Figure 22). A fillet beach has accumulated north of the pier at the Winnetka water plant. Historical shoreline data were not available at this site, but an examination of photographs on Google Earth Pro showed minor shoreline changes between 2002 and 2015. Placement from the Forest Park boat ramp is $2,600 \mathrm{yd} 3 /$ year, and flux to the south is 13,100 yd3/year. 
Figure 21. North Illinois sediment budget, southern section. All units in $\mathrm{yd}^{3} / \mathrm{year} ; \Delta V=$ net change in volume within the cell; $R=$ amount of material removed from the cell, usually by dredging; $P=$ amount of material placed in the cell. Background map from ESRI Maps and Data.

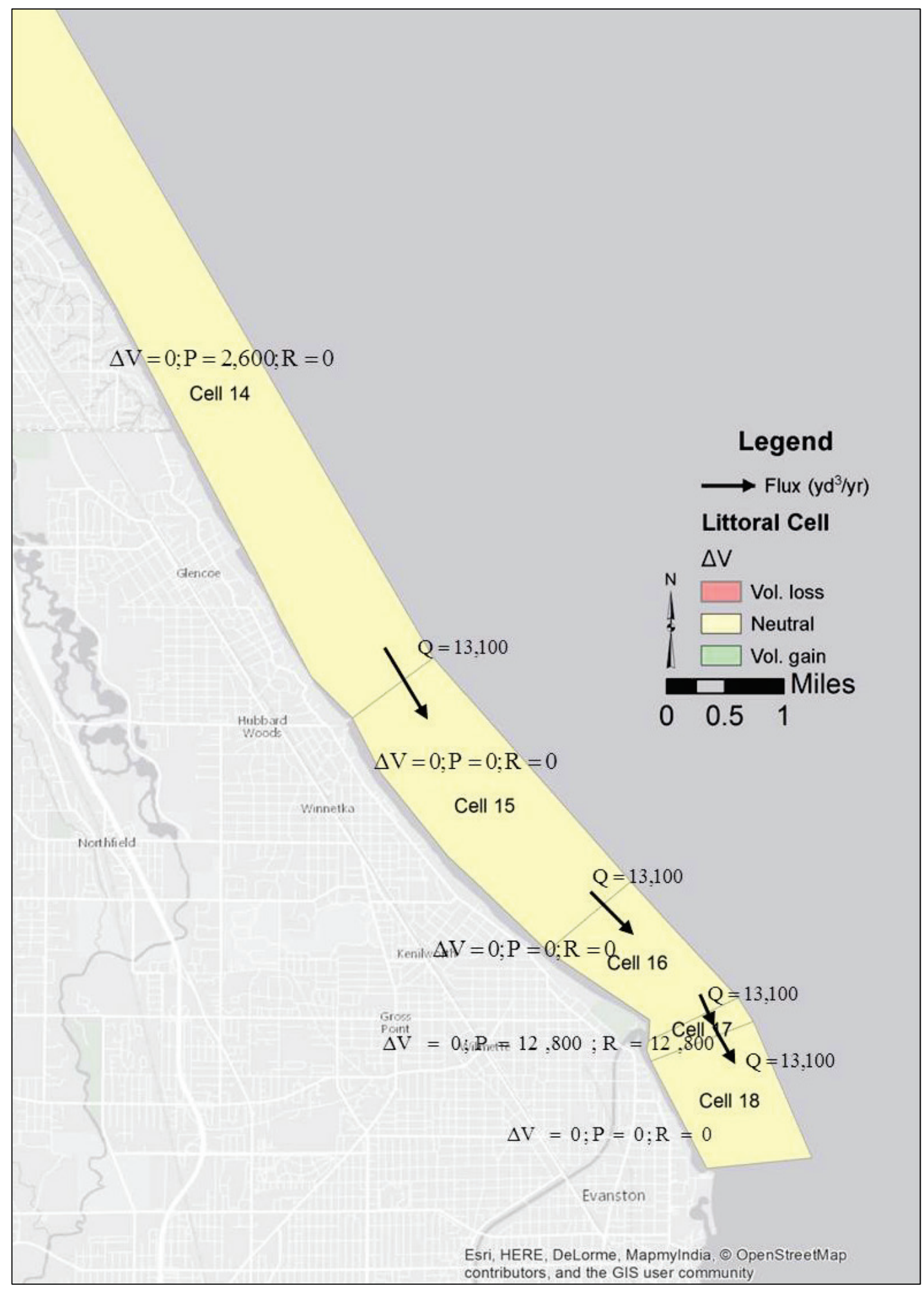


Figure 22. Shore protection at base of Harbor Street, Village of Glencoe, view looking south, November 1945 (photograph from the archives of the Beach Erosion Board, USACE).

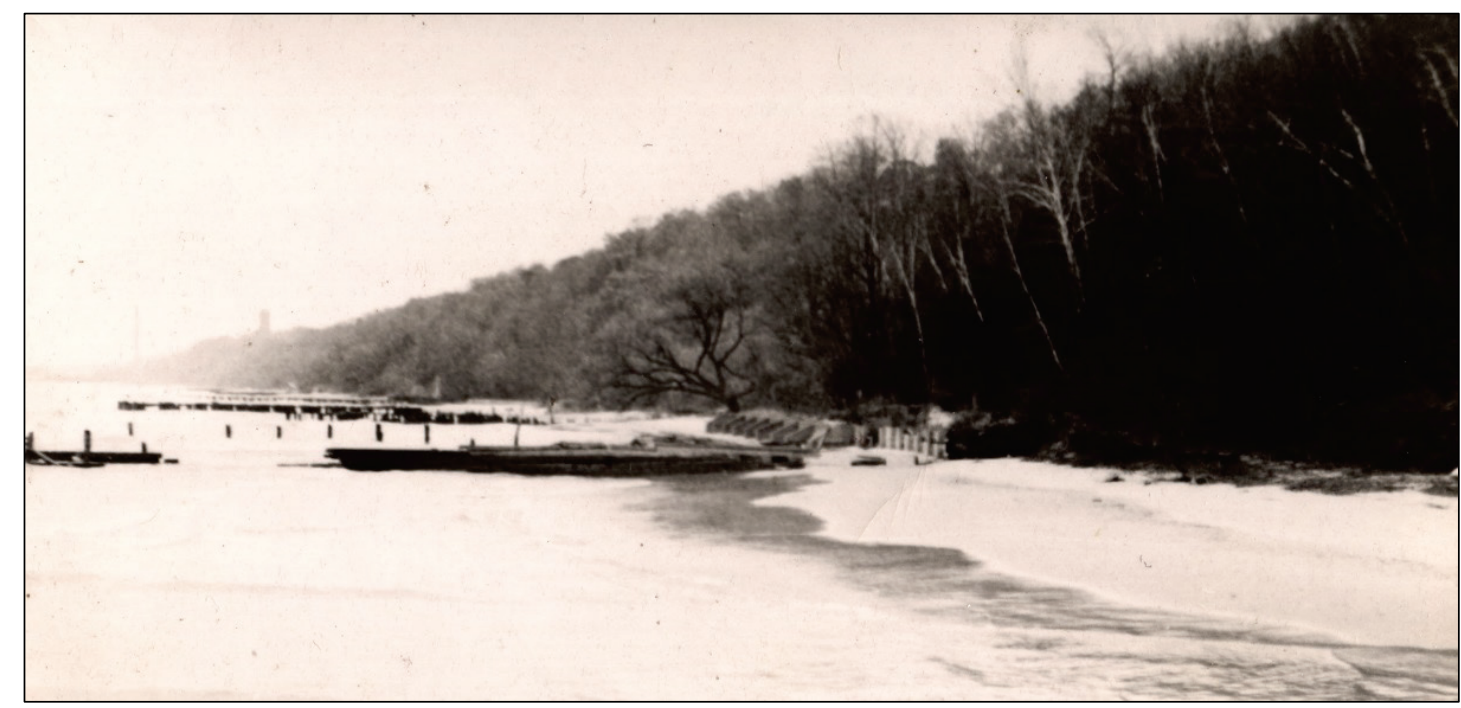

\section{Cell 15, Winnetka water plant to Gillson Park}

This section of coast has minimal sand on the upper shoreface. The entire reach is armored, with a variety of structures. Based on aerial photographs, some groins are partly sand-filled while other sections have stone riprap directly at the water's edge. $\Delta V, P$, and $R$ are zero in this cell. The flux was computed based on dredging at Wilmette and equals $13,100 \mathrm{yd} 3 /$ year.

\section{Cell 16, Gillson Park}

This cell covers Gillson Park. The park, which is operated by the Wilmette Park District, offers 60 acres of lakefront property, with swimming and other recreation facilities. The southern end of the beach is anchored by a stone groin approximately $400 \mathrm{ft}$ north of the pier that marks the entrance to Wilmette Harbor (Figure 22).

Shoreline data were not available for the beach, and Google Earth Pro historical photographs did not show a long-term pattern of beach change. Therefore, $\Delta V$ is assumed to be zero, and flux into this cell is equal to flux out $(13,100 \mathrm{yd} 3 /$ year $)$.

\section{Cell 17, Wilmette Harbor and beach}

Wilmette Harbor, which serves recreational boats, is located at the end of the North Shore Channel. The channel, dug between 1907 and 1910, 
provides flushing to the north branch of the Chicago River. The U.S. Coast Guard has a station in Wilmette Harbor.

Average annual dredging at the harbor for the period 1998-2015 was $12,800 \mathrm{yd}^{3}$. This value is consistent with historical volumes. Shabica et al. (2004; citing a personal communication from the former Wilmette Harbor Master, Mr. William Z. Wente) listed longshore transport to be from 10,000 to $15,000 \mathrm{yd} 3$ /year based on late 20 th century dredge records.

Sand dredged from Wilmette Harbor is placed offshore of the beach south of the harbor. The barges release the sand in water depths of 8-10 ft (Sabine Herber, Wilmette Harbor Association, personal communication, 12 August 2015). A curved groin near the end of Linden Avenue anchors this narrow beach. The groin was built between 1999 and 2002. Google Earth Pro photographs show that the groin was almost filled in 2002, but a minor fillet at the south side emerged and disappeared over time.

Google Earth photographs show multiple sand bars, indicating active sediment transport. With northeast winds, a sand bar forms across the mouth of the harbor, while southeast winds push sand into the harbor. In the past, approximately $10 \%$ of the annual dredging was placed off Gillson Beach, but now all is moved to the south. Depending on winds and water levels, some of the sand moves onto the beach while the rest moves south in littoral transport (Sabine Herber, Wilmette Harbor Association, personal communication, 12 August 2015). The volume is assumed equal to the annual dredging, but the total longshore transport may be greater.

\section{Cell 18, Wilmette Harbor to Northwestern University}

This cell is outside of the sediment budget study area. It has been included because it receives sand from Cell 17. Much of the shore is armored without beach, but a small beach exists at the Evanston Water Treatment Plant. 


\section{Conclusions}

Chrzastowski and Trask (1996a) computed a North Illinois sediment budget for the period 1974-1995. This study continues this earlier analysis to cover the 1990 s to 2017. This sediment budget also provides a tool for decisionmakers along the North Illinois Shore to evaluate littoral processes and make sand management decisions within a regional context. Many of the sediment budget cells developed by Chrzastowski and Trask (1996a) have been retained, but some have been divided into smaller cells for more detailed information. For example, the IBSP has been divided into two cells, the northern one covering the zone of major nearshore erosion, and the southern cell with approximately neutral volume change (Figure 8).

Longshore sediment transport along the north Illinois shore is predominately from north to south. The volume in the system varies greatly. At the Wisconsin-Illinois border, sand input was assumed to be 16,000 yd3/year based on monitoring work by Chrzastowski (2003). Along the IBSP, the transport rate is approximately $190,000 \mathrm{yd} 3 /$ year primarily sourced from beach and lakebed erosion despite nearly annual placement of dredged material from the maintenance of Waukegan Harbor, North Point Marina and inland sources.

At the Waukegan Electric Generating Station, 52,000 yd3/year are removed from the cooling water canal and placed on land. The sand pile now contains approximately $620,000 \mathrm{yd}^{3}$ (Figure 11 and Figure 12). South of the station, approximately 44,200 yd3/year has accumulated in cell 6 north of the fillet beach while 5,100 yd $3 /$ year has accumulated north of the Waukegan north jetty in the fillet beach (Figure 14). The fillet may have reached capacity, resulting in an increasing amount of sand rounding the north jetty and entering the navigation approach channel.

Some sand has historically bypassed Waukegan and accumulated on the lakebed. Comparison of mid-1970s acoustic and 2012 lidar bathymetry show the lakebed accumulation volume to be approximately 27,300 yd3/year in the plume (Figure 17). Considering beach growth at the Waukegan fillet, navigation channel dredging, and lakebed accumulation south of Waukegan, littoral transport has reduced to only 11,200 yd3/year at U.S. Naval Station Great Lakes. 
The fillet at U.S. Naval Station Great Lakes has been at capacity for several decades (Chrzastowski and Trask 1996a). Less than 2,000 yd3/year enter the harbor, based on recent dredging conducted by the U.S. Navy.

Along Lake Bluff, minor retreat of the bluff has supplied limited amount of sand to the littoral budget. Farther south, the bluffs are more fully armored and protected and therefore do not supply sand to the beaches. There may be minor fine grain material coming down ravines and streams, but these volumes are unknown.

Between Forest Park Beach and Wilmette, longshore transport is only approximately 13,100 yd3/year (Figure 21).

The best available data were used for the computations in this sediment budget. However, some fluxes had to be inferred (i.e., from dredging records) and some were not considered (e.g., aeolian transport, offshore flux). Evaluating inter-annual variability in littoral sediment flux rates was beyond the scope of this study but should be included in refinement of this budget as this is important information for developing regional sand management strategies. Detailed field studies that build out from this sediment budget are needed to validate the flux rates used in this sediment budget as well as generate reasonable estimates for fluxes not included in this study. These studies will help to refine the estimates of littoral transport in this report.

An uncertainty analysis has not been conducted. Removal and placement values are the most reliable data used in this study because they are computed from barge, truck haul, or dredge volumes. Volumes based on bathymetry are less reliable because of uncertainty in the 1970s surveys and the fact that those surveys did not extend as far offshore as the contemporary lidar surveys.

Several topics will require further examination as a result of this study. The sediment input into Illinois from Wisconsin should be measured and then used to update the estimates of littoral transport put forth in this budget. Ultimately, a regional sediment budget for the west shore of Lake Michigan needs to include sediment supply and movement along both the Wisconsin and Illinois shores. The growth of the fillet beach at Waukegan could be re-examined to determine if it has reached capacity and is now promoting sand bypassing Annual beach profile surveys could be used to 
evaluate if the total sand volume in the fillet is changing or has stabilized, implying that new sand moving in from the north bypasses the beach and continues south into the Waukegan navigation channel. The littoral transport at Wilmette has been inferred based on the dredging history at the harbor; however, the piers open to the southeast, and it is likely that some sand bypasses the harbor mouth and moves south. Sand mass captured in the 2016 Google Earth aerial photographs suggest active sand bypassing; therefore, it is possible that the total sand in littoral transport is greater than the dredge volume of $12,800 \mathrm{yd} 3 /$ year. The beaches south of Wilmette Harbor and at the Evanston Water Treatment Plant could be profiled regularly to determine how much sand bypasses Wilmette. 


\section{References}

Bretz, J. H. 1955. The Geology of the Chicago Region, Part II - The Pleistocene. Bulletin No. 65, Part II. Urbana, IL: Illinois State Geological Survey, Division of the State Geological Survey.

Chrzastowski, M. J. 2003. Evaluation of 1988-2002 Lake-Bottom Changes in the Vicinity of North Point Marina. ISGS Open File Report 2003-2. Champaign, IL: Department of Natural Resources, Illinois State Geological Survey.

Chrzastowski, M. J., A. M. Foyle, and C. B. Trask. 1996. Erosion and Accretion Trends along the Lake Michigan Shore at North Point Marina and Illinois Beach State Park, Year-1 (1995) Report of a Four-Year Study of Coastal Geology and Coastal Geologic Processes. ISGS Open File Report Series 1996-1. Champaign, IL: Department of Natural Resources, Illinois State Geological Survey.

Chrzastowski, M. J., and W. T. Frankie. 2000. Guide to the Geology of Illinois Beach State Park and the Zion Beach-Ridge Plain, Lake County, Illinois. Field Trip Guidebook 200oD. Champaign, IL: Department of Natural Resources, Illinois State Geological Survey.

Chrzastowski, M. J., A. L. Erdmann, C. J. Stohr, and P. D. Terpstra. 1993. Illinois Pilot Erosion-rate Study. Final Contract Report for FEMA Assistance Award No. EMW-91-K-3575, Report 1 of 2, Open File Series 1993-3. Champaign, IL: Illinois State Geological Survey.

Chrzastowski, M. J., and C. B. Trask. 1996a. Nearshore Geology and Geologic Processes along the Illinois Shore of Lake Michigan from Waukegan Harbor to Wilmette Harbor, Contribution to the U.S. Army Corps of Engineers Illinois Shoreline Erosion Interim IV Study, Final Report. Contract No. DACW23-95-M-0143. Chicago, IL: U.S. Army Corps of Engineers.

Chrzastowski, M. J., and C. B. Trask. 1996b. Review of the City of Lake Forest Final Report for the 1995 Beach and Nearshore Monitoring Program, Forest Park Beach, Lake Forest, Illinois. Illinois State Geological Survey, Open File Series 1996-6. Champaign, IL: Illinois State Geological Survey.

Coordinating Committee on Great Lakes Basic Hydraulic and Hydrologic Data. 1992. IGLD 1985, Brochure on the International Great Lakes Datum 1985. Washington, DC: Government Printing Office.

Dopsovic, R., L. Hardegree, and J. D. Rosati. 2002. SBAS-A: SBAS for ArcView(C) Application. CHETN-XIV-7. Vicksburg, MS: U.S. Army Engineer Research and Development Center.

Foyle, A. M., and M. C. Chrzastowski. 1997. Erosion and Accretion Trends along the Lake Michigan Shore at North Point Marina and Illinois Beach State Park, Year-2 (1996) Report of a Four-Year Study of Coastal Geology and Coastal Geologic Processes. ISGS Open File Report Series 1997-8. Champaign, IL: Department of Natural Resources, Illinois State Geological Survey. 
Foyle, A. M., M. J. Chrzastowski, and C. B. Trask. 1998. Erosion and accretion trends along the Lake Michigan Shore at North Point Marina and Illinois Beach State Park, Year 3 (1997) Report of a Four-Year Study of Coastal Geology and Coastal Geologic Processes. ISGS Open File Report Series 1998-3. Champaign, IL: Department of Natural Resources, Illinois State Geological Survey.

Illinois State Geological Survey. 1988. Coastal Atlas, Illinois Shore of Lake Michigan, Revised 1987-1988. Illinois Division of Water Resources Obligation WRo8819. Champaign, IL: Illinois State Geological Survey.

Lillycrop, L. S., J. W. McCormick, L. E. Parson, and M. A. Chasten. 2011. "Adaptive Management through Regional Sediment Management." Proceedings, WEDA XXXI Technical Conference and TAMU 42 Dredging Seminar, Nashville, TN.

Lineback, J. A. 1974. "Erosion of Till Bluffs: Wilmette to Waukegan.” Coastal Geology, Sedimentology, and Management Chicago and Northshore. Edited by C. Collinson, J. A. Lineback, P. B. DuMontelle, and D. C. Brown. Illinois State Geological Survey Guidebook Series 12. Champaign, IL: Illinois State Geological Survey.

Macon, C. L. 2009. "USACE National Coastal Mapping Program and the Next Generation of Data Products.” OCEANS 2009, MTS/IEEE Biloxi - Marine Technology for Our Future: Global and Local Challenges, 1-7. http://ieeexplore.ieee.org/xpls/abs_all.jsp?arnumber $=5422169 \&$ tag $=1$

National Oceanic and Atmospheric Administration (NOAA). 1980. Establishment of International Great Lakes Datum (1955), Second Edition. Washington, DC: U.S. Government Printing Office. http://tidesandcurrents.noaa.gov/publications/Establishment_of_International_Great_Lakes_D atum_1955.pdf

North Wind. 2011a. Delivery Order Closure Report. Naval Station Great Lakes Fiscal Year 2007 Harbor Dredging, Great Lakes, IL. Contract No. N40083-05-D-4016. Report prepared for Department of the Navy, Naval Facilities Engineering Command, Engineering Field Activity Midwest. Prepared by North Wind Remediation Service.

North Wind. 2011b. Delivery Order Closure Report. Naval Station Great Lakes Fiscal Year 2008 Harbor Dredging, Great Lakes, IL. Contract No. N40083-05-D-4016. Report prepared for Department of the Navy, Naval Facilities Engineering Command, Engineering Field Activity Midwest. Prepared by North Wind Remediation Services.

North Wind. 2011c. Delivery Order Closure Report. Naval Station Great Lakes Fiscal Year 2009 Harbor Dredging, Great Lakes, IL. Contract No. N40083-05-D-4016, Delivery Order No. 006o. Report prepared for Department of the Navy, Naval Facilities Engineering Command, Engineering Field Activity Midwest, prepared by North Wind Remediation Services, Idaho Fall.

Rosati, J. D. 2005. "Concepts in Sediment Budgets.” Journal of Coastal Research 22(2): 307-322. 
Rosati, J. D., and N. Kraus. 2001. Sediment Budget Analysis System (SBAS): Upgrade for Regional Applications. ERDC/CHL CHETN-XIV-3. Vicksburg, MS: U.S. Army Engineer Research and Development Center.

Shabica, C., and F. Pranschke. 1994. "Survey of Littoral Drift Sand Deposits along the Illinois and Indiana Shores of Lake Michigan.” Journal of Great Lakes Research 20(1): 61-72.

Shabica, C. W., J. Meshberg, R. Keefe, and R. Georges. 2004. "Evolution and Performance of Groins on a Sediment Starved Coast: The Illinois Shore of Lake Michigan North of Chicago, 1880-2000.” Journal of Coastal Research Special Issue No. 33: 39-56.

Shabica, C. W., J. R. Jennings, M. Riley, and J. Boeckler. 2010. "Stabilization of Ravines, Adjacent Beaches, and Bluffs on Lake Michigan.” Shore \& Beach 78(1): 3-26.

State of Illinois Division of Waterways. 1958. Interim Report for Erosion Control Illinois Shore of Lake Michigan: State of Illinois. Springfield, IL: Department of Public Works and Buildings, Division of Waterways.

U.S. Army Corps of Engineers (USACE). 1953. Illinois Shore of Lake Michigan, Beach Erosion Control Study. 83rd U.S. Congress, 1st Session, House Doc. No 28. Washington, DC.

USACE. 1989. Illinois Shoreline Erosion Lake Michigan. Draft Feasibility Report. Interim IV Waukegan to Wilmette. Department of the Army, Chicago District. Chicago, IL: USACE.

USACE. 2014. Illinois Beach State Park, Lake County, Illinois Section 204 Beneficial Use of Dredged Material Detailed Project Report/ Regional Sediment Management Plan and Environmental Assessment. Chicago, IL: Department of the Army, Chicago District, Corps of Engineers.

Wozencraft, J. M., and D. Millar. 2005. "Airborne Lidar and Integrated Technologies for Coastal Mapping and Charting." Marine Technology Society Journal 39(3): 2735 .

Wozencraft, J. M., and W. J. Lillycrop. 2006. "JALBTCX Coastal Mapping for the USACE.” International Hydrographic Review 7(2): 28-37. 


\section{Appendix A: Data Used for Computing 1970s- 2017 Sediment Budget}

Table A-1 tabulates the data used in this study to compute the 1970s-2017 sediment budget. The nomenclature is the same used in the USACE SBAS software (used to plot the fluxes and cell volumes in the figures in the body of this report). The SBAS project files will be available for future users, but Table A-1 contains the same data.

Table A-1. Sediment Budget, north Illinois.

\begin{tabular}{|l|}
\hline Nomenclature \\
\hline Units: $y d^{3} /$ year \\
\hline Source 1 = bluffs, river influx, wind \\
\hline Sink 1 = wind-blown loss or other \\
\hline Source or sink 2 = offshore \\
\hline Source or sink 3 = other (inlet, channel, trap, harbor) \\
\hline LST1 = right (N) side of cell viewed from offshore \\
\hline LST2 = left (S) side of cell viewed from offshore \\
\hline Yellow = coastal cell \\
\hline Purple = harbor cell \\
\hline
\end{tabular}

\begin{tabular}{|l|l|l|l|}
\hline Cell (North-South) & Variable & $\begin{array}{l}\text { Budget } \\
1990 s- \\
2017\end{array}$ & Notes, source \\
\hline
\end{tabular}

\begin{tabular}{|l|l|l|l|}
\hline Cell WI-1 & Qsource1 & & \\
\hline Kenosha to WI border & Qsink1 & & \\
\hline $\begin{array}{l}\text { (placeholder - no data } \\
\text { examined for this region) }\end{array}$ & Qsource2 & & \\
\hline & Qsink2 & & \\
\hline & Qsource3 & & \\
\hline & Qsink3 & & \\
\hline & $\begin{array}{l}\text { Qsource- } \\
\text { LST1 }\end{array}$ & & \\
\hline & Qsink-LST1 & & \\
\hline
\end{tabular}




\begin{tabular}{|l|l|l|l|}
\hline & $\begin{array}{l}\text { Qsource- } \\
\text { LST2 }\end{array}$ & & \\
\hline & Qsink-LST2 & 16,000 & South to Cell 1 \\
\hline & Placement & & \\
\hline & Removal & & \\
\hline & DeltaV & & \\
\hline & Residual & $-16,000$ & \\
\hline
\end{tabular}

\begin{tabular}{|c|c|c|c|}
\hline Cell 1 & Qsource1 & & \\
\hline \multirow{14}{*}{$\begin{array}{l}\text { North Point Marina, } \\
\text { built 1987-88 }\end{array}$} & Qsink1 & & \\
\hline & Qsource2 & & \\
\hline & Qsink2 & & \\
\hline & Qsource3 & & \\
\hline & Qsink3 & & \\
\hline & $\begin{array}{l}\text { Qsource- } \\
\text { LST1 }\end{array}$ & 16,000 & From north \\
\hline & Qsink-LST1 & & \\
\hline & $\begin{array}{l}\text { Qsource- } \\
\text { LST2 }\end{array}$ & & \\
\hline & Qsink-LST2 & 20,400 & To Cell 2 \\
\hline & Placement & 9,400 & $\begin{array}{l}\text { Sand imported to form feeder beach, } \\
\text { Chrzastowski et al. (1996, p. 17). }\end{array}$ \\
\hline & Removal & 9,600 & Annual dredge from David Suthard, 8/21/14 \\
\hline & Removal & 0 & \\
\hline & DeltaV & $-4,600$ & Compare $1976-2012$ bathy \\
\hline & Residual & 0 & \\
\hline
\end{tabular}

\begin{tabular}{|l|l|l|l|}
\hline Cell 2 & Qsource1 & & \\
\hline IL Beach State Park N & Qsink1 & & \\
\hline & Qsource2 & & \\
\hline & Qsink2 & & \\
\hline & Qsource3 & & \\
\hline & Qsink3 & & \\
\hline & $\begin{array}{l}\text { Qsource- } \\
\text { LST1 }\end{array}$ & 20,400 & From north, Cell 1 \\
\hline & Qsink-LST1 & & \\
\hline
\end{tabular}




\begin{tabular}{|l|l|l|l|}
\hline & $\begin{array}{l}\text { Qsource- } \\
\text { LST2 }\end{array}$ & & \\
\hline & Qsink-LST2 & 188,300 & To Cell 3 \\
\hline & Placement & 9,600 & Bypassed from North Point Marina \\
\hline & Placement & 27,000 & Backpassed from Waukegan \\
\hline & Removal & & \\
\hline & DeltaV & $-131,300$ & Compare 1976-2012 bathy \\
\hline & Residual & 0 & \\
\hline
\end{tabular}

\begin{tabular}{|l|l|l|l|}
\hline Cell 3 & Qsource1 & & \\
\hline \multirow{3}{*}{$\begin{array}{l}\text { IBSP S unit to Waukegan } \\
\text { Electric Generating Station }\end{array}$} & Qsink1 & & \\
\cline { 2 - 4 } & Qsource2 & & \\
\hline & Qsink2 & & \\
\hline & Qsource3 & & \\
\hline & Qsink3 & 52,000 & To canal, Cell 4 \\
\hline & $\begin{array}{l}\text { Qsource- } \\
\text { LST1 }\end{array}$ & 188,300 & From Cell 2 \\
\hline & Qsink-LST1 & & \\
\hline & $\begin{array}{l}\text { Qsource- } \\
\text { LST2 }\end{array}$ & 0 & \\
\hline & Qsink-LST2 & 167,700 & To Canal, Cell 4 \\
\hline & Placement & & \\
\hline & Placement & 0 & Assume no placement from canal dredging \\
\hline & Removal & & \\
\hline & DeltaV & 20,600 & Compare 1976-2012 bathy \\
\hline & Residual & 0 & \\
\hline & & &
\end{tabular}

\begin{tabular}{|l|l|l|l|}
\hline Cell 4 & Qsource1 & & \\
\hline \multirow{5}{*}{$\begin{array}{l}\text { Waukegan Electric } \\
\text { Generating Station }\end{array}$} & Qsink1 & & \\
\cline { 2 - 4 } & Qsource2 & 52,000 & $\begin{array}{l}\text { Dredged from canal 1995-2014 (Fred } \\
\text { Veenbaas, 2/5/15) }\end{array}$ \\
\cline { 2 - 4 } & Qsink2 & & \\
\hline & Qsource3 & 0 & \\
\hline & Qsink3 & & \\
\hline & $\begin{array}{l}\text { Qsource- } \\
\text { LST1 }\end{array}$ & & \\
\hline
\end{tabular}




\begin{tabular}{|l|l|l|l|}
\hline & Qsink-LST1 & & \\
\hline $\begin{array}{l}\text { Qsource- } \\
\text { LST2 }\end{array}$ & & \\
\hline Qsink-LST2 & & \\
\hline & Placement & & \\
\hline & Removal & 52,000 & All placed on sand pile \\
\hline & DeltaV & 0 & \\
\hline & Residual & 0 & \\
\hline
\end{tabular}

\begin{tabular}{|c|c|c|c|}
\hline Cell 5 & Qsource1 & & \\
\hline \multirow{13}{*}{$\begin{array}{l}\text { Sand pile } \\
\text { Waukegan Electric } \\
\text { Generating Station } \\
\text { (on land) }\end{array}$} & Qsink1 & 11,000 & Assume wind loss. Needed to balance cell. \\
\hline & Qsource2 & & \\
\hline & Qsink2 & 10,000 & Assume compaction during drying \\
\hline & Qsource3 & & \\
\hline & Qsink3 & & \\
\hline & $\begin{array}{l}\text { Qsource- } \\
\text { LST1 }\end{array}$ & & \\
\hline & Qsink-LST1 & & \\
\hline & $\begin{array}{l}\text { Qsource- } \\
\text { LST2 }\end{array}$ & & \\
\hline & Qsink-LST2 & & \\
\hline & Placement & 52,000 & $\begin{array}{l}\text { Annual placement from canal; Fredrick } \\
\text { Veenbaas (NRG Energy) (847) 662-6201 or } \\
\text { Fredrick.veenbaas@NRGenergy.com }\end{array}$ \\
\hline & Removal & 0 & \\
\hline & DeltaV & 31,000 & $620,000 / 20$ years \\
\hline & Residual & 0 & \\
\hline
\end{tabular}

\begin{tabular}{|l|l|l|l|}
\hline Cell 6 & Qsource1 & & \\
\hline $\begin{array}{l}\text { Waukegan Elec. Generating } \\
\text { Station to Waukegan Harbor } \\
\text { beach fillet }\end{array}$ & Qsink1 & & \\
\cline { 2 - 4 } & Qsource2 & & \\
\hline & Qsink2 & & \\
\hline & Qsource3 & & \\
\hline & Qsink3 & & \\
\hline & $\begin{array}{l}\text { Qsource- } \\
\text { LST1 }\end{array}$ & 115,700 & From Cell 5 \\
\hline
\end{tabular}




\begin{tabular}{|l|l|l|l|}
\hline & Qsink-LST1 & & \\
\hline & $\begin{array}{l}\text { Qsource- } \\
\text { LST2 }\end{array}$ & & \\
\hline & Qsink-LST2 & 71,500 & To Cell 7 \\
\hline & Placement & & \\
\hline & Removal & & \\
\hline & DeltaV & 44,200 & Compare 1976-2012 bathy \\
\hline & Residual & 0 & \\
\hline
\end{tabular}

\begin{tabular}{|l|l|l|l|}
\hline Cell 7 & Qsource1 & & \\
\hline \multirow{2}{*}{$\begin{array}{l}\text { Waukegan Harbor Beach } \\
\text { Fillet to Waukegan N. Jetty }\end{array}$} & Qsink1 & & \\
\hline & Qsource2 & & \\
\hline & Qsink2 & & \\
\hline & Qsource3 & & \\
\hline & Qsink3 & & \\
\hline & $\begin{array}{l}\text { Qsource- } \\
\text { LST1 }\end{array}$ & 71,500 & From Cell 6 \\
\hline & Qsink-LST1 & & \\
\hline & $\begin{array}{l}\text { Qsource- } \\
\text { LST2 }\end{array}$ & & \\
\hline & Qsink-LST2 & 66,400 & To Cell 8 \\
\hline & Placement & & \\
\hline & Removal & & \\
\hline & DeltaV & 5,100 & Compare 1976-2012 bathy \\
\hline & Residual & 0 & \\
\hline
\end{tabular}

\begin{tabular}{|l|l|l|l|}
\hline Cell 8 & Qsource1 & & \\
\hline Waukegan Harbor & Qsink1 & & \\
\hline & Qsource2 & & \\
\hline & Qsink2 & & \\
\hline & Qsource3 & & \\
\hline & Qsink3 & & \\
\hline & $\begin{array}{l}\text { Qsource- } \\
\text { LST1 }\end{array}$ & 66,400 & Bypass and dredging total \\
\hline & Qsink-LST1 & & \\
\hline
\end{tabular}




\begin{tabular}{|l|l|c|l|}
\hline & $\begin{array}{l}\text { Qsource- } \\
\text { LST2 }\end{array}$ & \\
\hline & Qsink-LST2 & 22,600 & To sand tongue S of jetties \\
\hline & Placement & & \\
\hline & Removal & 43,800 & LRC spreadsheet 1995-2013 \\
\hline & DeltaV & 0 & \\
\hline & Residual & 0 & \\
\hline
\end{tabular}

\begin{tabular}{|l|l|l|l|}
\hline Cell 9 & Qsource1 & & \\
\hline \multirow{2}{*}{ Waukegan to N. Chicago } & Qsink1 & & \\
\hline & Qsource2 & & \\
\hline & Qsink2 & & \\
\hline & Qsource3 & & \\
\hline & Qsink3 & & \\
\hline & $\begin{array}{l}\text { Qsource- } \\
\text { LST1 }\end{array}$ & 22,600 & \\
\hline & Qsink-LST1 & & \\
\hline & $\begin{array}{l}\text { Qsource- } \\
\text { LST2 }\end{array}$ & & \\
\hline & Qsink-LST2 & 12,200 & To Cell 10 \\
\hline & Placement & 16,800 & From Waukegan dredging \\
\hline & Removal & & \\
\hline & DeltaV & 27,300 & $\begin{array}{l}\text { Based on 1975-2012 lakebed volume } \\
\text { change sand }\end{array}$ \\
\hline & Residual & 0 & \\
\hline & &
\end{tabular}

\begin{tabular}{|l|l|l|l|}
\hline Cell 10 & Qsource1 & & \\
\hline \multirow{2}{*}{ Great Lakes, N. fillet } & Qsink1 & & \\
\hline & Qsource2 & & \\
\hline & Qsink2 & & \\
\hline & Qsource3 & & \\
\hline & Qsink3 & 1,700 & Based on dredging in harbor \\
\hline & $\begin{array}{l}\text { Qsource- } \\
\text { LST1 }\end{array}$ & 12,200 & From Cell 9 \\
\hline & Qsink-LST1 & & \\
\hline
\end{tabular}




\begin{tabular}{|l|l|c|l|}
\hline & $\begin{array}{l}\text { Qsource- } \\
\text { LST2 }\end{array}$ & & \\
\hline & Qsink-LST2 & 12,800 & To Cell 11 \\
\hline & Placement & & \\
\hline & Removal & & \\
\hline & DeltaV & -100 & $\begin{array}{l}\text { Reached capacity (Chrzastowski and Trask } \\
{[1996], \text { p. 73) }}\end{array}$ \\
\hline & Residual & 0 & \\
\hline
\end{tabular}

\begin{tabular}{|l|l|l|l|}
\hline Cell 11 & Qsource1 & & \\
\hline \multirow{2}{*}{$\begin{array}{l}\text { Great Lakes Naval Station } \\
\text { Harbor }\end{array}$} & Qsink1 & & \\
\hline & Qsource2 & 1,700 & Minor input from open coast \\
\hline & Qsink2 & & \\
\hline & Qsource3 & & \\
\hline & Qsink3 & & \\
\hline & $\begin{array}{l}\text { Qsource- } \\
\text { LST1 }\end{array}$ & & \\
\hline & Qsink-LST1 & & \\
\hline & $\begin{array}{l}\text { Qsource- } \\
\text { LST2 }\end{array}$ & & \\
\hline & Qsink-LST2 & & \\
\hline & Placement & & \\
\hline & Removal & 1,700 & $\begin{array}{l}\text { 2009-2011 Closure Reports NAVFAC, based } \\
\text { on 40-year interval }\end{array}$ \\
\hline & DeltaV & 0 & Assume no more accumulation in harbor \\
\hline & Residual & 0 & \\
\hline & & & \\
\hline
\end{tabular}

\begin{tabular}{|l|l|l|l|}
\hline Cell 12 & Qsource1 & & \\
\hline \multirow{3}{*}{ Great Lakes to Lake Forest } & Qsink1 & & \\
\cline { 2 - 4 } & Qsource2 & & \\
\hline & Qsink2 & & \\
\hline & Qsource3 & & \\
\hline & Qsink3 & & \\
\hline & $\begin{array}{l}\text { Qsource- } \\
\text { LST1 }\end{array}$ & 11,200 & Assume bypass from N. fillet Cells_11 \\
\hline & Qsink-LST1 & & \\
\hline
\end{tabular}




\begin{tabular}{|l|l|l|l|}
\hline & $\begin{array}{l}\text { Qsource- } \\
\text { LST2 }\end{array}$ & & \\
\hline & Qsink-LST2 & 13,000 & To Cell 13 \\
\hline & Placement & & \\
\hline & Removal & & \\
\hline & DeltaV & $-1,800$ & $\begin{array}{l}\text { Based on 5\% sand and 1976-2012 lakebed } \\
\text { volume change }\end{array}$ \\
\hline & Residual & 0 & \\
\hline
\end{tabular}

\begin{tabular}{|l|l|c|l|}
\hline Cell 13 & Qsource1 & 0 & Bluff armored (Chrz. and Trask [1996], p. 73) \\
\hline \multirow{2}{*}{$\begin{array}{l}\text { Lake Forest (Forest Park } \\
\text { Beach) }\end{array}$} & Qsink1 & & \\
\hline & Qsource2 & & \\
\hline & Qsink2 & & \\
\hline & Qsource3 & & \\
\hline & Qsink3 & & \\
\hline & $\begin{array}{l}\text { Qsource- } \\
\text { LST1 }\end{array}$ & 13,000 & From Cell 12 \\
\hline & Qsink-LST1 & & \\
\hline & $\begin{array}{l}\text { Qsource- } \\
\text { LST2 }\end{array}$ & & \\
\hline & Qsink-LST2 & 10,500 & To Cell 14 \\
\hline & Placement & & \\
\hline & Removal & 2,600 & $\begin{array}{l}\text { From boat ramp (Mr. Rich Paulson, City of } \\
\text { Lake Forest, 2/11/15) }\end{array}$ \\
\hline & DeltaV & -100 & No significant areas loss/gain \\
\hline & Residual & 0 & \\
\hline & & &
\end{tabular}

\begin{tabular}{|l|l|c|l|}
\hline Cell 14 & Qsource1 & 0 & Negligible retreat (compare lidar to ISGS) \\
\hline \multirow{3}{*}{$\begin{array}{l}\text { Lake Forest to Winnetka } \\
\text { Power Plant, 4,600 ft long }\end{array}$} & Qsink1 & & \\
\cline { 2 - 4 } & Qsource2 & & \\
\hline & Qsink2 & & \\
\hline & Qsource3 & & \\
\hline & Qsink3 & & \\
\hline & $\begin{array}{l}\text { Qsource- } \\
\text { LST1 }\end{array}$ & 10,500 & \\
\hline & Qsink-LST1 & & \\
\hline
\end{tabular}




\begin{tabular}{|l|l|c|l|}
\hline & $\begin{array}{l}\text { Qsource- } \\
\text { LST2 }\end{array}$ & & \\
\hline & Qsink-LST2 & 13,100 & To Cell 15 \\
\hline & Placement & 2,600 & $\begin{array}{l}\text { From Lake Forest Park boat ramp (Mr. Rich } \\
\text { Paulson, City of Lake Forest, 2/11/15) }\end{array}$ \\
\hline & Removal & & \\
\hline & DeltaV & 0 & \\
\hline & Residual & 0 & \\
\hline
\end{tabular}

\begin{tabular}{|c|c|c|c|}
\hline Cell 15 & Qsource1 & 0 & $\begin{array}{l}\text { Bluff armored (Chrzastowski and Trask } \\
\text { [1996], p. 73) }\end{array}$ \\
\hline \multirow{13}{*}{$\begin{array}{l}\text { Winnetka Power Plant to } \\
\text { Langdon Park }\end{array}$} & Qsink1 & & \\
\hline & Qsource2 & & \\
\hline & Qsink2 & & \\
\hline & Qsource3 & & \\
\hline & Qsink3 & & \\
\hline & $\begin{array}{l}\text { Qsource- } \\
\text { LST1 }\end{array}$ & 13,100 & \\
\hline & Qsink-LST1 & & \\
\hline & $\begin{array}{l}\text { Qsource- } \\
\text { LST2 }\end{array}$ & & \\
\hline & Qsink-LST2 & 13,100 & To Gillson Park \\
\hline & Placement & & \\
\hline & Removal & & \\
\hline & DeltaV & & \\
\hline & Residual & 0 & \\
\hline
\end{tabular}

\begin{tabular}{|l|l|l|l|}
\hline Cell 16 & Qsource1 & 0 & $\begin{array}{l}\text { Bluff armored (Chrzastowski and Trask } \\
{[1996], \text { p. 73) }}\end{array}$ \\
\hline Gillson Park & Qsink1 & & \\
\hline & Qsource2 & & \\
\hline & Qsink2 & & \\
\hline & Qsource3 & & \\
\hline & Qsink3 & & \\
\hline & $\begin{array}{l}\text { Qsource- } \\
\text { LST1 }\end{array}$ & 13,100 & Assume equal to dredge volume \\
\hline & Qsink-LST1 & & \\
\hline
\end{tabular}




\begin{tabular}{|l|l|l|l|}
\hline & $\begin{array}{l}\text { Qsource- } \\
\text { LST2 }\end{array}$ & & \\
\hline & Qsink-LST2 & 13,100 & \\
\hline & Placement & & \\
\hline & Removal & & \\
\hline & DeltaV & & \\
\hline & Residual & 0 & \\
\hline
\end{tabular}

\begin{tabular}{|c|c|c|c|}
\hline Cell 17 & Qsource1 & & \\
\hline \multirow[t]{13}{*}{$\begin{array}{l}\text { Wilmette Harbor and S. } \\
\text { beach }\end{array}$} & Qsink1 & & \\
\hline & Qsource2 & & \\
\hline & Qsink2 & & \\
\hline & Qsource3 & & \\
\hline & Qsink3 & & \\
\hline & $\begin{array}{l}\text { Qsource- } \\
\text { LST1 }\end{array}$ & 13,100 & \\
\hline & Qsink-LST1 & & \\
\hline & $\begin{array}{l}\text { Qsource- } \\
\text { LST2 }\end{array}$ & & \\
\hline & Qsink-LST2 & 13,100 & Assume all moves south \\
\hline & Placement & 12,800 & Placement offshore of beach to south \\
\hline & Removal & 12,800 & $\begin{array}{l}\text { 1998-2015, Sabine Herber, Executive } \\
\text { Director, Wilmette Harbor Association }\end{array}$ \\
\hline & DeltaV & & \\
\hline & Residual & 0 & \\
\hline
\end{tabular}

\begin{tabular}{|l|l|l|l|}
\hline Cell 18 & Qsource1 & & No data \\
\hline $\begin{array}{l}\text { Wilmette S. beach to } \\
\text { Northwestern University }\end{array}$ & Qsink1 & & No data \\
\hline & Qsource2 & & No data \\
\hline & Qsink2 & & No data \\
\hline & Qsource3 & & No data \\
\hline & Qsink3 & & No data \\
\hline & $\begin{array}{l}\text { Qsource- } \\
\text { LST1 }\end{array}$ & 13,100 & \\
\hline & Qsink-LST1 & & No data \\
\hline
\end{tabular}




\begin{tabular}{|l|l|l|l|}
\hline & $\begin{array}{l}\text { Qsource- } \\
\text { LST2 }\end{array}$ & No data \\
\hline & Qsink-LST2 & 13,100 & \\
\hline & Placement & & No data \\
\hline & Removal & & No data \\
\hline & DeltaV & & No data \\
\hline & Residual & 13,000 & \\
\hline
\end{tabular}




\section{Appendix B: Elevation and Volume Change for Northern Illinois Coastline, 2008-2012}

The USACE NCMP surveyed the northern Illinois coastline during the summers of 2008 and 2012. The standard NCMP $1 \mathrm{~m}$ grid products were used for the analysis since the grids are generated to ensure cells are snapped and offsets in the cell placement are removed. Both lidar datasets were projected in feet, NAVD88, and horizontal datum of NAD83 Illinois State Plane east zone, FIPS 1201.

An initial elevation difference comparison of the two datasets showed some unrealistic accumulation in the offshore area near Waukegan Harbor. Profiles were extracted from both datasets at a 1,000 ft spacing to determine the mean offset between the profiles. The majority of the profiles had a mean offset of $0.3 \mathrm{ft}$ whereas in the 5 -mile stretch near Waukegan Harbor the mean offset was $0.8 \mathrm{ft}$. To remove the bias as a result of this mean offset, the 2008 bathymetric data in the 5 -mile stretch near Waukegan Harbor were shifted by $0.8 \mathrm{ft}$.

The 2012 and 2008 lidar datasets were differenced to determine elevation change. Bins that were spaced at $1,000 \mathrm{ft}$ were generated to calculate the volume change. The volume change was determined by summing the cells for erosion, accretion, and net volume change. The results from the elevation and volume change comparison are provided in Figure B-1 through Figure B-4. Each map shows the elevation change comparison between the 2012 and 2008 datasets with areas of accretion displayed as green and areas of erosion displayed as purple. The bar chart provides the volume in cubic yards within each of the bins. The table at the bottom of the map provides the numeric value for the respective bin for erosion, accretion, and net volume change. 
Figure B-1. Elevation and volume change for box 1 of northern Illinois coastline.

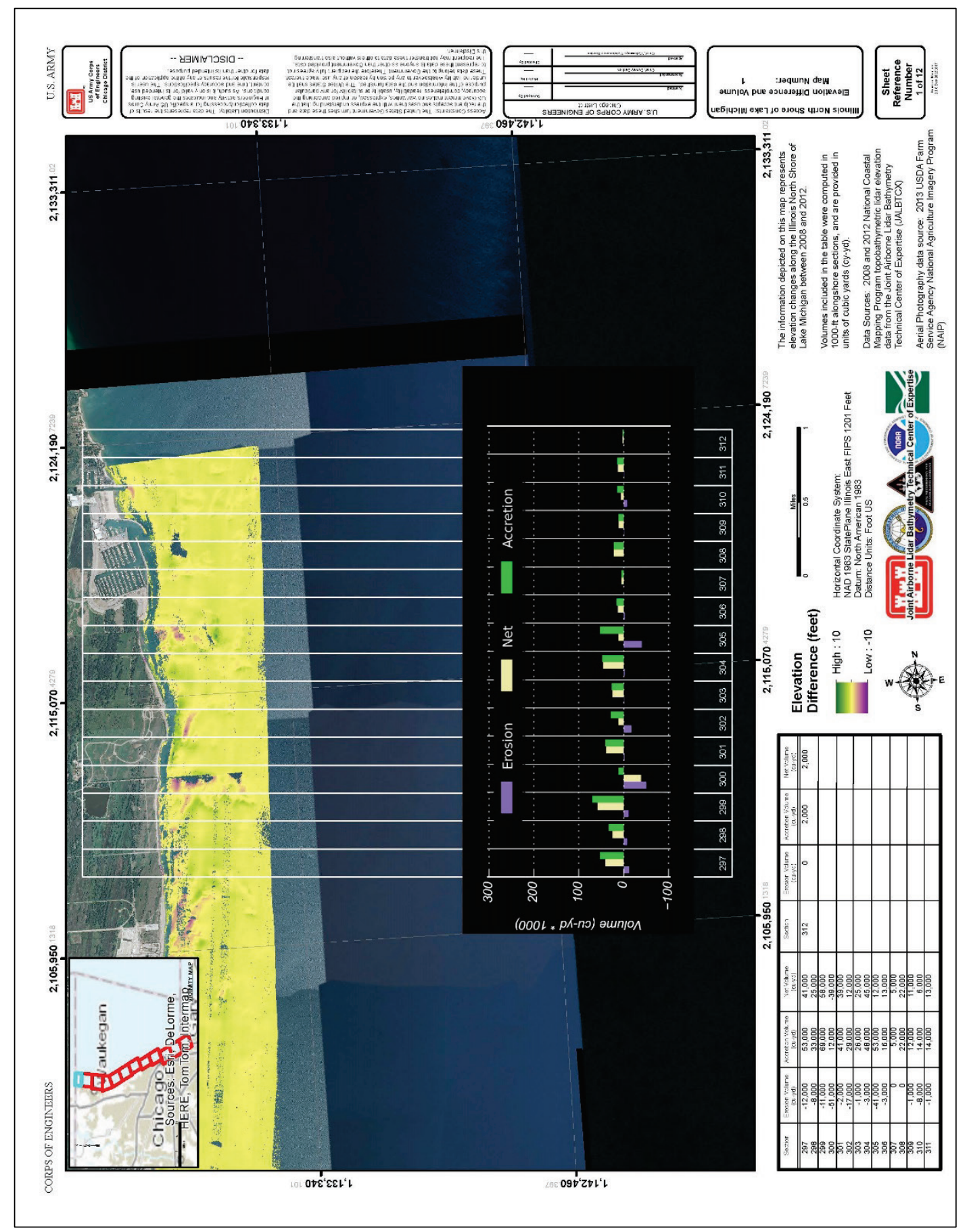


Figure B-2. Elevation and volume change for box 2 of northern Illinois coastline.

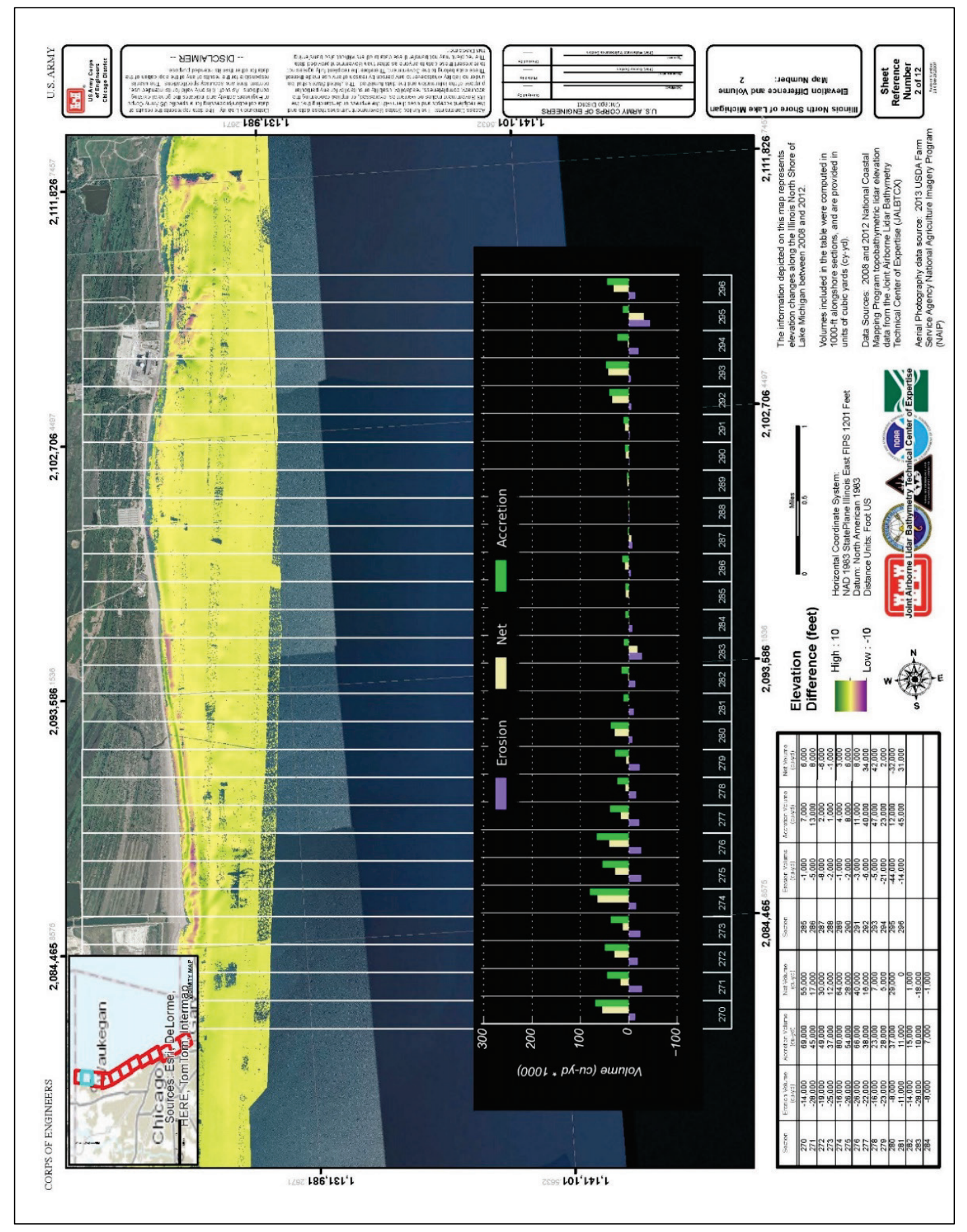


Figure B-3. Elevation and volume change for box 3 of northern Illinois coastline.

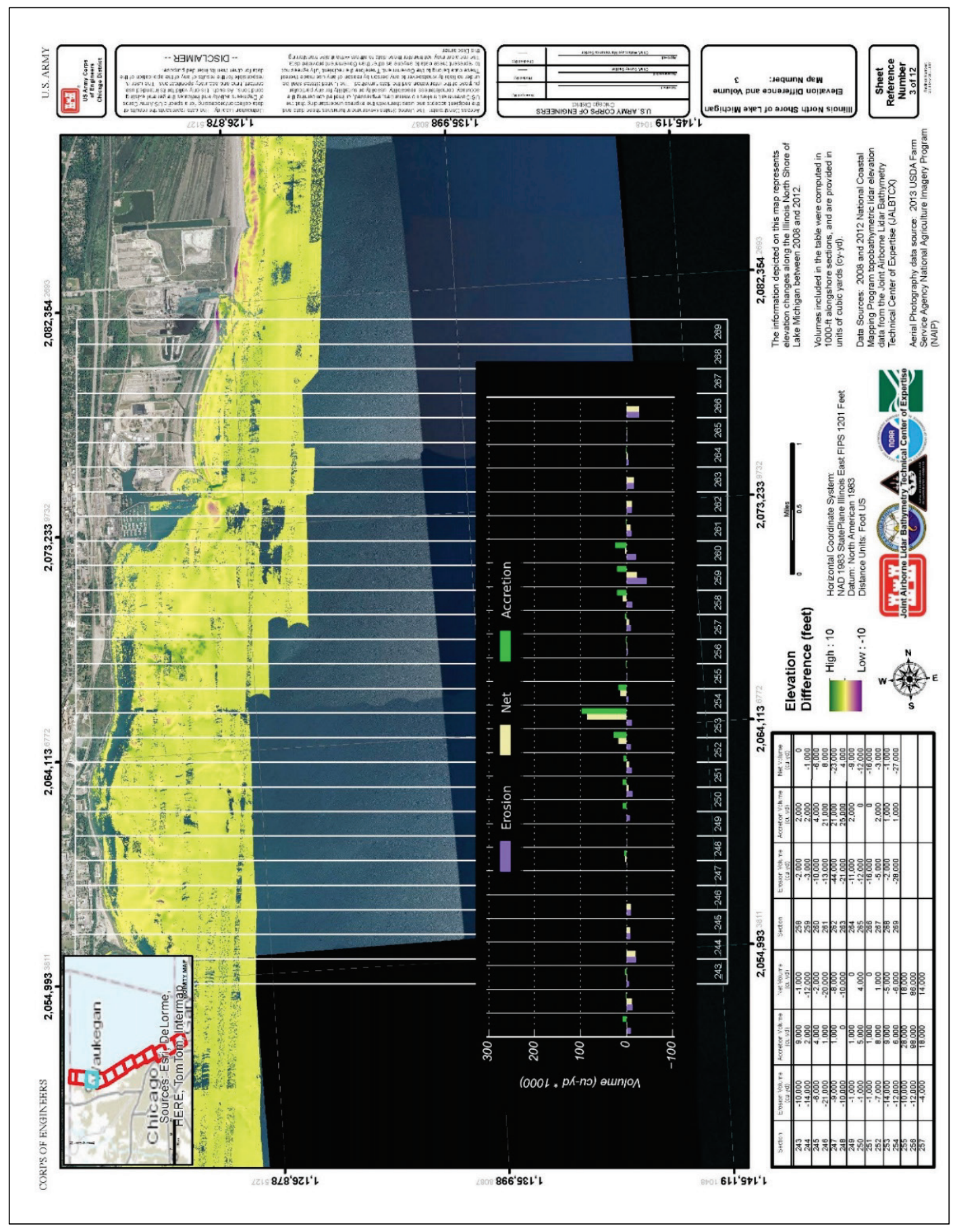


Figure B-4. Elevation and volume change for box 4 of northern Illinois coastline.

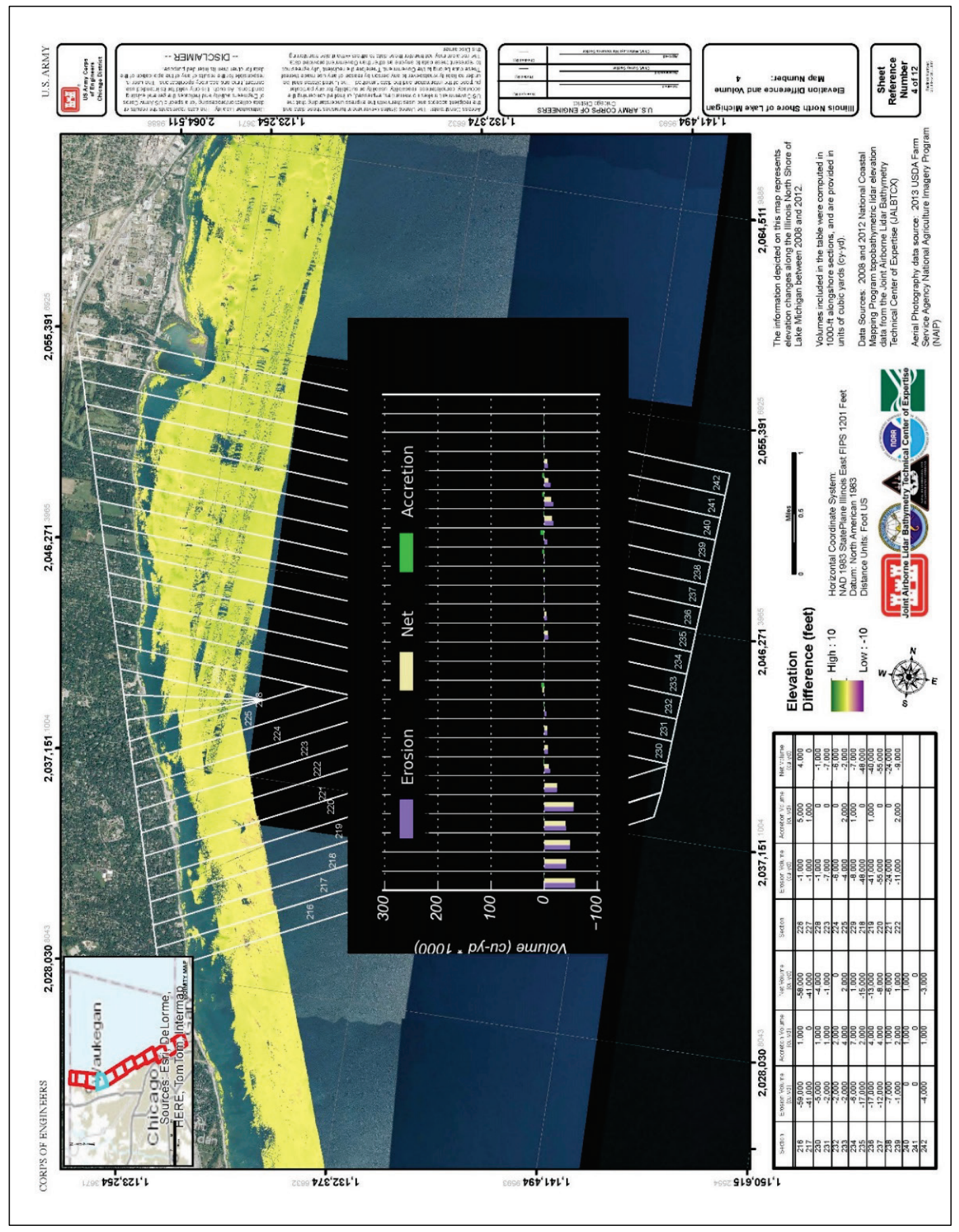




\section{Unit Conversion Factors}

\begin{tabular}{|l|c|l|}
\hline Multiply & By & To Obtain \\
\hline feet & 0.3048 & meters \\
\hline miles (U.S. statute) & $1,609.347$ & meters \\
\hline tons (2,000 pounds mass) & 907.1847 & kilograms \\
\hline
\end{tabular}




\begin{tabular}{|c|c|c|c|c|c|}
\hline \multicolumn{5}{|c|}{ REPORT DOCUMENTATION PAGE } & $\begin{array}{c}\text { Form Approved } \\
\text { OMB No. 0704-0188 }\end{array}$ \\
\hline \multicolumn{6}{|c|}{ 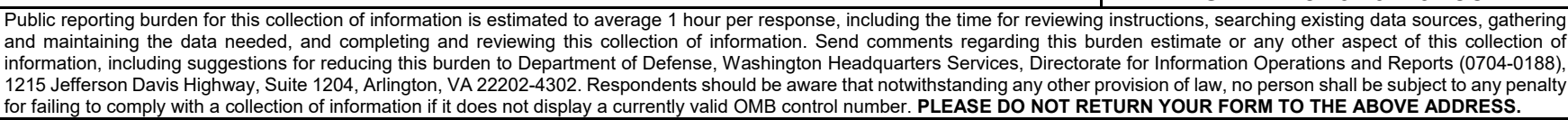 } \\
\hline \multicolumn{2}{|c|}{$\begin{array}{l}\text { 1. REPORT DATE (DD-MM-YYYY) } \\
\text { August } 2019\end{array}$} & \multicolumn{3}{|c|}{$\begin{array}{l}\text { 2. REPORT TYPE } \\
\text { Final }\end{array}$} & 3. DATES COVERED (From - To) \\
\hline \multirow{3}{*}{\multicolumn{5}{|c|}{$\begin{array}{l}\text { 4. TITLE AND SUBTITLE } \\
\text { Sediment Budget for the North Illinois Shore from the Wisconsin Border to Wilmette } \\
\text { Harbor }\end{array}$}} & 5a. CONTRACT NUMBER \\
\hline & & & & & 5b. GRANT NUMBER \\
\hline & & & & & 5c. PROGRAM ELEMENT NUMBER \\
\hline \multirow{3}{*}{\multicolumn{5}{|c|}{$\begin{array}{l}\text { 6. AUTHOR(S) } \\
\text { Andrew Morang, Lauren M. Dunkin, David F. Bucaro, John A. Wethington, } \\
\text { Michael J. Chrzastowski, and Ethan J. Theuerkauf }\end{array}$}} & 5d. PROJECT NUMBER \\
\hline & & & & & 5e. TASK NUMBER \\
\hline & & & & & 5f. WORK UNIT NUMBER \\
\hline \multirow{2}{*}{\multicolumn{5}{|c|}{ 7. PERFORMING ORGANIZATION NAME(S) AND ADDRESS(ES) (see reverse) }} & $\begin{array}{l}\text { 8. PERFORMING ORGANIZATION } \\
\text { REPORT }\end{array}$ \\
\hline & & & & & ERDC/CHL TR-19-13 \\
\hline \multirow{2}{*}{\multicolumn{5}{|c|}{$\begin{array}{l}\text { 9. SPONSORING / MONITORING AGENCY NAME(S) AND ADDRESS(ES) } \\
\text { U.S. Army Corps of Engineers } \\
\text { Washington, DC 20314-1000 }\end{array}$}} & $\begin{array}{l}\text { 10. SPONSOR/MONITOR'S } \\
\text { ACRONYM(S) } \\
\text { USACE }\end{array}$ \\
\hline & & & & & $\begin{array}{l}\text { 11. SPONSOR/MONITOR'S REPORT } \\
\text { NUMBER(S) }\end{array}$ \\
\hline \multicolumn{6}{|c|}{ 12. DISTRIBUTION / AVAILABILITY STATEMENT } \\
\hline \multicolumn{6}{|c|}{ Approved for public release; distribution is unlimited. } \\
\hline \multicolumn{6}{|c|}{$\begin{array}{l}\text { 13. SUPPLEMENTARY NOTES } \\
\text { Funding Account Code U4362913; AMSCO Code } 008303\end{array}$} \\
\hline \multicolumn{6}{|c|}{$\begin{array}{l}\text { 14. ABSTRACT } \\
\text { A sediment budget for the North Illinois Shore was developed to evaluate littoral processes and provide a regional sand } \\
\text { management decision support tool. This study time frame covers the } 1990 \text { s to } 2017 \text {. The North Shore of Illinois is a highly } \\
\text { dynamic and diverse coastline with littoral processes complicated by coastal infrastructure, commercial harbors, and } \\
\text { uncoordinated shoreline management. Longshore sediment transport along the North Illinois Shore is predominately from } \\
\text { north to south, and the volume in the system varies greatly. The best available data were used for the computations in this } \\
\text { sediment budget. However, some fluxes had to be inferred (i.e., from dredging records), and some were not considered (i.e., } \\
\text { aeolian transport, offshore flux). }\end{array}$} \\
\hline \multicolumn{6}{|c|}{$\begin{array}{l}\text { 15. SUBJECT TERMS } \\
\text { Coast changes, Littoral drift, Michigan, Lake, Coast (Ill.), Michigan, Lake, Coast (Wis.), Sedimentation and deposition, } \\
\text { Sediment control, Sediment transport, Shorelines }\end{array}$} \\
\hline \multicolumn{3}{|c|}{ 16. SECURITY CLASSIFICATION OF: } & $\begin{array}{l}\text { 17. LIMITATION } \\
\text { OF ABSTRACT }\end{array}$ & $\begin{array}{l}\text { 18. NUMBER } \\
\text { OF PAGES }\end{array}$ & $\begin{array}{l}\text { 19a. NAME OF RESPONSIBLE PERSON } \\
\text { Lauren M. Dunkin }\end{array}$ \\
\hline $\begin{array}{l}\text { a. REPORT } \\
\text { Unclassified }\end{array}$ & $\begin{array}{l}\text { b. ABSTRACT } \\
\text { Unclassified }\end{array}$ & $\begin{array}{l}\text { c. THIS PAGE } \\
\text { Unclassified }\end{array}$ & SAR & 83 & $\begin{array}{l}\text { 19b. TELEPHONE NUMBER (include area } \\
\text { code) } \\
601-634-5138\end{array}$ \\
\hline
\end{tabular}


Coastal and Hydraulics Laboratory

U.S. Army Engineer Research and Development Center 3909 Halls Ferry Road

Vicksburg, MS 39180-6199

U.S. Army Engineer District, Chicago

111 North Canal Street

Chicago, IL 60606-7206

Illinois State Geological Survey

615 East Peabody Drive

Champaign, IL 61820-6918 